\title{
VERHANDELINGEI
}

VAN HET KONINKLIJK INSTITUUT VOOR

TAAL-, LAND- EN VOLKENKUNDE

DEEL 47

H. K. J. COWAN

\section{GRAMMAR OF THE SENTANI \\ LANGUAGE}

WITH SPECIMEN TEXTS AND VOCABULARY

'S-GRAVENHAGE-MARTINUS N IJHOFF- 1965

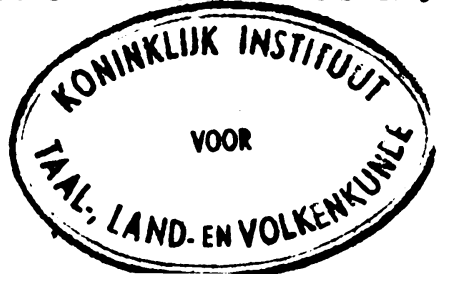



GRAMMAR OF THE SENTANI LANGUAGE 


\section{TO THE MEMORY OF MY YOUNGER SON}

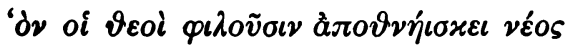




\section{CONTENTS}

I. INTRODUCTION . . . . . . page

I. 1. Litterature . . . . . . . . . . . . . 1

I. 2 . Area and relations . . . . . . . . . . 1

II. PHONOLOGY . . . . . . . . . . . . . . . 3

II. 1. General remarks . . . . . . . . . . . 3

II. 2. Vowels . . . . . . . . . . . . . . 4

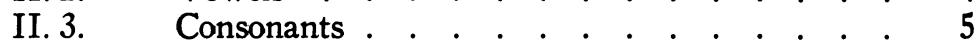

II. 4. Phonemic structure of the word . . . . . . 8

II. 4. 1. Stress . . . . . . . . . . . . . . . 9

III. MORPHOLOGY . . . . . . . . . . . . . . . 11

III. 1. Morphological structure of the word . . . . 11

III. 2. Derivation, (1) repetition . . . . . . . . 11

III. 2. 1. Derivation, (2) composition . . . . . . . 12

III. 2. 2. Borderline cases . . . . . . . . . . . 13

III. 3. Flexion . . . . . . . . . . . . . . . . 15

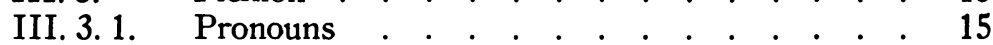

III. 3. 2. Near relationship terms $. . \quad . \quad . \quad . \quad . \quad . \quad . \quad 17$

III. 4. The Verb . . . . . . . . . . . . . . 18

III. 4. 1. The verbal root . . . . . . . . . . . 20

III. 4. 2. The moods . . . . . . . . . . . . . 20

III. 4. 3. The tenses . . . . . . . . . . . . . 22

III. 4. 4. Secondary (aspectual) forms . . . . . . . 23

III. 4. 4. 1. Directive affixes . . . . . . . . . . . 25

III. 4. 4. 2. Objective affixes . . . . . . . . . . . . 26

III. 4. 4. 3. The medial affix . . . . . . . . . . . . . . 27

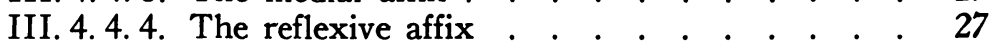

III. 4. 5. Indication of person (with number) for the subject in primary forms . . . . . . . . 27

III. 4.6. Indication of person (with number) for the subject in secondary forms . . . . . . . 29

III. 4.7. Indication of person (with number) for the object in primary forms . . . . . . . . 30

III. 4. 8. Indication of person (with number) for the object in secondary forms . . . . . . . 33

III. 4. 9. Composite verbal forms . . . . . . . . . 35 
III. 4. 10. Indication of the personal object in composite forms .

III. 4. 11. The gerund . . . . . . . . . . . . . 39

IV. PARADIGMATIC LISTS OF VERB FORMS . . . 41

IV. 1. Primary verb . . . . . . . . . . . . 41

IV. 1. 1. Indicative . . . . . . . . . . . . . 41

IV. 1.2. Adhortative . . . . . . . . . . . . . 41

IV. 1.3. Conditional . . . . . . . . . . . . . . . . 41

IV. 1.4. Negative . . . . . . . . . . . . . . . 41

IV. 1.5. Vetative . . . . . . . . . . . . . . 41

IV.2. Primary verb with object affix . . . . . . 42

IV.2.1. Indicative with $2^{\text {nd }}$ p.s. obj. aff. . . . . . . 42

IV.2.2. Indicative with $3^{\text {rd }}$ p.s. obj. aff. . . . . . . 42

IV.2.3. Indicative with $3^{\text {rd }}$ p. du., pl. obj. aff. . . . . 42

IV.2.4. Adhortative with $2^{\text {nd }}$ p.s. obj.aff. . . . . . 43

IV.2. 5. Adhortative with $3^{\text {rd }}$ p.s. obj. aff. . . . . . 43

IV. 2.6. Conditional with $2^{\text {nd }}$ and $3^{\text {rd }}$ p.s. obj. affixes . . 43

IV.2.7. Vetative with $1^{\text {st }}$ and $3^{\text {rd }}$ p.s. and du., pl. as obj. affixes . . . . . . . . . . . . . 43

IV. 3. Secondary verb ... . . . . . . . . . . . . 43

IV. 3. 1. Indicative . . . . . . . . . . . . . 43

IV. 3. 2. Adhortative . . . . . . . . . . . . . 44

IV. 3. 3. Conditional . . . . . . . . . . . . . . 44

IV. 3. 4. Negative . . . . . . . . . . . . . . 44

IV. 3. 5. Vetative . . . . . . . . . . . . . . 44

IV. 4. Secondary verb with object affix . . . . . 44

IV. 4. 1. Indicative Habitualis with $3^{\text {rd }}$ p.s. obj. aff.. . . 44

IV.4.2. Indicative with $1^{\text {st }}$ p.s. obj. aff. . . . . . . 45

IV. 4. 3. Indicative with $2^{\text {nd }}$ p.s. obj. aff. . . . . . . 45

IV. 4. 4. Indicative with $3^{\text {rd }}$ p.s. obj. aff. . . . . . . 45

IV.4. 5. Indicative with $2^{\text {nd }}$ p. du., pl. obj. affixes . . . 46

IV. 4.6. Adhortative with $3^{\text {rd }}$ p.s. obj. aff. . . . . . 46

IV. 4.7. Conditional with $3^{\text {rd }}$ p.s. obj. aff. . . . . . 46

IV. 4. 8. Vetative with $1^{\text {tt }}$ p.s. obj. aff. . . . . . . . 46

IV. 5. Composite verb, Category I . . . . . . . . . 46

IV. 5. 1. Composite verb, Category II . . . . . . . . 48

IV.6. Composite verb with object affix, Category I. 49

IV.6. 1. Composite verb with object affix, Category II 49

V. SYNTAX . . . . . . . . . . . . . 51

V.1. General remarks . . . . . . . . . . . 51

V.2. Word, phrase and sentence .. . . . . . 51 
V.3. Structure of the phrase . . . . . . . . . 52

V.3. 1. Word junction in the phrase . . . . . . . 52

V.4. Predicative constructions . . . . . . . . 53

V. 5. Postpositional phrases . . . . . . . . . 54

V.6. Coordination of words . . . . . . . . . . . . 55

V. 6. 1. Coordination of phrases . . . . . . . . . 56

V.7. Subordination of words . . . . . . . . . 57

V.7.1. Subordination of phrases . . . . . . . . 60

V.8. The parts of speech . . . . . . . . . . 61

V.9. Tense and aspect in the sentence . . . . . . 62

VI. SPECIMEN TEXTS . . . . . . . . . . . . . 68

VI.1. $\quad F a$ nunderwboke da je dowkajnale . . . . . 68

VI.2. $\quad \exists$ balo Jakali le Ajokoj de . . . . . . . . 69

VI. 3. $\quad \exists$ bala Jakali le Hubulew de . . . . . . . . . 69

VI. 4. Translation of VI.1. . . . . . . . . . 70

VI. 5. Translation of VI. 2 . . . . . . . . . . . . . 72

VI. 6. Translation of VI. 3 . . . . . . . . . 73

VII. VOCABULARY . . . . . . . . . . . . . . . 75 


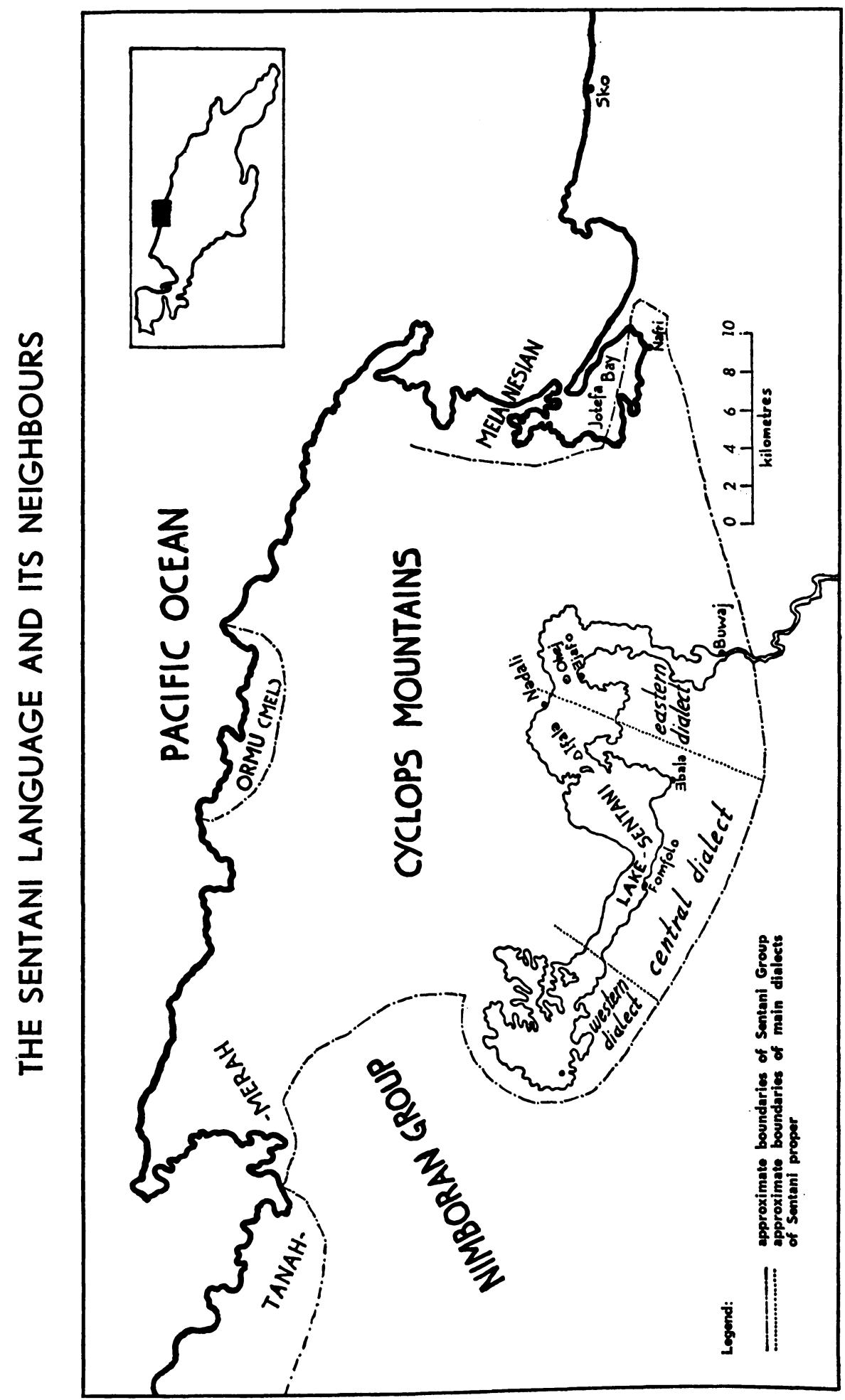




\section{INTRODUCTION.}

\section{1. Litterature.}

The first grammatical description of the Sentani language was published by this writer in Oceania, vols. XXI (1950-'51), pp. 214-228 and 302-309; and XXII (1951-'52), pp. 53-71 and 315-316, under the title of "Notes on Sentani Grammar". It was the result of fieldwork during my stay in West New Guinea in the years 1946-1950. As was stated at the time in the introduction, this fieldwork could only be done to the extent that official civil service duties permitted. But during a further term of service, which finally ended in 1956, I had the opportunity of collecting more data concerning the language. This has led to the present much more complete new grammar.

The following texts have been published by the author before:

(1) A specimen text in the "Notes on Sentani Grammar" forementioned, being a translation of part of the Story of the Prodigal Son, which is now published in full in the present work;

(2) "Een volksverhaal van het Sentanimeer" (in Bingkisan Budi, the collection of papers by colleagues and former pupils of the late Professor $\mathrm{Ph}$. S. van Ronkel, presented to him at the occasion of his $80^{\text {th }}$ birthday in 1950). This appeared before the "Notes" and was, for that reason, provided with an extensive grammatical annotation as well as a translation in Dutch. This text is reprinted in this book in a slightly revised form;

(3) "Drie verhalen in Sentani-taal" (in Bijdragen tot de Taal-, Landen Volkenkunde, 108, 1952). These texts too have been provided with extensive notes as well as a translation, but reference was largely made to the "Notes on Sentani Grammar". A different version of the first of these stories is included in the present work.

\section{2. Area and Relations.}

The Sentani language 1 is spoken by some six thousand people,

1 The name "Sentani" probably originates from the coastal tribes of the Humboldt Bay. The Sentani speaking people have no name for themselves as a tribe. The Sentani Lake is called by them Bu Jakala, "Clear Water".

Verh. dl. 47 
inhabiting the Sentani Lake district in north-eastern West New Guinea. Roughly three principal dialects can be distinguished: an eastern dialect, chiefly including the villages of Buaj (vulgo: Puai), $\exists$ jafo (vulgo: Ajapo) and Ohej (vulgo: Asei); a central dialect including the villages of the central area of the lake from Nodali (vulgo: Netaar) as far west as the western end of the strait of Fomfolo (vulgo: Simporo), and a western dialect including the region to the west of this strait. Smaller differences of dialect exist between the various villages within each area. This grammar is concerned with the eastern dialect, more particularly that of $\exists$ jafo.

The Sentani language is one of a group of closely related Papuan languages, which I have named the Sentani group, and which includes Sentani proper in the Sentani Lake district, the language of Nafri on the Jotefa Bay to the east, and the language of Tanah Merah on the bay of that name to the west. It appears to be more or less distantly related to the Demta language to the west of Tanah Merah, which oocupies only a small area, but seems to constitute a group by itself. Both the Sentani group and Demta seem to belong to a much larger supergroup of distantly related groups of languages, which I have named the "North Papuan phylum", and whose nearest neighbour to Sentani is the Nimboran language group. The exact nature of the relations involved in this phylum, and the position of each group, and notably of Sentani, within it, are, however, still very unclear. ${ }^{2}$

2 See my "Een tweede grote Papoea-taalgroepering in Nederlands Nieuw-Guinea", in Nieuw-Guinea Studiën, I, 1957, 107ff, and the litterature cited there.

See also: J. C. Anceaux, "The Nimboran Language" (VKI 44, 1965) for that language in particular. 


\section{PhONOLOGY.}

\section{1. General Remarks.}

The Sentani language has 7 vocalic and 10 consonantal phonemes. Apart from minor non-distinctive deviations, vowel phonemes have as a rule very fixed phonetic values. But consonantal phonemes are very rich in non-distinctive variants of often strongly deviating phonetic types. These allophones are, generally speaking, "free", although to a certain extent combinatory influences play their part. Only in some cases allophones are positionally "bound".

However, in addition to the "normal" non-distinctive variation referred to above, in which the allophonic limits of the phonemes concerned are not exceeded, there occurs for certain phonemes under certain combinatory conditions an equally non-distinctive variation which does exceed the phonemes' limits of non-distinctiveness. Here there is, therefore, neutralization of the opposition between the phonemes involved in this type of variation. As in the case of the normal allophonic variants, these heterophonemic variants are partly "free", partly positionally "bound".

Thus the $/ \mathrm{h} /$ phoneme has an [s] allophone which is obligatory after nasal, /j/ and /i/, e.g. k\&jsi, "throw away!" (with aspectual affix $-h i$-), but $k \varepsilon j-n \partial-h i$ (with incorporated pronominal object affix). But this allophone [s] also occurs after /w/, e.g. kzwsike, "he threw away (aorist)", in which position, though, it is not obligatory. For here a heterophonemic non-distinctive variant of this $/ \mathrm{h} \sim \mathrm{s} /$ phoneme is also possible, and, as far as my observations go, even more frequent. This variant is [f], itself a labiodental variant of the fricative phoneme /f/ which as such has both labiodental and bilabial allophones. Hence there is, after $/ w /$, freedom of choice between allophonic [s] and

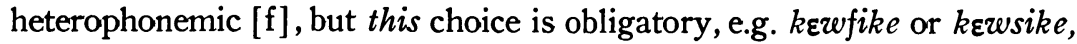
and not *kשwike.

In certain speech-forms, notably in the central dialect, this [s] and [f] may even occur as non-distinctive variants of the /d/ phoneme, after $/ \mathrm{j} /$ and $/ \mathrm{w} /$ respectively. This may be due to the facts described in note (5) hereafter. We will normally disregard these dialectal peculiarities, except in those texts in which they happen to occur. We 
will, of course, equally disregard in our spelling normal non-distinctive combinatory changes, such as $[\tilde{n}]$ for $/ n /$ and $\left[d^{\prime}\right]$ or $\left[t^{\prime}\right]$ for $/ d /$ after $/ \mathrm{j} /$ and $/ \mathrm{i} /$; etc. But we cannot, in our phonemic notation, neglect the heterophonemic variation, which occurs in our eastern dialect. Nor even can we, in my opinion, ignore in our notation the allophone [s] of the $/ \mathrm{h} /$ phoneme, because of its obligatory nature and its deviating phonetic type. Similar considerations apply to the partial neutralization of $/ \mathrm{d} /$ and $/ 1 /$, and the mutual assimilations of the nasals $/ \mathrm{m} /$ and $/ \mathrm{n} /$, or their interchange in assimilation to other consonants; and certain other phenomena.

In the following pages these phonetic phenomena, both of an allophonic and a heterophonemic nature, will be treated when dealing with the phonemes concerned. Any further morphophonemic implications of a more specific nature will be indicated when the morphological constructions concerned are dealt with. They are not so complicated as to justify a separate section on morphophonemics. Since similar phonetic phenomena occur in certain syntactic constructions, this syntactophonemic aspect will be discussed in its proper place also (see V. 3. 1).

\section{2. Vowels.}

The Sentani vowel system is as follows:

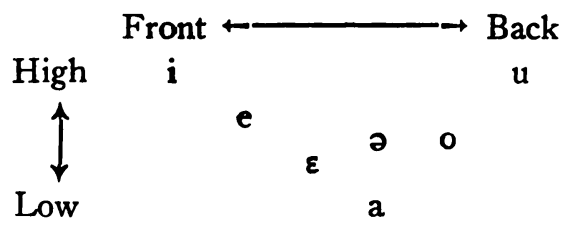

Allophonic variants of these vowel phonemes, if compared with the consonants, are generally slight. They are mostly limited to minor differences in length and/or tenseness (narrowness) of articulation, those in stressed open syllables being pronounced longer and more tensely than those in closed or unstressed open syllables. In the case of $/ 0 /$, which is a mid back vowel, this goes parallel with a variation between higher and lower positions, and for $/ \partial /$, a mid indifferent vowel, between [ö] and [ə] types respectively. 3

3 There are indications that, from a historico-structural point of view, the / / / phoneme has originally filled, in a different phonetic form, the empty place now existing in the mid-back vowel sequence if compared with the mid-front 
/a/, though shown as a low indifferent vowel, is usually pronounced frontally rather than backwardly.

In open accentuated syllables of words of more than one syllable /i/ is often lengthened to such an extent that it even tends to diphthongize to [ij], which in an extreme type of articulation sometimes even becomes [ig] in conformity with the fact that $/ j /$ after $/ j /$ or $/ i$ / is frequently pronounced in its non-distinctive variant $[\check{g}]$, e.g. im "house" [ime, ijme, iğme].

Nasalized vowels sometimes occur as non-distinctive variants of vowel followed by syllable final nasal, notably before $/ \mathrm{k} /$, more rarely before [s]. Sometimes the nasalization is dropped or almost dropped and the vowel at the same time slightly lengthened. This lengthening is no more phonemic than the one mentioned before, since the relevant feature in question is not long vowel as opposed to short vowel, but vowel + nasal (with variants) as opposed to simple non-nasalized vowel. E.g., awbaNkə [awbankə, awbãkə, awba:kə], "cassowary"; HaNsə [hansə, haṅsə, hãsə, ha:sə], proper name (from Dutch Hans); etc.

The following examples show the vowels in their phonological oppositions to each other:

$a$, "voice" : $o$, "wood" : $u$, "body" : $i$, "fire";

$f a$, "child" : $f_{\varepsilon}$, "leaf" : $f i$, "sago" : fa, "fear";

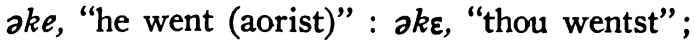

$m e$, "we" : me, "our(s)" : ma, "hand" : mi, "louse" : mu, "penis" : mo, "just, only";

$j u$, "sugar cane" : $j o$, "village" : $j \varepsilon$, emphatic particle : ja, "firewood" : $j a$, "day, rain"; etc.

\section{3. Consonants.}

The Sentani consonants are:

$\begin{array}{lccccc} & \text { plosives } & \text { fricatives } & \text { nasals } & \text { lateral } & \text { semivowels } \\ \text { labials } & \mathrm{b} & \mathrm{f} & \mathrm{m} & & \mathrm{w} \\ \begin{array}{l}\text { gingivals } \\ \text { prepalatal }\end{array} & \mathrm{d} & & \mathrm{n} & 1 & \\ \text { velar } & \mathrm{k} & & & & \mathrm{j}\end{array}$

laryngeal

h

vowel series. Compare, for instance, the variation of Sent. dow - $=$ dowə-, "take"; of west dial. kəsi = east dial. kiho, "sand" (with metathesis); of Sent. olo- = Nafri (see I. 2) oro-, "speak"; and cf. Sent. domə = Demta (see I.2) dum, "tail"; Sent. hijako = Demta jaku, "bird of paradise"; etc. 
The plosives /b/ and /d/ are unvoiced lenes, respectively bilabial and gingival, but free non-distinctive variants include unvoiced and voiced types. 4 An extreme unvoiced combinatory variant of $/ d /$ is palatalized [ $\mathrm{t}^{\prime}$ ] which occurs in contact with $/ \mathrm{i} /, / \mathrm{j} /, / \mathrm{u} /$ and $/ \mathrm{w} /$. $V i a$ a voiced allophone of $/ \mathrm{d} /$ there is sometimes neutralization of the opposition between this phoneme and $/ 1 /$ in intervocalic position, e.g., ambulo, "dead (man's) body" (for *ambu-do, from do, "man"; cf. ambomije, "dead (woman's) body"); kilo, "new-born (male) child"

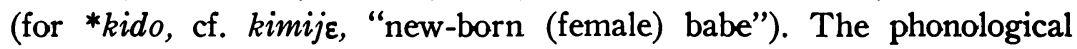
opposition between $/ \mathrm{d} /$ and $/ 1 /$ is otherwise shown by such pairs as odo : olo and ada- : ala-, mentioned at the end of this section.

$/ \mathrm{k} /$ is a voiceless velar plosive whose allophones include uvular [q] on the one, and palatal $[\mathrm{k}]$ on the other hand, as well as velar fricative $[\mathrm{x}]$. These allophones are generally speaking free; naturally contact will have its influence, but it is not decisive, and both the uvular and velar types and the palatal will be heard in contact with front as well as back vowels.

The fricative /f/ has labiodental and bilabial allophones. Through the former the phonological opposition with $/ \mathrm{h} \sim \mathrm{s} /$ is neutralized under certain combinatory conditions, $[\mathrm{f}, \mathrm{h}, \mathrm{s}]$ then varying heterophonemically according to the nature of the contact phonemes (see II. 1. supra).

The laryngeal fricative $/ \mathrm{h} /$ has a bound allophone [s] which is restricted to, and - except after / $\mathrm{w} /$ - obligatory in, the position following $/ \mathrm{i}$ / or one of the only admissible syllable- and word-closing consonants, viz. the semivowels and $\mathrm{N}$ (the latter then appearing as $n$ ). Although it is non-distinctive, we shall write this $s$ where it belongs because of its obligatory and phonetically deviating nature. E.g., isam, "anger"; honsom reduplicated root-form (gerund) of hon(a)-, "burn"; $k \varepsilon j s i$, "throw away!" (2 p.s. imperat.); kqnsi, "id." (2 p.p.); but $k \varepsilon j n a h i$ [kejñahi] (with pron. obj. aff. 3 p.s.); balaw-sabakaj (for *balaw-habakaj), "betelnut (and) tobacco", i.e. "betel-quid"; etc. Under certain conditions, already referred to above, this [s] may, after semivowel /w/, interchange with labiodental [f], thereby neutralizing the

4 In the western dialect phonemic distinctions seem to be between $/ b /$ and $/ d /$ on the one hand and slightly aspirated $/ \mathrm{p} /$ and $/ \mathrm{t} /$ on the other. Comparison shows that these $/ \mathrm{b} /$ and $/ \mathrm{d} /$ correspond to $/ \mathrm{b} /$ and $/ \mathrm{d} /$ in our eastern dialect, while $/ \mathrm{p} /$ corresponds to $/ \mathrm{f} /$ and $/ \mathrm{t} /$ to $/ \mathrm{h} /$. 


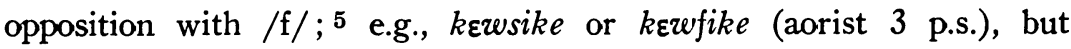
never *kewhike.

The nasals are neutralized in final position, which neutralization can be symbolized by $\mathrm{N}$, realized as [m, n] or [i] according to the following consonant in the word or in phrase sandhi. But in pausal and non-assimilating positions, e.g., before vowel of a following word or in slow speech, $m$ is "preferred" as word-final, dialectally, notably

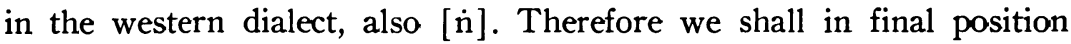
write $m$ instead of $\mathrm{N}$. On the other hand we shall not, for obvious reasons, write $[\dot{\mathrm{n}}]$ nor $[\tilde{\mathrm{n}}]$, which allophones occur before $/ \mathrm{k} /$ and before and after $/ \mathrm{i} /$ and $/ \mathrm{j} /$, respectively. E.g., $\partial m$ (western dialect $\partial \dot{n})$, "banana" : $\boldsymbol{a} m f_{\varepsilon}$, "banana leaf", but $\partial n$ no, "banana treetrunk"; ahamam, "food", ahamam anake, "he ate food", but ahaman da, "for food"; honaj, "burn!" (2 p.s. imperat.), but honsom, "burning"; mandilim, "cold" : mandilin na or mandilim ma, "in cold, for cold"; etc.

The voiced lateral in gingival position / $/$ is apical, but the tongue tip is allowed little more than a minute and momentary touch against the upper gums. This may explain why there is the neutralization with /d/ already referred to. It probably also explains why non-natives often hear and reproduce it as $r$. In the western dialect it actually is a tongue flip rather than a lateral. E.g., (odo) halam (w.dial. odo taran), "knee"; (odo) ka'la-ka'la (w.dial. odo kəkə'ra), "toe"; malem (w.dial. mare $\dot{n}$ ), "meat, flesh"; etc. This phoneme only occurs intervocally and never as word-initial nor after consonant. In the latter two positions it is represented by /d/ as bound and obligatory heterophonemic variant. An apparent exception to this rule is word-initial $l$ in the postposition $l e \sim d e$, "with, and". But this being enclitic to the preceding word, it is not really an exception, for it occurs only after words ending in a vowel, while $d e$ occurs after words ending in a consonant; e.g., $\exists$ baw de Nakahabo le, "(and) the Tortoise and the Lobster"; Jakali le Ajokoj de, "(and) J. and A."; etc.

$/ \mathrm{w} /$ is a strongly rounded bilabial semivowel. There are reasons to believe that it is a comparatively recent phonemicization of a nonsyllabic allophone of an original sonant $/ \mathfrak{u} /$. Its functional yield as

5 In the western dialect $/ \mathrm{h} /$ does not exist. Our $/ \mathrm{h} /$ corresponds to $/ \mathrm{s} /$ in that dialect in so far as it does not represent $/ t$ / in the latter (cf. the preceding note). In the Nafri and Tanah Merah languages (see I.2) /s/ represents our eastern $/ \mathrm{h} /$ both where it corresponds to west $/ \mathrm{s} /$ and to west $/ \mathrm{t} /$. These facts and those mentioned in the foregoing note, together with dialectal intermixing, may probably account for the neutralization phenomena described in II. 1 , and here. 
phoneme, distinct from $/ \mathrm{u} /$, is small. We have little more than the following evidence: wi, "river" : $u j$, "arrow"; central dial. 'ua, 'uwa, "body" (east. dial. u) : wa, "skin"; huw-=huwa-, verbal root of "feel" (cf. a-huw-boj, "not feel") : hu, "sun"; duw-=duwa-, root of "fall" (cf. duwke, "he fell"): $d u$, "breadfruit tree"; and this same word duwke in similar surroundings as duka, "stone"; etc. But wi could be an Austronesian loanword (cf. AUN *wayəy), which in a number of Melanesian languages occurs as wai or vai. And ua, uwa belongs in another dialect. The other examples are not, strictly speaking, minimal pairs. I have never come across a pair such as, e.g., *wu : *uw. And initial syllable wa- in polysyllables frequently contracts to $u$-, $u w-$. Yet, originally an Austronesian loanword or not, wi is a good Sentani word, and clearly contrasts with $u j$. And the additional evidence, however weak, also points to $/ \mathrm{w} /$ as a separate phoneme now.

Similar considerations, mutatis mutandis, apply for $/ \mathrm{j} /$ as distinct from $/ \mathrm{i} /$. The same minimal pair $u j:$ wi again is our main evidence. No pair $*_{j i}: *_{i j}$ has been found. But we may contrast $j i$ in $k a^{\prime} j i$, "big canoe for women and children", with $i j$ in $i j k e=i k e$ (for $j e k e$ ), "he climbed", and similar $i j$ variants of $i$ in open stressed syllables (cf. II. 2). This phoneme has a non-distinctive variant $[\check{g}]$ occurring after $/ \mathrm{j} /$, sometimes also after /w/, and often after /i/ in its lengthened and diphthongized variant [ij], which then often sounds like [iğ] ; e.g., awajjajde [awəjğajde], "they are rowing all the time" (with -ja- of

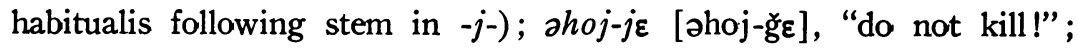

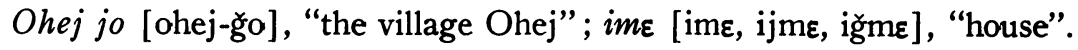

The following are some further examples showing the consonants in their mutual phonemic oppositions :

$b a$, "only, just" : $f a$, "child" : ma, "you" (du., pl.) : $w a$, "thou" : $d a$, "I" : na, "he, she, they" : $k a$, "fish" : ja, "rain, day" : ha, "blood";

$b u$, "water" : $d u$, "breadfruit tree" : $h u$, "sun" : $j u$, "sugar cane"; obo, "pig" : odo, "foot" : olo, "empty" : oko, "moon" : ojo, "descend";

adaj, "look!, see!" : alaj, "speak" : ajaj, "going";

maw, "he must come" : maj, "come thou!" : mam, "come you! (du., pl.)".

\section{4. Phonemic structure of the word.}

It is convenient to analyze the phonemic structure of the Sentani word on the basis of its syllables. A syllable consists of either one 
single vowel, or such a vowel preceded and/or followed by one single consonant, nasal and semivowel being the only consonants admitted as syllable finals.

A word contains one or more such syllables, but it cannot consist of two or more vowels alone. The structure of the Sentani word is, therefore: v, cv, vc, cvc; or for polysyllables: vcv, cvcv, vcvc, cvcvc, vccv, cvccv, cvccvc, vcvecv, etc., accompanied by the suprasegmental element of stress, to be discussed hereafter, and with the restrictions as to final consonants stated above for syllables, but with the additional restriction that $/ 1 /$ does not occur as word initial nor after consonant (cf. II. 3). E.g., a, "voice"; fa, "child"; do, "man"; am, "banana"; aj, "go!"; aw, "he must go"; mam, "you must come"; aha, "dung"; male, "he comes"; adaj, "look!, see!"; wanam, "let us two tell him"; ande, "we go"; majde, "they come"; mannam (< mam-nam), "come (and) stick"; uwowna (for wawowna), "they two have been telling him"; etc.

\section{4. 1. Stress.}

Stress in words of more than one syllable lies as a rule on the syllabic preceding the last consonant of the word, e.g., 'joku, "dog"; 'mije, "woman"; 'kambi, "neck"; ho'kolo, "young"; mo'kodu, "back"; a'dake, "he saw" (aorist); 'hojbo, "kill!"; u'kawna, "he told him"; ma'kajde, "they came"; but: fa'lam, "head"; $e^{\prime} m \varepsilon m$, "sister-in-law (husband's sister)"; $a n^{\prime} k \varepsilon j$, "ear"; $a^{\prime} w a w, ~ " m o t h e r ' s ~ b r o t h e r " ; ~ h a b a ' k a j$, "tobacco"; holo'boj, "carrying net"; a'laj, "speak!"; bo'doj, "hear!"; adi'laj, "collect!"; a'dam, "see you (du., pl.)"; hodo'bom, "let me kill".

In words of 3 and 4 syllables, ending in a vowel, which have the antepenult closed by a consonant, the stress tends to shift to this syllable, if the penult is an open syllable in $\partial$, e.g., 'warenale, "thou wilt say to him"; 'kعjnəhi, "throw it away"; $u^{\prime}$ kajnale, "they (pl.) told him"; but: how'boke, "he killed (something)"; hoj'nobo, "kill something) for him"; handa'boke, "we (pl.) killed (something)"; honəm'bonde, "he will kill (something) for him"; etc. In longer words the main stress falls on the regular syllabic according to the basic rule stated above, a secondary stress affecting the $3^{\text {rd }}$ syllable forward from the main stress, or the $2^{\text {nd }}$ syllable forward if this is closed by a consonant, e.g., ha,bawdo'koke, "he hit me" (aor.); ha,bawnoko'kale, "I struck him" (aor.); ha,bawkoka'wale, "I have struck thee"; , adəka'wale, "I saw thee"; adi,ladami'him, "let me collect them"; a,dilami'hibe, "you two will collect them"; a,najna'wande, "they (pl.) will go tell 
him"; a,najnakहn'sinde, "they (pl.) will throw it away"; etc.

Deviations and variations from the above rules are, however, not unfrequent. Verbal roots of more than one syllable ending in -a preceded by one of the consonants admissible as finals, tend to treat this consonant as root final and drop the $-\partial$, when an affix, beginning with a consonant, follows. The stress then remains on the syllable, which would carry it in the root, e.g. ano-, "eat": 'an(o)ke, "he ate"; 'an(a)ma > amma, "let us eat"; dowa-, "take" : 'dow(a)ke, "he took"; duwa-, "fall" : 'duw(a)ke, "he fell"; etc. But the stress shifts from this root syllable to the affix (or one of the affixes if there are more), in regular conformity with the basic rules stated above, if it ends in a consonant itself, e.g., $a^{\prime} n a j$, "eat!"; hon'karwna (for honəkarwna), "he burnt him", from hona-; honsom, "burning" (gerund; for hon(a)$\operatorname{hon}(a))$; etc.

Sometimes differences in stress exist between different dialects, e.g., $k a^{\prime} j i$, "big (women's) canoe", but 'kaji in the central dialect; 'hodo, "throat", but sa'to in Nafri and sa'so in Tanah Merah; etc.

In some adjectives and adverbs stress is found on the final syllable, even if this ends in a vowel, but it is doubtful whether this can be said to be a characteristic feature for these word classes (cf. V. 8), e.g., $h \partial^{\prime} l \varepsilon-h \partial^{\prime} l \varepsilon$, "thin"; $f e^{\prime} n \varepsilon$, "slippery"; $\partial^{\prime} h \partial$, "heavy" (in the central dialect in opposition to 'aha, "dung" = kEndo in our dialect); wa'la-wa'la, "quick(ly); nahu'we, "in the evening(s)" (cf. 'huwe, "evening"); etc.

Sometimes, however, stress has distinctive function, e.g., 'kala, "shellfish" (regular), but $k a^{\prime} l a$, "shout, yell" (irregular); $a^{\prime} l a j$, "speak thou!" (regular), but 'alaj, "not speak" (irregular); etc.

But often irregularities in stress have no demonstrable distinctive value whatever, e.g., i'fa, "small canoe for men"; $u^{\prime} m a$, "hair of the head"; fa'la, "bow-and-arrow"; etc. ${ }^{6}$ We shall indicate such irregularities of stress by a high dash preceding the stressed syllable (a low dash means a secondary stress).

- Possibly historical causes, such as loss of original final consonants, have been at work here, at least in some of the examples; compare, e.g., $i^{\prime} f a$, in west dial. $i^{\prime} p a$, with Demta apar, same meaning. 


\section{MORPHOLOGY.}

\section{1. Morphological structure of the word.}

The Sentani word is either a simple or a complex form. But a form is not necessarily a word, because some forms occur in bound position only. A simple word contains one root. A complex word consists of one or more roots to which a morphological process has been applied. The morphological processes are:

1. prefixation to verbal roots of the negative prefix 2 - (unique case);

2. affixation, by which we understand the adding to the verbal structure of all flexional elements which follow the root, irrespective of their own mutual order;

3. phonetic root change or apophony ;

4. suppletion, including (unique case) zero feature;

5. morphological repetition (dialectally also represented by reduplication), as distinct from syntactical repetition;

6. composition ;

7. combination of two or more of these processes.

Complex words can be distinguished in derived and inflected forms, according to the criteria set forth for this distinction by $\mathrm{L}$. Bloomfield (Language, London 1950, pp. 223-4), although, as we shall see, these sometimes fail us.

Derivation is limited to the processes mentioned under nos. 5 and 6 . Flexional processes include all of those mentioned.

\section{2. Derivation, (1) repetition.}

Words derived by repetition (derivational repetition as distinct from flexional repetition) are usually adjectives and adverbs, which seem to imply an intensive or excessive quality. They have the characteristics of a single unit, both in stress and in meaning, which latter is an independent, if derived, one of their own; e.g., kalan-kalam, "dry"; kani-kani, kankam, "torn to shreds"; hale-hale, "thin"; dun-dum, "fat"; waw-waw, "deep"; (west. dial.) nimə-nimə, "red" (cf. nimə, "ripe") ; etc.

Sometimes they seem to be derived from nouns, to which the specific 
quality is attributed in particular, e.g., $d u k a-d u k a$, "thick, massive" (cf. duka, "stone"); foma-foma, "light (not heavy)" (cf. foma, "coconut rat", a very light animal); bobo, "hard" (cf. bo, "bone"); etc.

Rarer is repetition in nouns; no specific meaning of the simple root can be recognized; e.g., (odo) kala-ka'la, "toe" (odo = "foot"); ( $\left.k \partial^{\prime} n a\right)$ kon-kom, "spittle, phlegm, gob" (cf. ka'na, "heart, pith"); etc.

A variant of this type of derivation is repetition with vowel or even syllable variation (apophony) in the $2^{\text {nd }}$ constituent, e.g. dawbahidawbahi, "one side (and) the other, here and there, hither and thither" (cf. ahi, "other"); kqw-kaw, "broad, wide"; ama-foma, "entire(ly), total(ly)"; hikoj-sakoj, "exhausted, tired"; adaj-madaj, "invisible, unseen" (cf. ada-, "see", and negative prefix a- ?); etc.

\section{2. 1. Derivation, (2) composition.}

Words derived by composition (derivational composition as distinct from flexional composition) consist of usually two constituent words which together have the characteristics of a single unit. They are nouns denoting either a generality or collectivity of the combined sememes of the constituents, or a determination of the $2^{\text {nd }}$ constituent by the first, or, if the determinant is an adjective, inversely, or a relation of origin in which the second constituent stands to the first. Sometimes the compound consists of a short phrase, in which case it may contain more than two constituents. Examples: do-mije, "human being(s)", from do, "man", and mije, "woman"; obo-joku, "animal", from $o b o$, "pig"; and joku, "dog"; kaji-i'fa, "canoe (in general)", from $k a^{\prime} j i$, "big women's canoe", and $i^{\prime} f a$, "small men's canoe"; isam-fa'la, "war", from isam, "anger", and fa'la, "bow-and-arrow"; jobo, "tame pig", from jo, "village", and obo, "pig"; u-makaj, "character" (from $u$, "body, person", and məkaj, "manner, way"); a-few, "language", from $a$, "voice, sound", and few, "tongue"; ambu-lo, "dead (man's) body" (cf. do, "man"); ambo-mije, "id. (woman's)"; ki-lo, "infant

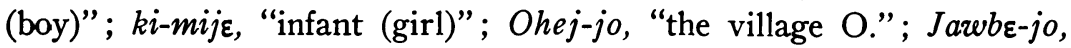
"J. village"; $u$-foj, "slave", from $u$, "body", and foj, "good" (as distinct from $u f o j$, "good, i.e. healthy, body"); but in inverse order: hoko'lo-fa, "the younger or youngest child (of a family)" (as distinct from fa $h o^{\prime} k o l o$, "the or a young child"); bə'na-fa, "the elder or eldest child (of a family)" (as distinct from fa'bana, "the older child"); a'hamam, "food", from $\partial h a$, "thing", and $a m$-am, i.e. an(ə)-an(o), "eating" (with shift of the stress to the contracted vowel); and with short phrases: a'han(a)jala, "rations", from aha, "thing", and anajjale, "he uses to 


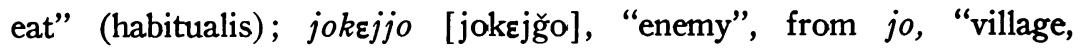
people", $k \varepsilon j$, "throwing", and again $j o$; etc.

A sort of abstract nouns is sometimes indicated by preposing the $3^{\text {rd }}$ person pronoun $n a, n a, n$ - in composition, and this may be, originally and essentially, the same formation as that of certain "adverbial" expressions with this pronoun (cf. III. 3.1 and V.8); e.g. na-hala, "justice" (cf. hala, "right, true, real"); nə-bam, "badness, sin" (cf. bam, "not, no good"); n-ama, n-ama-foma, "entirety, totality", and hence: na n-ama (-foma) na, "in its entirety, entirely" (cf. ama(-foma), "whole, all, entire").

Derived by composition is also the numeral " 5 ", those from " 1 " to "4" being simple root-forms, while those from " 6 " to "9" are partly composed and partly syntactical constructions, and those for " 10 " and higher are only syntactical; e.g., mahambaj, "5" (<ma $f_{\varepsilon}$ ambaj, "handpalm one"); but mahina ambaj, " 6 " (<ma ahi na ambaj, "on the other hand one"); mahina be, "7" (< ma ahi na be, "on the other hand 2"); mahina nama, " 8 "; mahina kali, "9". For the syntactical constructions, see V. 6 and V. 8.

\section{2. 2. Borderline cases.}

With regard both to repetition and to composition there are cases which may cause doubt as to whether they are derivational or rather flexional, on the one hand, and whether they are at all morphological or rather syntactical, on the other. To a large degree this may be due to the very strong tendency of the language to phrase sandhi, whence both morphological and syntactical constructions are close units, phonetically, while both stress and meaning are not always decisive. Hence the basic criteria for morphological composition and repetition, as distinct from syntactical, to be regarded as forming single words, sometimes fail us. Thus jobo, "tame pig", is clearly composed, and therefore a morphological construction, both because of its contracted form, its stress and its specific meaning (' $j o$ 'obo would mean "the village's pig"). But its opposite is $a k \partial^{\prime} l a$ 'obo, "wild pig" (litt. "jungle pig"), and neither stress nor form, and hardly even its meaning, would mark it as a composite word. Here we have the syntactical construction of the subordinative type (1) of V.7. Similarly there is no doubt about words like ambu-lo, "dead (man's) body", and ki-lo, "infant boy" (from do, "man, male"), being composite. On the other hand a construction like $d o m i j \varepsilon$, which we have already mentioned as a composite word in III. 2.1., has little else to mark it as morphological or syntactical 
than its meaning, and, as subject in the sentence, its predicate. Thus do-mije can mean "human being" ("man-woman") and is then constructed with a verbal predicate in the singular, e.g., do-mije hadake, "human being (who) died, dead person". This is clearly a composite word. The construction can also mean "people" and then takes a verb in the plural, e.g. Ohej do-mije akajde, "the people of Ohej went off". This we can still regard as a composite word. But $d o$ mije may also very simply mean "man (and) woman" or "men (and) women", naturally with the verb in the plural or dual as the case may be. The last mentioned construction is syntactical of the serial coordinative type without coordinator (see V.6). But it should be remarked that these distinctions are not always so clearly marked as our analysis would lead us to suppose. Thus in a sentence like jej bi foma do do mije do jejbojme da do bodojdobojme, "hey there, coconut rat, if you could become a human being (litt.: to man (or) to woman), you would understand me", the two constituents of what should be the one composite word $d o-m i j \varepsilon$ are each separately followed by the postposition $d \partial$.

Similar cases are such constructions, already mentioned in III. 2. 1, as obo-joku, "animal" (litt. "pig-dog") and kaji-i'fa, "canoe (in general)", which can also have their litteral meaning of "pig(s) (and) dog(s)"; "women's (and) men's canoe(s)". Although in the second example stress seems to be more distinctive because $i^{\prime} f a$ (like $k a^{\prime} j i$ ) carries an irregular final stress, the two vowels, on the other hand, never seem to be contracted as in jobo forementioned.

Similar problems sometimes arise where repetition is concerned. For nominal forms it is not too difficult to decide. While examples as duka-duka, "thick, massive", and foma-foma, "light" (if they are at all derived from $d u k a$, "stone", and foma, "coconut rat" and are not merely homonymous with these nouns), have a distinct meaning of their own, an expression like ja ja may be translated by "daily", but really means no more than "day (and) day, day (after) day", and need not be regarded as anything else than a syntactical construction.

For repetition of verbal forms, however, the decision may sometimes seem more difficult. Here, moreover, the choice may be between derivational and flexional repetition. Thus the repetition of verbal forms, dealt with in V. 6 , is to be regarded as a syntactical coordinative construction because the constituents are each fully, independently and identically inflected forms, retaining their proper stress, and the meaning of the combination remaining unchanged, although repetitive; e.g., awkajde awkajde, "they rowed (and) rowed"; honkawna honk- 
arena, "he burnt him (and) burnt him". Similarly it is clear that the gerund (III. 4. 11) is a morphological, and even flexional, form, because it constitutes one word, structurally, and has a distinct function of its own; also it has properties which are characteristic of verb flexion, such as the capacity of taking an aspectual affix (in which case the repetition is omitted!), e.g. honsom (for hon(a)-hon(a)), "burning"; $\operatorname{dow}(a)-\operatorname{dow}(a)$, "taking”; $b \varepsilon j-b \varepsilon j$, "seeking"; etc.

But combinations of this gerund with other forms of the same root may raise doubts. We have in III. 2 mentioned combinations like hikoj-sakoj, "exhausted", and $a d \partial j$-madaj, "invisible, unseen", as a variant type of derivational repetition, because their connection with the verbs hiko-, "swim", and ado-, "see", if any, is distant, their meaning has differentiated, and the vowel, respectively syllable, variation is typical. But a strong possibility remains that they are, if only in origin, derived from gerund forms. On the other hand we have in III. 4. 11 considered forms like ojboj-owboke, "collapsing-it-collapsed", and dejko-dewnokoke, "penetrating-it-penetrated-into-it", i.e. "it penetrated deeply into it", as flexional composition and not even as flexional repetition, because, although the two constituents contain the same root, with the same meaning, they are too different formally and functionally for the combination to be regarded even as an apophonic variant of the derivational repetition of III. 2. supra. Also, unlike syntactical repetition of verbal forms, the two constituents are not identical and not independent, and they do not have each the same functional position in the compound.

\section{3. Flexion.}

Flexion is limited to the verb, the personal pronouns, and a few near relationship terms. Of these the flexion of the verb is by very far the most important. The term "flexion" for pronouns and relationship words is a somewhat big name, although justified, for a very limited number of special forms.

The flexion of the verb includes the processes mentioned in III. 1 under nos. 1, 2, 5-7, while pronouns and relationship terms follow processes nos. 3, 4 and 6 . The latter will be treated first.

\section{3. 1. Pronouns.}

Four main series of forms of the personal pronoun can be distinguished, which we can regard as inflected by means of phonetic root change or apophony, since, although historically they may represent 
little more than different degrees of emphasis, they have largely specific grammatical functions. Some types have abbreviated or contracted subforms. The following table shows the four series.

\begin{tabular}{|c|c|c|c|c|}
\hline Person & I & II & III & IV \\
\hline $1^{\text {tt }} \mathrm{sg}$ & dəjह & da & $\mathrm{d} \varepsilon \mathrm{j}$ & də \\
\hline $2^{\text {nd }} \mathrm{sg}$. & wəje & wa & wej & wə \\
\hline $3^{\text {rd }} \mathrm{sg}$ & nəjह & na & $\mathrm{n} \varepsilon \mathrm{j}$ & no \\
\hline $1^{\text {st }}$ du., pl. ex. & mej $\varepsilon$ & me & $\mathrm{m \varepsilon j}$ & - \\
\hline $1^{\text {tt }}$ du., pl. in. ${ }^{7}$ & ejह & (e) & $\varepsilon \mathrm{j}$ & - \\
\hline $2^{\text {nd }}$ du., pl. & məjह & $\mathrm{ma}$ & maj & mə \\
\hline $3^{\text {rd }}$ du., pl. & nəjह & na & $n \varepsilon j$ & nə \\
\hline
\end{tabular}

The no. I series, which is probably composed with the emphatic particle $j \varepsilon$, contains the stressed absolute forms of the personal pronoun. The no. II forms are at the same time the indifferent absolute forms of the personal pronoun used as subject, the personal forms used with postpositions, and the possessive forms. In quick speech they may be abbreviated to $d$-, $w$-, etc. before vowel, except for the $1^{\text {st }}$ p. du., pl. incl. and excl. No. III is a strongly stressed possessive, also used as absolute (substantive) possesive (Eng. "mine, yours"), and hence as a kind of reflexive (Eng. "myself, yourself"). It is sometimes abbreviated to $d \varepsilon$, wz, etc. The $3^{\text {rd }} \mathrm{p}$. is also used sometimes as a demonstrative; and this may be the case also for $n a$ of the II series, if at least $n a$, no in the abstract nouns of III. 2.1 and in certain adverbial expressions as na-huwe, "in the evening(s)" (cf. huw, "evening"); na-denijaj, "in the night(s)" (cf. denijaj, "night"), and others (cf. V. 8), must be regarded as demonstrative and not as possessive. The no. IV series lastly represents a toneless proclitic possessive, which is often, though not necessarily, abbreviated to $d$-, w- etc. before vowel, but which is not a prefix, and is not essentially different from no. II as possessive. Often the two types may be used for each other, e.g., da shamam or da ahamam, "my food"; na falam or na falam, "his

7 I have included this "inclusive" form of the $1^{\text {st }}$ p. du., pl., although it is not in general use and is probably a dialectal form adapted to this specialized end under Austronesian influence. For in the closely related Tanah Merah language the unique form for the $1^{\text {st }}$ p.du., pl., both inclusive and exclusive, is $e^{\prime} e$, while it is $m i$, me in Nafri. Also in the inflected forms of the verb there is not a single trace of separate inclusive and exclusive $1^{\text {st }} \mathrm{p}$. du., pl. forms. The series II type of this pronoun $(e)$ is put between brackets because I have never met it in actual usage, while my informants were divided in their opinions on the point. 
head"; but often also speech usage assigns the one or the other form to definite words, e.g., wa ma, "thy hand"; na dama, "his tail"; $n a$ ime, "his house"; na jo, "his village"; na kalu, "his (brother's) son"; $d a$ u, "my body"; etc., but na fa, "his child" (though na hokolo-fa, "his younger child"); na a'hanajala, "his rations"; na waku, "his drum"; na jam, "its (the house's) roof"; etc. Neither euphony nor classification of nouns plays a demonstrable part in this, although, naturally, the latter may have existed in an earlier phase of the language and may have had its influence at the time.

\section{3. 2. Near relationship terms.}

The relationship terms "father" and "mother", when taking the possessive of the $1^{\text {st }}$ and $3^{\text {rd }}$ person before them, supply a special possessive-determined form, which can be regarded as "flexional", and which is ako for "father" and naka for "mother". Normally these words are only used in the sense of "venerable old man, old woman", the normal terms for "genitor" and "genitrix" being adaj, ajd $j$ and ana respectively. The latter are used as vocatives by the child speaking to its parents, and with a zero allomorph of the $2^{\text {nd }}$ person possessive, i.e., without special indication of the possessive in this person unless it is stressed, as the possessive-determined form for the $2^{\text {nd }}$ person by others addressing the parents' child or children. The suppletive allomorph ako, "father", takes, in principle, the possessives of the III ${ }^{\text {rd }}$ series before it, but the $1^{\text {st }}$ p. du., pl. $m \varepsilon(j)$ is also used as suppletive allomorph for the $1^{\text {st }}$ p. sg., and the construction, unless when the possessive is stressed, is contracted so as to become one word, thus: $m \varepsilon-k o$, "my, our father"; $n \varepsilon-k o$, "his, their father". It can, therefore, be best described as a composite form as distinct from the simple preposing of the possessives of series II, III and IV, which is a syntactical process (cf. V.7). It cannot be regarded as a prefixed form, since $m \varepsilon$ - and $n \varepsilon$ - are not bound forms, but also occur independently. There is then a clear analogy with the composition of nouns described in III. 2.1 and III. 2. 2 as distinct from the syntactical subordinative combination of nouns.

The suppletive form naka, "mother", also takes the $1^{\text {tt }}$ p. du., pl. for the $1^{\text {tt }}$ p. sg., but, having an initial consonant, the contraction affects the possessive differently: ma-naka, "my, our mother"; na-naka, "his, their, mother". Here we have a borderline case between composed and prefixed form; but for the sake of uniformity I prefer to treat 
this form as the preceding, with the additional note that the vowel has been strongly affected and weakened to $\partial$.

The relationship terms awaw, "mother's brother", and aka, "elder brother, or sister", follow the same rules, both as to the type of possessive and the contraction, as ako, "father", but they are not suppletive possessive-determined forms themselves, e.g., ne-waw, "his uncle".

In the $2^{\text {nd }} \mathrm{p}$. there is, as we have said, not even suppletion for the words "father" and "mother", and the normal "vocative" forms of all four relationship words mentioned may be used for the $2^{\text {nd }} p$. without any indication of person. If it is necessary to stress the possessive, however, the III ${ }^{\text {rd }}$ series is used here also, e.g., ana, wrj ana, "thy mother"; $a k a$, wej aka, "thy elder brother"; etc.

Lastly it should be noted that in several cases nowadays younger more regular forms appear besides these irregular, but more normal, ones. This may be due to a growing modernization, reflected in the language as well as in other spheres of life.

\section{4. The Verb.}

The Sentani verbal system is extremely complicated. A verbal form consists of one or two verbal roots to which may be added affixes for person (including number) both for the subject and the object (direct or indirect), mood, tense and aspect. The only prefix in use is the negative $ə$-. These facts, together with the frequent contraction of affixes, justify the analysis of the verbal structure on the basis of root plus affixes only, without making distinction between suffixes and infixes, and without introducing the notions of "stem" and of "immediate constituents" which would in most cases hardly be a simplification.

Structurally three principal types of verbal forms can be distinguished:

(1) primary forms, which are formed without an aspectual affix ;

(2) secondary forms, which contain an aspectual affix; and

(3) composite forms, which contain two verbal roots.

In the last category two types can be distinguished:

(a) the two roots are different, the first of them indicating a movement and each being inflected differently, in which case the compound denotes a sequence of events;

(b) the two roots are the same; this is the case of repetition of root forms indicating the gerund. 
An apparent third possibility of composition of similar roots in inflected forms other than that mentioned in (b), is really that of a verbal root indicating movement, which takes what seems to be originally a bound variant of the same root as an aspectual affix and thereby stresses the direction of that same movement (see III.4.4.1). This belongs, therefore, in the category of secondary forms of (2) supra.

Repetition of fully and independently inflected verb forms is syntactical and does not belong in this chapter (see III.2.2 and V.6).

In the categories of non-composite, i.e., primary and secondary, forms alone, a simple calculation will show that the number of theoretically possible verbal forms, including all moods, tenses and aspects, and including both forms with and without object affixes, amounts to more than 4,000, of which the indicative alone accounts for some 2,500. Naturally these possibilities do not all occur for every single verb, and some have similar forms for dual and plural object affixes. But the calculation shows clearly enough that the actually possible forms do number some thousands.

The following table gives a schematic conspectus of the verbal system as far as non-composite forms are concerned:

\begin{tabular}{|c|c|c|c|}
\hline \multirow{8}{*}{$\begin{array}{l}3 \text { persons, each } \\
\text { in sg., du. and } \\
\text { pl., and for both } \\
\text { subject and ob- } \\
\text { ject }\end{array}$} & Mood & Tense & \multirow{11}{*}{$\begin{array}{l}\text { secondary forms } \\
\text { derived with } \\
\text { apectual affixes } \\
\text { for goal deter- } \\
\text { mination }\end{array}$} \\
\hline & \multirow{5}{*}{ Indicative } & Present & \\
\hline & & Imperfect & \\
\hline & & Aorist & \\
\hline & & Habitualis & \\
\hline & & Future & \\
\hline & Adhortative & & \\
\hline & Conditional & - & \\
\hline \multirow{3}{*}{$\begin{array}{l}2^{\text {nd }} \text { p.s., du., pl. } \\
\text { subject; all per- } \\
\text { sons for object } \\
\text { uninflected }\end{array}$} & & & \\
\hline & Vetative & & \\
\hline & Negative & uninflected & \\
\hline
\end{tabular}

Examples: root a-, "go"; a- $j$, "go thou!" (adhort. 2 p.s.); a-le, "he goes" (pres.); a-j-de, "they two go" (pres.); a-wo-le, "he went" (imperfect); $\partial-k e$, "he went" (aorist); $\partial-d \partial-l e$, "I shall go" (future); $e-j-j a-l e$, "he uses to go" (habitualis); root folo-, "cut"; folo-w-ko-k-a-le, "I cut (something)" (aorist with aspectual affix -ko-); folo-w-no-ko-k$a$-le, "I have cut something for him" or "I have cut it" (with obj. aff. 3 p.s.); folo-w-di-ke, "he cut upwards" (with asp. aff. -di-); etc. 


\section{4. 1. The verbal root.}

The base of the verbal form, the root, is strictly speaking, a bound form, although it sometimes seems to occur in quasi-free position in certain forms of the gerund and the composite adhortative. But even here it is not really free, being restricted to repeated or composed forms, or forms with aspectual affix. Otherwise the form of the root can be best recognized from certain forms of the adhortative, e.g., the $2^{\text {nd }}$ p.s., which ends in $-j$, the $2^{\text {nd }}$ p. pl., which ends in $-m$, or the $3^{\text {rd }}$ p.s. in -w; e.g., a-j, "go thou !" a-m, "go you!"; " $a-\imath$, he must go!"; etc. However, as we have already said (cf. II. 4.1), verbal roots of more than one syllable ending in $-a$, preceded by one of the consonants allowed as syllable finals, tend to be treated as if they really ended, not in $-\partial$, but in this consonant, thus presenting bound allomorphs of such roots occurring in positions where a syllable closed by a consonant is no objection; cf. the examples given in II. 4.1.

The morphophonemic rules for the final vowel of the root in contact with a following flexional affix vowel are as follows: front vowel + $a>\varepsilon$; back vowel, $a$ and $\partial+a>a$; all vowels $+\partial$ absorb $\partial$.

No verbal root ends in the high vowels $i$ or $u$, apart from the variants, mentioned in II. 3 (phonemes /w/ and /j/), of uwa-, wa- and $j e-$. Examples: root je-, "climb": 1 p.s. pres. jele $<{ }^{*} j e-a l e$; root $b \varepsilon-$, "seek": 1 p.s. pres. $b \varepsilon l e$; root $j a$-, "sink, drop": 1 p.s. pres. jale; root mo-, "come": 1 p.s. pres. male; root ho-, "slay": 1 p.s. pres. hale $<* h o-a l e$; roots $j e-, b_{\varepsilon-}, m_{\partial-}, j a-$ and $h o-: 3$ p. du pres. jejde, bzjde, majde, jajde, and hojde (with ending -ajde); etc.

\section{4. 2. The Moods.}

There are five moods: the indicative, with the uninflectable negative, the imperative-adhortative (here named adhortative only), with the vetative (limited to the $2^{\text {nd }}$ p.s., du. and $\mathrm{pl}$. as far as the subject is concerned), and the conditional or optative (here named conditional).

The sign of the indicative is $-l e \sim-d e \sim-b e$, the morphophonemic distribution of these three allomorphs over the various forms following the obligatory "heterophonemic" variation in certain positions of $/ 1$ and $/ \mathrm{d} / \mathrm{as}$ far as the former two are concerned, while -be occurs after labials $(b, m$ and $w$, of which $b+-b e>-b e$ ). The modal sign follows, generally speaking, the person subject affix and is the final element in the verbal structure. However, in the $2^{\text {nd }}$ p.s. of the present, the imperfect and the primary and secondary forms of the aorist and the 
habitualis, as well as in the $2^{\text {nd }}$ p. du. of the primary and secondary forms of the future, the indicative mood sign coincides with the person subject affix, $(-j)-\varepsilon$ and $-b e$ respectively. In the $2^{\text {nd }}$ p.s. of the primary and secondary aorist, moreover, the combined mood + person ending contracts with the tense affix to $-k \varepsilon$. In the $3^{\text {rd }}$ p.s. of the primary aorist and in all persons, except the $1^{\text {st }}$ and $2^{\text {nd }}$ p.s., of the secondary aorist, the modal sign coalesces with the tense affix to $-k e$, but perhaps reappears as $-w$ - in the singular persons of the secondary aorist between root and aspect affix (see III. 4.6). For the morphophonemic rules of the indicative sign in contact with object affixes, see otherwise III. 4. 7.8

Examples for primary forms : ma-le, "I come"; $m \partial-j-\varepsilon$, "thou comest";

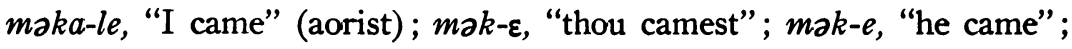

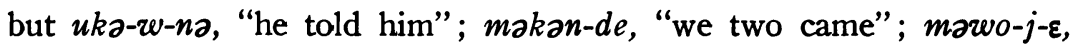
"thou camest" (imperf.); mawoj-de, "they two came" (imperf.); mawaw-be, "you (pl.) came"; ma-be, "you two will come" (fut.); mam-be, "you (pl.) will come"; mokojja-le, "I use to work all the time" (habit.); mokojja- $j-\varepsilon$, "thou usest to work all the time"; etc. And for secondary forms: howboka-le, "I killed (something)" (aor.);

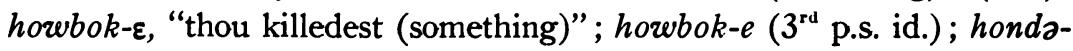
bok-e, howbok-e, hojbok-e, etc. $\left(1^{\text {st }}, 2^{\text {nd }}, 3^{\text {rd }}\right.$ p. du. etc. id.); mokojbo$j a-l e$, "I do, make (something) every time" (second. habit. or iterat.); mokojbojow-be (2 p. du. id.); hodabon-de, "I shall kill (something)"; howbon-de ( $2^{\text {nd }}$ p.s. id.); hobo-be $\left(2^{\text {nd }}\right.$ p. du. id.); etc.

In composed verbal forms the second constituent of the compound carries the indicative sign, and this follows either the same rules as for the present, the habitualis or the imperfect on the one hand, or those for the secondary aorist or the secondary future on the other, according to whether the compound is one of the $\mathrm{II}^{\text {nd }}$ or one of the $\mathrm{I}^{\text {tt }}$ category described in III. 4.9. For examples see $i b i d$.

The sign of the adhortative is zero; e.g., mado, "let me come"; maj, "come thou!"; ma, "let us two come"; etc. For the adhortative in secondary forms, see III. 4.4; and in composite forms III.4.9.

The conditional 9 has only endings of its own in the singular, both primary and secondary, and in the secondary dual and plural, the primary forms of the dual and plural being supplied by the present of the indicative. The sign is $b$ in all forms, except the $1^{\text {tt }}$ and $2^{\text {nd }}$ p.s.

8 A much more regular occurrence of the indicative mood sign is found in the Nafri language, which is very instructive for the situation in Sentani too.

9 This mood, or at least its $2^{\text {nd }}$ p.s. which is quite identical in the two languages, is used as a common imperative in Tanah Merah. 
In the $2^{\text {nd }}$ p.s. it is $m$; in the $1^{\text {st }}$ p.s. it seems to coincide with the indication of the person; e.g., $\partial-l e$, "should I go, I would go"; $\partial-j-m \varepsilon$, "shouldst thou go"; $\partial-w-b e$, "should he go"; and with asp. aff.

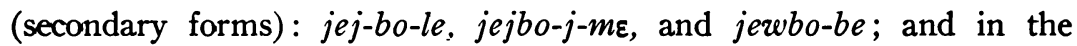
secondary plural : jendabo-be $\left(1^{\mathrm{st}}\right.$ p. du. $) ; j \varepsilon j b o-b e(<* j e-a j-)\left(3^{\text {rd }}\right.$ p. pl.) ; etc., these secondary forms of the plural being formed after a similar structural model as the secondary aorist, the ending -be corresponding to $-k e$ in the latter (see III. 4.6).

The sign of the negative is the prefix $\partial$ - in combination with the affix (or root extension) $-j$. If the initial of the root is itself $\partial$, the prefix is either added by means of the junction consonant $-j-$, or it contracts with the $a$ of the root which is then somewhat lengthened and takes the stress. The relevant element is this stress, not length. In secondary forms, the aspectual affix which follows the root extension $-j-$, is again followed by this element in addition. The negative thus formed, is not otherwise inflected; e.g., $\partial-^{\prime} m \partial-j$, "not come" ; $\partial-h a b \partial-j$, "not hit"; but $\partial-j-\partial-j$, "not go"; $\partial-j-a l \partial-j$, but also 'ala- $j$, "not speak", as opposed to $\partial^{\prime} l \partial j$, "speak thou!" (adhort. 2 p.s.); da a-hojboj, "I do, did, shall not kill (something)"; na a-j-anajkoj, "he does, did, will not eat (it)"; $\partial-d u w \partial-j-o-j$, "it does, did, will not fall down"; etc.

The vetative is only partly inflected, viz. for the $2^{\text {nd }}$ p.s., du. and pl. of the subject, but for all persons of the object. It is formed by prefixing the same $\partial$ - or $\partial-j$ - to the $2^{\text {nd }}$ p.s., or pl. of the adhortative, in combination with the enclitic particle $j \varepsilon$, following the person affix and assimilating to it retrogressively to $-m \varepsilon$ after the $-m$ of the $2^{\text {nd }}$ p. du., pl. (in the $2^{\text {nd }}$ p.s. the resulting $-j j$ - is usually pronounced $-j \not g$ - in accordance with what has been said in II. 3 for $/ j /$ ). In secondary forms, the aspect affix, which follows the person affix, precedes the particle, but the person affix intervenes again between aspect affix and particle. Examples : $\partial-m \partial-j-j \varepsilon$, “do (sg.) not come!” $\partial-m \partial-m-m \varepsilon$, “do (du., pl.) not come!"; $\partial-j-a n \partial-j-j \varepsilon$, "do not eat!"; $\partial-h o j-b o-j-j \varepsilon$, "do not kill";

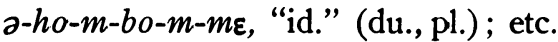

\section{4. 3. The Tenses.}

There are five tenses: the present, the habitualis, the imperfect, the aorist and the future. Tense distinctions are restricted to the indicative; they are unknown in the other moods.

The sign of the present is zero, this tense being recognizable by the "actual" subject person affixes only. The habitualis is characterized by $-j a-$, added to the root extended with $-j-$, the imperfect by $-w o-$, 
and the aorist by $-k a-$. The future has zero, like the present, and is distinguished from it by the "eventual" person subject affixes only, except for the secondary future, which shows, in addition to this, a constant $n$ (in the $2^{\text {nd }} \mathrm{p}$. pl. $m$ before $b$ ) preceding the indicative sign in all persons other than the $2^{\text {nd }} \mathrm{p}$. du. which has zero before $b$. Except for this secondary future and the secondary aorist, the tense elements precede the person affixes for the subject. Their vowel follows the same morphophonemic rules as that of the root, when in contact with the initial vowel of a following affix (see III.4.1). The tense affixes contract with the person affix and/or the modal sign in certain forms of the aorist as described in III.4.2. The affix -ja- of the habitualis often assimilates to $-j o$ - after a syllable containing $o$. Examples: $m$-ale, "I come" (pres.); mə-le, "he comes"; mo-k-ale, "I came" (aorist); $m ə-k-\varepsilon$, "thou camest" (aor.); mə-w-ale, "I came" (imperf.); mə-wo-le, "he came" (imperf.); mə-də-le, "I shall come" (fut.); mə-le, "thou wilt come"; ma-n-de, "he will come"; ma-naj-de, "they two will come";

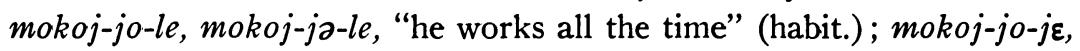

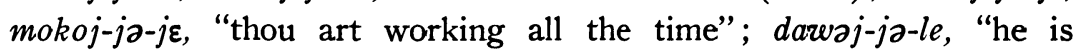
opening all the time"; dawaj-bo-j-a-le, "I use to open every time" (habit. second. form, or iterat., with asp. aff. -bo-); etc. For the secondary aorist and future see further III. 4. 6.

\section{4. 4. Secondary (aspectual) forms.}

The tenses, besides indicating a time element, also have other properties which belong in the aspectual sphere. We have named them "tenses" because of that time element, and there is no more objection to this than there is to the use of that term in other languages in which time is not the only characteristic feature of the categories concerned. This has, moreover, the advantage that we can use the term "aspectual" for a category of affixes with which we shall now deal, and which, though not aspectual in the sense accepted for certain better known modern languages, do determine the aspect of a verb as to its goal. We shall go into the temporal and aspectual features of both tenses and aspectual forms in greater detail in the chapter on Syntax (see V.9). Here suffice it to add that I had named the latter forms "modal" in my Notes on Sentani Grammar, mentioned in the Introduction, because they "modify" the verb in the indicated sense. But this term is equivocal in view of the real "moods" which Sentani possesses. Also the aspectual affixes are not restricted to any one mood, but occur in all moods, including the negative and the vetative, and are even found in the 
gerund. We shall name the forms with aspectual affixes secondary forms as against the primary forms without them.

Morphophonemically the aspectual affixes are distinct from the other verbal affixes, for both mood, tense and person, in that their vowels are practically always constant, although this may be largely due to the fact that in the verbal structure they happen to be always followed by a consonant. 10 Only -bo- in quick speech sometimes contracts with the habitualis -jo- to -bojo-, bijo- for the more normal -bojo-. If the aspect affix begins with a vowel and the preceding flexional element of the verb ends in a vowel, the two vowels are not contracted, but linked by the consonant $-j-$, e.g., $a w a-j-\partial m$ (for *aw-a-ว-m), "let us two row off". In the indicative the aspect affix immediately precedes the sign for tense, which means for the secondary future preceding its $-n$ - in all persons except the $2^{\text {nd }}$ p. du. where, the tense sign being $z e r o$, it precedes the mood ending, e.g. ho-do-bo-nde, "I shall kill (something)", but ho-bo-be ( ${ }^{\text {nd }}$ p. du.). In the habitualis, which, with the aspect affixes, forms a kind of iterative (cf. V.9), the preceding root has the usual $-j$ - extension, e.g., dar' $-j-b o-j-a l e$, "I am used to open (it) every time". In the adhortative the aspect affix is found at the extreme end of the verbal structure, except in the $1^{\text {st }}$ p.s., du., pl. in which an additional $-m$ follows it, e.g., ho-j-bo, "kill thou (some-

10 Historically speaking, the aspectual affixes, with the exception of $-n u$, may well have been short verbal roots, and the secondary forms may really have been composite forms originally. This is almost certain for some of the directive affixes which, with the exception of $-d i$ - (verbs never end in a high vowel, apart from the variants mentioned in III.4.1), still occur as verbal roots as well. And some of the objective affixes, such as $-k o-$ and $-b o-$, may have had something to do with verbs as ko-, "do, act", and bo-, "aim, beat", although these meanings are not now recognizable. However, the secondary forms cannot now be regarded as composite verbs in the sense of III. 4.9. The reasons are: (1) they all follow the same structural rules as forms with the reflexive affix $-n u$-, which is certainly not a verb, but seems to be derived from na $u>n-u$, "his body, his person, his self", while, moreover, for many of them there is no comparable verbal root in existence; (2) containing an aspectual affix, they cannot take a second aspectual affix, whereas the composite forms of III. 4.9 can take such an affix ; (3) they can consist of verbal root with directive affix identical to the root; (4) the composite forms of III. 4.9 place the personal object affix partly in similar, but partly in different positions from those it occupies in the secondary forms; (5) the personal subject affixes are in some persons different from those in the composite forms; (6) the aspectual affix always follows its verbal root, as do all verbal affixes (except the negative), whereas the verbal roots which correspond to directive affixes always precede the other verbal constituent when they enter into the composition of III.4.9. 
thing)!", but ho-do-bo-m, ho-da-bo-m, "let me kill (s.)", and $h-a-b o-m$ $\left(1^{\text {st }}\right.$ p. du. $)$ and ho-ma-bo-m ( $1^{\text {st }}$ p. pl.). In the conditional the aspect affix immediately precedes the ending $-b e$ in all persons except the $1^{\text {st }}$ and $2^{\text {nd }}$ p.s., in which it precedes the ending -le and $-m \varepsilon$ respectively, with an intervening repeated person sign $-j$ - in the latter form, e.g., $j e-w-b o-b e$, "should he become" but $j e-j-b o-l e\left(1^{\text {st }}\right.$ p.s.) and $j e-j-b o-j-m \varepsilon$ $\left(2^{\text {nd }}\right.$ p.s. $)$. In the negative, the vetative and the gerund the aspect affix occurs immediately after the $-j$ - of the root extension, or, in the case of the vetative, the $-j$ - of the $2^{\text {nd }}$ p.s., which $j$ is, in negative and vetative, repeated after the aspect affix; e.g., $a-h o-j-b o-j$, "not kill" (negative); $a-h o-j-b o-j-j \varepsilon$, "do not kill" (vetat. $2^{\text {nd }}$ p.s.); but $o-j-b o$, "descending" (gerund).

There are four types of aspect affixes, viz.:

(1) those that determine the action of the verb as to its direction, either in space or in time, and can, therefore, occur in intransitive verbs; we shall call them directive;

(2) those that determine the action of the verb as to its object, and therefore cannot occur in intransitive verbs; we will call them objective ;

(3) the medial affix -bo- which indicates that the action is done for or in favour of the subject itself or happens by itself, and hence may be both transitive and intransitive; sometimes this function is, however, not so clear;

(4) the reflexive affix - $n u$ - which functionally could be compared with a personal object affix, but which word-structurally follows the same rules as the aspect affixes, can take a pronominal object affix in addition (notably for the indirect object), and hence is treated here.

\section{4. 4. 1. Directive affixes.}

The directive affixes are:

(1) -ma-for a movement towards the speaker or a "coming home" (in space), or an action, lasting in its effect up to the present time;

(2) -a- for a movement away from the speaker (in space) or an action, lasting in effect away in time, i.e., without a definite or definitely known end;

(3) -ho- [ $\sim-s o-] \sim-f o-$ for a movement "across and away", going over, going off ;

(4) -o- for a downward, descending movement; 
(5) -me- for a descending movement away, especially from the (high) shore or island to the waterside;

(6) -di- for an upward, climbing movement.

Examples: dawaw-ma-ke, "he brought it here" (aor.); dawam-ma$n d e$ (<dawan-mə-), "he will bring it here"; kow-a-ke, "he acted, did (away), started acting onwards"; awaj-ma-ke, "they two rowed home"; nakaj-a-ke, "they two started living on"; aj-a, "go away thou!"; dilow-fo-ke, "he dived over, across (e.g. the edge)"; diloj-so-ke (id. $3^{\text {rd }}$ p. du.); diloda-ho-nde, "I shall dive over"; okow-o-ke, "he poured down"; oj-o, "descend down thou!"; folow-di-ke, "he cut upwards"; nare-me-ke, "he embarked, put off (in a canoe)" (lit. "he stuck down-off'); etc.

\section{4. 4. 2. Objective affixes.}

The objective affixes are:

(1) -ko-, which envisages the action as active transitive and directed upon an object other than the subject. Often the object and/or the action itself is plural. Hence it can also be used in reciprocal actions, i.e., where both persons involved in the actions are at once subject and object;

(2) $-h i-[\sim-s i-] \sim-f i-$, which indicates a bringing together, uniting, collecting, connecting or fastening of the object or objects, but sometimes also a disuniting, disconnecting of what belongs together, while often the original meaning is not clear any more;

(3) $-h a-[\sim-s a-] \sim-f a-$, which indicates a putting into something of, or filling something with, the object, but sometimes also the taking out of something which belongs in something.

Examples: molow-ko-ke, "he made, worked on (something), planted (a garden)"; kajew-ko-ke, "he split, cut (the sago)"; awaj-ko-ke, "they two struck (the paddles), they rowed"; anaw-ko-ke, "he ate (food)";

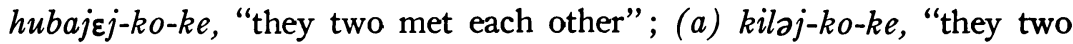
had words (a) with each other"; alaw-ko-ke, "(after) he had spoken (those words)"; adilaw-fi-ke, "he collected"; molow-fi-ke, "he fastened (something)"; honoj-na-hi, "lie on it!"; bukaw-fi-ke, "he left, took his leave"; anaj-si, "drink thou!" (specialized meaning as opposed to anaj-ko, "eat"); naj-sa-ke, "they stuck into"; ajerw-fa-ke, "it jammed, got stuck in, between"; okow-fa-ke, "he poured into"; balaj-sa, "open, unpack (something) to take out what is in it"; budelaj-sa, same meaning; etc. 


\section{4. 4. 3. The medial affix.}

Examples: ow-bo-ke, "it dropped down (by itself)"; hilaj-bo, "be silent"; walew-bo-ke, "he came back to life"; akow-bo-ke, "he descended"; (holoboj) mokow-bo-ke, "he made (a sack) for himself"; (ja) hew-bo-ke, "it became day, light" (lit. "day was hung"); (u) jew$b o-k e$, "it had become (empty)" (from je-, "give" + -bo- = "become").

\section{4. 4. 4. The reflexive affix.}

Examples : $a j-n u$, "raise self, rise, stand up"; azv-nu-ke, "he rose";

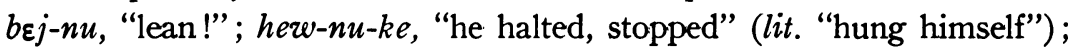

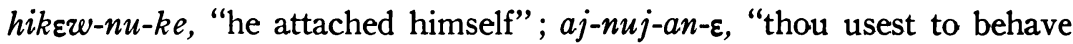
thyself toward him"; etc.

\section{4. 5. Indication of person (with number) for the subject in primary forms.}

The indication of person (with number) for the subject takes place in different manners for primary and for secondary forms. In primary forms the affixes for the subject person can formally be divided in two main categories, which can be termed (1) the actual and (2) the eventual. The two are, however, not always clearly separated, and there is some interpenetration. The "actual" forms are found in those tenses of the indicative which indicate that an action is actually taking place in the present, or has actually taken place in the past, viz. the present, the habitualis, the imperfect and the aorist. The "eventual" affixes occur in those forms which indicate that an action will happen or is expected, supposed, desired or forbidden to happen, viz., the future, partly the adhortative and the conditional, and the vetative. The deviations in the adhortative are the $3^{\text {rd }}$ p.s., du and pl., which are similar to the "actual" forms, while in the conditional the deviation in the $1^{\text {st }}$ p.s. may well be so only in outward appearance, because the $-d$ - element of the "eventual" $1^{\text {st }}$ p.s. may be concealed in the $l$ of the ending -le. The $2^{\text {nd }}$ p.s. has elements of both categories; the $3^{\text {rd }}$ p.s. is similar to the "actual".

The most striking characteristic feature of the "actual" and the "eventual" person affixes as distinct from each other is, that, while the former seem to have little or no formal relation with the absolute personal pronouns nor with the personal object affixes, the latter for the greater part do show such a relation. This is, as far as the future is concerned, clearly the case at least for the $1^{\text {st }}$ p.s. and pl., the $2^{\text {nd }}$ p. du. and pl., and (with the absolute pronoun, not the object affix) for the 
$3^{\text {rd }}$ p.s., du. and pl. Even for the $2^{\text {nd }}$ p.s. there is a possibility that a $w$ has been dropped before the modal ending -le; this - $w$ - at least appears, in forms with an incorporated person object affix, immediately before it, and is also found in the secondary future.

The following table gives the two categories of subject affixes:
Person
I. Actual
II. Eventual

a. future

b. adhortative

c. conditional

$1^{\text {st }}$ sg. $\quad-\mathrm{a}-$

$2^{\text {nd }}$ sg. $\quad-(\mathrm{j})-\varepsilon$

$3^{\text {rd }}$ sg. $\phi ;-w-$

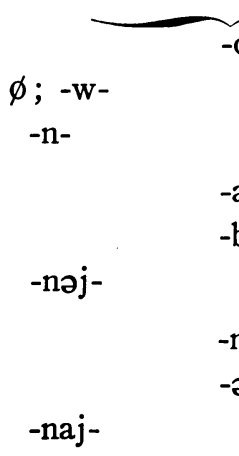

-də-

$\varnothing$

$1^{\text {st }}$ du. -ən- ; -ə-(j)-

$2^{\text {nd }} \mathrm{du}$. -əw-

$3^{\text {rd }}$ du. $\quad-\partial j-$

$-b-$

$1^{\text {st }}$ pl. $\quad$-an-; -a-(j)-

-ma-

$2^{\text {nd }} \mathrm{pl} . \quad-\mathrm{aw}-$

$3^{\text {rd }} \mathrm{pl} . \quad-a j-$

$-2 \mathrm{~m}-$

These person affixes, as far as the categories I and II (a) are concerned, precede the modal element for the indicative according to the morphophonemic rules stated for the latter (cf. III.4.2). As for II (b), the modal sign for the adhortative being zero (and that for the vetative, which otherwise is similar to the $2^{\text {nd }}$ persons of the adhortative, being a prefix and a particle), these affixes are, of course, final. An exception is the $2^{\text {nd }} \mathrm{p}$. du. of the adhortative which has $-b u, b$ not being admitted as final. In accordance with the morphophonemic rules already stated for the treatment of final root vowels in contact with following affix vowels, the initial o-vowels in these person affixes too drop after preceding vowel, while the initial $a$-vowels persist after preceding $a, \partial$ or back vowel, and contract to $\varepsilon$ with a preceding front vowel. In the $2^{\text {nd }}$ p.s. "actual" $\varepsilon$ is linked to a preceding vowel by the juncture consonant $-j$ - The allomorphs - 2 - and - $a$ - for the "actual" $1^{\text {st }}$ p. du. and pl., which occur only in combination with certain object affixes, take this same juncture consonant $-j$-, when followed by a vowel, and then are similar to the $3^{\text {rd }}$ p. du. and pl. The allomorph - $w$ - of the $3^{\text {rd }}$ p.s. "actual" too occurs before a person object affix. Examples: $\dot{m}$-a-le, "I come" (present);

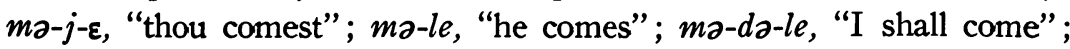
ma-da, "let me come" (adhort.); ma-n-de, "he will come"; ma-w, "he must come"; ma-w-be, "you two come" (present); ma-be $\left(<{ }^{*} m ə-b-b e\right)$, 
"you two will come"; ma-bu, "come you two!" (adhort.); ma-k-a-le, "I came" (aorist); ma-ka-j-de, "they two came" (aor.); mok-a-le, "I make, do, work" (present); moko-n-de, "he will make"; moko-bu, "make you two!" (adhort.); etc. For examples of the allomorphs in use with object affixes, see III. 4.7-8.

\section{4. 6. Indication of person (with number) for the subject in secondary forms.}

Person for the subject in secondary forms is indicated in different ways according to tense or, as the case may be, mood; and, for each tense or mood, according to person and/or number.

In the secondary habitualis or iterative the position of the person subject affix is regular throughout, following the tense affix and preceding the mood sign. In the aorist and in the conditional the indication of person for the subject differs according to number, the affix following the tense sign in the regular manner of III. 4. 3 in the singular, but following the root and preceding the aspect affix in the dual and plural. In addition, in the singular persons of the aorist a $-w$-immediately follows the root and precedes the aspect affix, the dual and plural having, like the $3^{\text {rd }}$ p.s., throughout the ending $-k e$ following the aspect affix. However, the $3^{\text {rd }}$ p. du. and pl. have a younger, more regular, form besides, in which the regular endings $-a j-d e$ and $-a j-d e$ are added pleonastically after the tense sign -ka-, thus: $-k-\partial j-d e,-k-a j-d e$. This $-w-$ may be a syllable-final allomorph and perhaps even a phonetic derivative of the $l$ of the indicative sign -le. The ending $-k e$ is the contraction of tense and mood signs $\left(<*_{-} k(\partial)-l e\right)$, already mentioned in III. 4.2. The singular persons of the conditional have $-j$ - immediately following the root in the $1^{\text {st }}$ and $2^{\text {nd }}$ p.s., and $-w-$ in the $3^{\text {rd }}$ p.s., the dual and plural having, like the $3^{\text {rd }}$ p.s., throughout the final $-b e$, as described in III. 4.2. In the $1^{\text {tt }} \mathrm{p}$. du. and pl. both aorist and conditional have -anda- and -ando- respectively instead of the "actual" -an- and -an-. With the forementioned restrictions and exceptions, the personal affixes of aorist and conditional otherwise correspond to the "actual" and "eventual" forms of the preceding section respectively. Examples: (habitualis) mokoj-bo-j-a-le, "I am

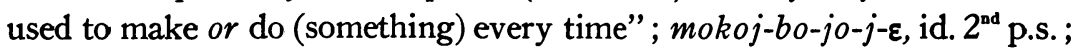
mokoj-bo-j-aj-de, id. $3^{\text {rd }}$ p. pl.; (aorist) ho-w-bo-k-a-le, "I killed

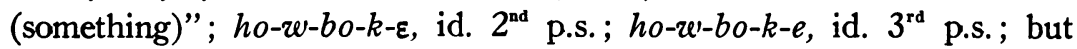
ho-ndo-bo-k-e, id. $1^{\text {st }}$ p. du.; h-anda-bo-k-e, id. $1^{\text {st }}$ p. pl.; h-aj-bo-ke or $h-a j-b o-k-a j-d e$, id. $3^{\text {rd }}$ p. pl.; (conditional) je-j-bo-le, "should I 
become"; $j e-j-b o-j-m \varepsilon$, id. $2^{\text {nd }}$ p.s. ; je-w-bo-be, id. $3^{\text {rd }}$ p.s. ; but $j e-j-b o-b e$ $\left(\right.$ for $\left.*^{*} j-a j-\right)$, id. $3^{\text {rd }}$ p. du. ; $j \varepsilon-j-b o-b e$ (for $* j e-a j-$ ), id. $3^{\text {rd }}$ p. pl.; etc.

In the future the subject person affix throughout follows the root and precedes the aspect affix, the secondary future tense sign $n$, immediately followed by the indicative mood affix $l e \sim d e \sim b e$, occurring in final position in all persons except the $2^{\text {nd }} \mathrm{p}$. du. and $\mathrm{pl}$. In these persons the subject affix is found after the aspect affix and preceding the tense affix $\left({ }^{*} b-b e>b e\right.$ in the dual and $m$-be in the plural), but in the $2^{\text {nd }} \mathrm{p}$. pl. in addition to the post-radical position $\left(^{*}-a m-k o-m-b e\right.$ $>-a n-k o-m-b e)$. Hence in the secondary future all persons, except the two just mentioned, end, like the $3^{\text {rd }}$ p.s., in asp. aff. $+-n d e$, while in the secondary aorist all persons except the $1^{\text {st }}$ and $2^{\text {nd }}$ p.s. end, like the $3^{\text {rd }}$ p.s., in asp. aff. $+-k e$, and in the conditional in asp. aff. $+-b e$. The personal affixes of the secondary future correspond to the "eventual" forms, but in the $2^{\text {nd }}$ p.s. the allomorph $-w$ - of zero is used. For the $1^{\text {tt }}$ p.s. - do- a variant $-d o$ - occurs when surrounding affixes have $o$ vowels, but it is not obligatory.

In the secondary adhortative the same principle prevails as in the secondary future, the person affixes, which follow the root and precede the aspect affix, corresponding to the "eventual" forms, series II (b), except for the $1^{\text {st }}$ p.s., du., pl., which have an additional $m$ following the aspect affix, and the $2^{\text {nd }}$ p. du. which has zero instead of $-b u$ (or perhaps loss of $b$ before the consonant of the aspect affix).

For the vetative lastly, see III. 4. 2, last para.

Examples: (future) ho-də-bo-nde or ho-do-bo-nde, "I shall kill (something)"; $h$-a-bo-nde, id. $1^{\text {st }}$ p.du.; but ho-bo-be, id. $2^{\text {nd }}$ p. du.; $h o-m-b o-m-b e$, id. $2^{\text {nd }}$ p. pl.; or with asp. aff. $-k o-: h o-n-k o-m-b e$ (for $h o-m-k o-)$; (adhort.) ho-j-ko, "kill thou!"; ho-n-ko, id. $2^{\text {nd }}$ p. pl. (for $h o-m-k o)$; but ho-do-ko-m, "let me kill"; $h-a-k o-m$, id. $1^{\text {tt }}$ p.du.; $h o-m a-k o-m$, id. $1^{\text {st }}$ p. pl.; etc.

\section{4. 7. Indication of person (with number) for the object in primary forms.}

The object in primary forms is indicated by person affixes which, as a rule, follow in the verbal structure the person affix for the subject and precede the affix for mood. This means that if the person subject affix is zero, the object affix immediately follows the tense sign, and if this is zero too, the root. If the sign for mood is zero, as in the adhortative, the object affix naturally stands at the extreme end of the verbal structure. The following peculiarities should, however, be noted. 
In the $2^{\text {nd }}$ p.s. subject form the object affix immediately precedes the combined mood + subject person ending $-\varepsilon$ in those forms of the indicative where this occurs (see III. 4.2). In the $3^{\text {rd }}$ p.s. subject form the object affixes of the $1^{\text {st }}$ and $3^{\text {rd }}$ p.s., du., pl. are in the indicative placed at the extreme end of the verbal structure, preceded by the $-w$ allomorph of the $3^{\text {rd }}$ p.s. "actual" for the subject (see III. 4. 5), the mood sign being omitted altogether. Omission of this mood affix is usual in the $2^{\text {nd }}$ and $3^{\text {rd }} \mathrm{p}$. du., pl. subject forms of the present and the imperfect, if the object affix is in the $1^{\text {st }}$ p.s., du., pl., or in the $3^{\text {rd }}$ p.s., du., pl.; but for the $3^{\text {rd }}$ p. du., pl. object forms it is not a strict rule and these forms are found both with and without a final -le for the indicative mood.

If the object affix is in the $2^{\text {nd }}$ p.s., du., pl., the preceding "actual" subject affixes for the $1^{\text {st }} \mathrm{p}$. du., pl. then have the allomorphs - $\partial$ - and $-a$ - respectively linked with following vowel by $-j$ - (see III. 4 . 5), whence the forms for these persons are wholly identical with the forms of the $3^{\text {rd }}$ p. du., and pl. subject (which have $-a j$ - and $-a j$ - respectively). If the object affix is in the $3^{\text {rd }}$ p.du., pl. the $n$-element in the "actual" forms - $\partial n$ - and -an- of the $1^{\text {st }}$ p. du., pl. may assimilate to the object affix $m i$ to $-m m i$ or may be separated from it by $\partial$, thus: $-n \partial-m i$.

In the adhortative the $1^{\text {st }}$ p.s., du., pl. subject forms add the same final $-m$ after the object affix, as we also found added after the aspectual affixes in secondary forms of the adhortative (cf. III.4.4), and similarly the $2^{\text {nd }}$ p. du. subject form has the same zero (or loss of $b$ ) for the subject affix as we found in the secondary adhortative (cf. III. 4. 6).

In the singular of the conditional the object affix precedes the peculiar forms of subject person + mood $-l e,-m \varepsilon$, and $-b e$ of the $1^{\text {st }}, 2^{\text {nd }}$ and $3^{\text {rd }}$ p.s. respectively (cf. III. 4. 2).

The vetative lastly (the negative is, of course, uninflected here too), shows the same extension of the object affix with an additional $-m$ as we have seen in the $1^{\text {st }}$ p.s., du., pl. of the adhortative. As in the adhortative the extended affix is placed after the subject affix for the $2^{\text {nd }}$ p.s. $(j)$ or pl. $(m)$; the following emphatic particle $j \varepsilon$ then assimilates retrogressively to the $-m$-extension and becomes $m \varepsilon$.

The object affixes are the following:

$\begin{array}{cccc}\text { Person } & \text { Singular } & \text { Dual } & \text { Plural } \\ 1^{\text {st }} & \mathrm{d} & \mathrm{m} & \mathrm{m} \\ 2^{\text {nd }} & \mathrm{w}, \mathrm{j} & \mathrm{b} & \mathrm{m} \\ 3^{\text {rd }} & \mathrm{n} & \mathrm{mi} & \mathrm{mi}\end{array}$


As has already been remarked in connection with the subject person affixes (III. 4. 5), these affixes show, at least partly, a distinct formal relation with the "eventual" class of the subject affixes, and with the independent personal pronouns.

The distribution of the $w$ and $j$ allomorphs of the $2^{\text {nd }}$ p.s. object is as follows: $-j$ - occurs in all forms where it precedes the mood affix (which then has the allomorph $-d e$ ), i.e., when the subject is in the $3^{\text {rd }}$ p.s., du., pl. or the $1^{\text {st }}$ p. du., pl. of the present, the habitualis, the imperfect and the aorist, in all persons of the future and in the $1^{\text {st }}$ p.s. of the conditional; -w- occurs in the other forms, i.e. the small minority. The $2^{\text {nd }}$ p. du. object affix only occurs if the subject is in the $1^{\text {st }}$ or $3^{\text {rd }}$ p. sg. of the indicative tenses, except the future (in the $3^{\text {rd }}$ p.s. $-b-+\operatorname{mood}$ affix $-l e>-b e$ ). In the $1^{\text {tt }}$ and $3^{\text {rd }}$ p. du and pl. subject forms of the indicative tenses just referred to, and in all persons of the future, the adhortative and the conditional the $2^{\text {nd }}$ p. pl. object affix is used for the dual as well $(-m-+\operatorname{mood}$ affix $>-m b e)$.

Except for the $3^{\text {rd }}$ p. du., pl., only the consonants are given in the above table, because the vowels in the other persons are unstable and non-distinctive. The $i$ of the $3^{\text {rd }}$ p.du., pl. -mi-, however, when in contact with $a$ or $\varepsilon$, or a syllable in $a$, assimilates, progressively or retrogressively, to $\varepsilon$. Of the consonants the $-n$ - of the $3^{\text {rd }}$ p.s. may assimilate to $m$ if followed by $b$. In the $1^{\text {st }} \mathrm{p}$. du. of the future this $n$ is repeated and becomes -nan-. In the $1^{\text {st }}$ p.s. of the conditional the $2^{\text {nd }}$ p.s. object affix is also doubled and becomes - jaj- (if, at least, the first $j$ is not the juncture consonant).

The vowel of the affixes, though unstable and non-distinctive, except for the $3^{\text {rd }}$ p. du., pl., is basically $\partial$, but assimilates to $a$ in contact with a syllable containing $a$ or $\varepsilon$. Because of the limitations of consonant clusters the vowel may precede or follow the consonant, dependent on environment; e.g., waw-na, "he tells him"; wa-n-an-de (for *wa-an-

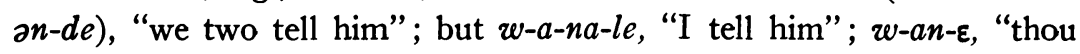
tellst him"; etc.

For a complete conspectus of all possible formations we refer the reader to the paradigmatic tables of chapter IV. Here we must content ourselves with some examples for illustration: hab-a-le, "I strike, beat,

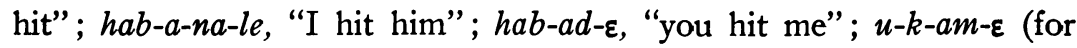

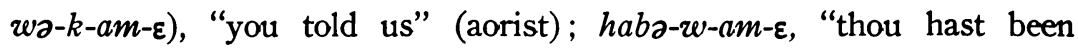
beating us" (imperfect); $u-k$-an-an-de, "we (pl.) told him" (aor.); wo-

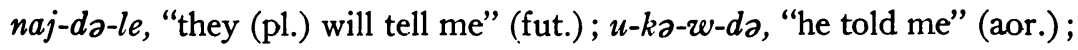
$u-w o-w-d a$, "you two have been telling me" (imperfect; for *wa-wo- 
aw-da) ; haba-w-aj-ma, "they (pl.) have been beating us (du. and pl.)" (for *habə-wo-aj-mə); hab-a-wa-le, "I hit thee" (present; with $2^{\text {nd }}$ p.s. obj. aff. -w-); but habo-j-de, "he hits thee"; hab-aj-aj-de, "we (pl.) (but also "they") hit thee" (with $2^{\text {nd }}$ ps. obj. aff. $-j-$-); habo-w-a-ba-le, "I have been hitting you two" (for *habo-wo-a-ba-le); haba-w-a-ma-le, "I have been hitting you (pl.)"; haba-wo-j-am-be, "we two (but also "they two") have been beating you (pl.)" (for *haba-wo-a-əm-be if the $1^{\text {st }}$ p. du. subj. is meant, and for *haba-zo-aj-am-be if the $3^{\text {rd }}$ p. du. subj. is meant); habə-w-aj-əm-be, "we (pl.) (but also "they-pl.") have been beating you (pl.)" (for *haba-wo-a-am-be and *haba-wo-aj-am-be respectively); hab-a-me-le, "I hit them" (for *habo-a-mi-le); hab-aj-mi-le or habajmi, "they (pl.) hit them" (present); $u-z w o-j-m i-l e$ or $u$-wo-j-mi, "they two have been telling them" (imperfect); hab-am-mi-le, "we (pl.) hit them" (for *-an-mi-); wa-j-na, "tell him thou!" (adhort.); wə-w-nə, "he must tell him" (adhort.); but $u-d \partial-n \partial-m$ or, contracted, $u-d \partial-m$, "let me tell him" (for *wə-də-nə-m); w-a-nə-m, "let us two tell him"; wa-na, "you two must tell him"; wa-n-na, "you (pl.) must tell him"

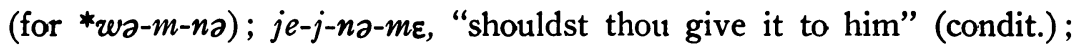
$j e-w-d \partial-b e$, "should he give it to me" (condit.); $a-w a-j-d \partial-m-m \varepsilon$, "do

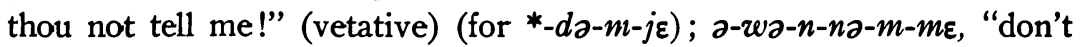

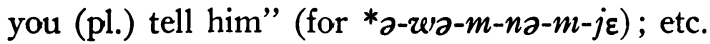

\section{4. 8. Indication of person (with number) for the object in secondary forms.}

According to the position the object affixes occupy in the verbal structure, three main types can be distinguished:

(1) the iterative (secondary habitualis) places all person object affixes after the tense sign -ja-, and, as the case may be, after the subject affix or in the ending, entirely in the same manner as the primary habitualis ;

(2) the adhortative and the conditional place all person object affixes, and the tenses of the indicative, except the iterative, place the $1^{\text {tt }}$ and $3^{\text {rd }}$ p.s., du., pl. object affixes, immediately before the aspect affix;

(3) the indicative, except the iterative, is irregular as to the position of the object affixes of the $2^{\text {nd }}$ p.s., du., pl., for which the following peculiarities should be noted:

The affix is usually, though not always, placed at once before the aspect affix and between the subject affix and the mood sign in the ending, according to the rules stated above for the $2^{\text {nd }}$ p.s., du., pl. object affixes in primary forms. It is thus indicated twice in the verbal 
structure, but with this additional peculiarity that the $2^{\text {nd }}$ p.s. has always $-w$-before the aspect affix even if it has $-j$ - before the mood sign, while the $2^{\text {nd }} \mathrm{p}$. du. has in the plural forms of the subject the plural form - $m$ before the aspect affix even if it has its normal $-b$ - in the ending. The $2^{\text {nd }} \mathrm{p}$. pl. is regular in having only $-m$ - in both positions. Sometimes, however, the shorter, more regular, form with only the object affix inserted before the aspect affix is also found side by side with the longer form. This is even normal for the $2^{\text {nd }}$ p.s. obj. aff. in the future, the $2^{\text {nd }} \mathrm{p}$. du. and $\mathrm{pl}$. being entirely similar to each other $(-m--m b e)$.

Otherwise the forms of the object affixes are the same as those in primary forms, but in the $1^{\text {st }}$ p. du. subject of the future and the adhortative the $3^{\text {rd }}$ p. object affixes are -nan- (or, through assimilation, -nam-) for the singular, and -mim- (or, through assimilation, -min-) for the dual and plural, while the $2^{\text {nd }}$ p. du., pl. object affix is -mam-.

The vowels are even more unstable than they are in primary forms. Being non-distinctive, except for the $3^{\text {rd }}$ p. du., pl., their type is more or less free, but influenced by environment, viz. the vowels of neighbouring syllables and/or the position of the stress. As in primary forms, the vowels may precede or follow the consonant, or, in some cases already referred to, stand between the doubled consonants. Examples: how-na-bo-ke, but by preference how-no-bo-ke, "he slew (something) for him" or "he slew him"; ho-no-bo-be, but also ho-nə-bo-be, "you two will slay (something for) him" (future); but always hoj-no-bo, "kill thou (something for) him!" (because of the stress on -no-); ha-nambom, "we two must kill (something for) him"; and regularly hojboja$n a-l e$, "I use to kill (something) for him every time" (iterative), and

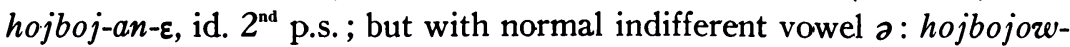
$n a$, id. $3^{\text {rd }}$ p.s.; etc.

The "actual" forms of the $1^{\text {st }}$ p. du. and pl. subject affixes show the $-a n$ - and -an-allomorphs when taking the $3^{\text {rd }}$ p.s., du. and pl. object affixes, but the -a- and $-a$ - plus juncture consonant $j$ when taking the $2^{\text {nd }}$ p.s., du. and pl. object affixes. The -an- and -an- forms may, but need not, assimilate to the $m$ of the $3^{\text {rd }}$ p. du., pl. object affix $-m i$ in the same manner as in primary forms (cf. III. 4. 7).

Examples: habrw-do-ko-ke, "he has beaten me" (aor. with asp. aff.

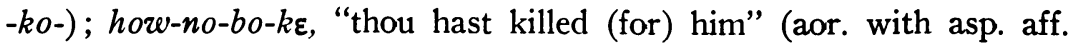
-bo-); (bana) nakaw-na-ma-ke, (a thought) came to dwell on him"

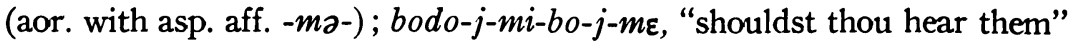
(condit. with -bo-); bodo-naj-mo-bo-n-de, "they will hear us" (future); $h a-n a m-b o-n d e$, "we two shall slay (for) him" (for *-nan-); haba-min- 
$k o-m$, "let us two beat them" (for *-mim- before asp. aff. -ko-); habaw-ko-k-a-wa-le, "I have hit thee" (aor. with -ko-); habaw-ko-k$a j-d e$, "he has hit thee"; habaj-arv-ko-k-aj-de, "we two (but also "they two") have hit thee" (with $2^{\text {nd }}$ p.s. obj. aff. - $\varkappa^{\prime}$ - before asp. aff. -ko- but allomorph -j-before mood aff. $-d e$ ); hab-aj-an-ko-ka-be, "we (pl.) (but also "they-pl.") have hit you two" (with $-m->-n-[\dot{\mathrm{n}}]$ before asp. aff. $-k o-$, and $-b$ - before mood ending: *-b-be $>-b e$ ); but habo-ko-k-a-ba-le, "I have hit you two" (with only -b- before mood ending); and hab-ajan-ko-k-am-be, "we (pl.) (but also "they-pl.") have hit you (pl.)" (with $-m$ - before both asp. aff. and mood ending; $-m->-n-[\dot{\mathrm{n}}]$ before $-k-)$; but also beside it the shorter, more regular, form with $-m$ - only once, before the aspect affix: $h a b-a j$-an-ko-k-e, "id.".

\section{4. 9. Composite verbal forms.}

Composite verbal forms, i.e., verbal forms composed of two differently inflected roots, the first of which indicates a movement (cf. III. 4), are found in various combinations. These are :

(1) both verbs are in the present;

(2) both verbs are in the habitualis, the second verb being either a primary or a secondary form ;

(3) the first verb is in the imperfect and the second in the aorist, this second verb being either primary or secondary;

(4) the first verb is in the aorist and the second in the present;

(5) the first verb is in the aorist and the second in the imperfect;

(6) the first verb is in the aorist and the second in the aorist of secondary form with directive aspect affix;

(7) both verbs are in the future, the second being either a primary or a secondary form;

(8) the first verb is in the adhortative and the second either in simple root-form (with only the $1^{\text {st }}$ p.s., du., pl. extended with the usual $-m$ ), or in secondary form.

Structurally two principal categories can be distinguished in these combinations :

(I) the first verb is in an imperfective or undeterminate form, followed by the second verb in a perfective or determinate form, except the secondary habitualis or iterative of type (2), which, though determinate, follows category (II);

(II) all other combinations, with the exception of combination type (7) (both constituents in the future), which, although the primary future is more or less indifferent to aspect, always follows category (I), 
and combination type (8) (adhortative) which also follows category (I), but with some peculiarities of its own, particularly if the second constituent is a secondary form.

In other words : in category (I) belong only the types (3), (7) and (8), in category (II) all the other types.

The characteristic difference in structure between the two categories is the following:

In category (II) the $2^{\text {nd }}$ constituent of the compound is fully inflected according to mood, tense and person for the subject concerned as primary or secondary form, as the case may be, while the only flexional affixes occurring in the $1^{\text {st }}$ constituent are those for tense and person for the subject, these latter being the "actual" forms of III. 4. 5, with the following exceptions: In type (4), (5) and (6) the $2^{\text {nd }}$ p.s. has been reduced to - -2 -, and the $3^{\text {rd }}$ p.s. may have either - - - (a morphophonemic variant of zero) or $-w-(-a w-)$; in type (1) the $3^{\text {rd }}$ p.s. has only -w-; and in type (2) the only flexional affix appearing in the first verb is throughout the $-j$ - which is characteristic of the habitualis.

In category (I) the $2^{\text {nd }}$ constituent of the compound has exactly the same flexional affixes as those following the aspect affix in non-composite secondary forms of the corresponding tenses and moods (see III. 4. 6). This means that (a) if the second constituent of the compound is in the aorist (type 3), the singular persons are inflected fully in the regular manner $(-k-a-l e,-k-\varepsilon,-k-e)$, but the dual and plural persons all have the one characteristic form in $-k e$ similar to that of the $3^{\text {rd }}$ p.s.; that (b) if the $2^{\text {nd }}$ constituent is in the future (type 7 ), only the $2^{\text {nd }} \mathrm{p}$. du. and $\mathrm{pl}$. have the regular endings $(-b e,-m b e)$ but all the other persons have the constant form in $-n-d e$ similar to the $3^{\text {rd }}$ p.s. ( $n$ for the future and $-d e$ for the indicative); and that (c) if the compound is in the adhortative (type 8 ), an additional $-m$ follows, in the $1^{\text {st }}$ p.s., du., pl., the second (root-form) constituent. If, however, the $2^{\text {nd }}$ constituent is a secondary form, the $-m$ follows the aspect affix with optional pleonastic addition after the $2^{\text {nd }}$ constituent, whereas then a similar repetition of the person affix of the first constituent is found in the $2^{\text {nd }}$ and $3^{\text {rd }}$ p.s.

The flexional elements in the first constituent of such compounds of category (I) also are in accordance with those which, in the corresponding tenses and moods of non-composite secondary forms, follow the root and precede the aspect affix; with the following exceptions: In type (3) the $1^{\text {st }}$ p.d., pl. have the regular -an- and -an-forms respectively, in conformity with the normal "actual" flexion, as against the forms -anda- and -anda- which we have found in the non-composite 
secondary aorist (see III. 4.6). In the adhortative (type 8) the $3^{\text {rd }}$ p.s. has -an- like the future instead of the normal -w-.

There is thus a strong resemblance between the last-mentioned compounds and the corresponding non-composite secondary forms. The differences are only few, as we have seen. Also a similar morphophonemic rule, as valid for the juncture between an aspect affix beginning with a vowel and a preceding flexional element ending in a vowel in secondary forms (cf. III.4.4), applies to the composite forms: if the second constituent of the compound begins with a vowel and the preceding flexional element of the first constituent ends in a vowel, the two vowels are not contracted or assimilated but linked by $-j-$, e.g., $m a-j-a n \partial-n-k o-n-d e$, "we two shall come-eat" (1" p.du. fut. of ma-, "come", plus ana- with asp. aff. -ko-, "eat"; type 7). But we have also seen (cf. note 10 supra), that there are several good structural objections to regarding these compounds and the non-composite secondary forms as similar formations, at least synchronically; historically, of course, they may well be of similar origin.

Examples: (type 1) $a-j-k o-j-\varepsilon$, "thou goest-doest" (roots a-, "go" + $k o-$, "do, act"); a-j-ko-j-de, id. $3^{\text {rd }}$ p. du. ; an- $k$-an-de, id. $1^{\text {st }}$ p. pl. (for

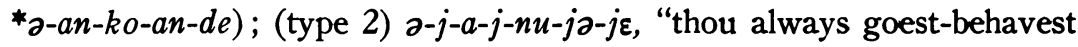
thyself" (roots $a-+a$-, "take up, carry", with reflex. aff. -nu-, "behave oneself"; and with habit. -ja-); $\partial-j-n u w a-j-b o-j o-l e$, or abbreviated, $e-j-$ nuw-bo-jo-le, "he always goes-sits (rests)" (roots a- + nuwa-, "rest" + asp. aff. -bo- and habit. -ja-); (type 3) $\partial-w-f a d \partial-k e$, "he was going-died (i.e., "in going he died"; roots $a-+$ hada-, "die"); a-j-sadake, "they two were going-died"; aj-sadəke, id. $3^{\text {rd }}$ p. pl. (for *ə-aj-hədəke); $o-w-d u w(a)-k-a-l e$, "I was descending-fell" (roots o-, "descend" + duwə-, "fall"); o-n-duw(a)-ke, id. $1^{\text {st }}$ p. du. (for *o-an-duwa-ke); $a n-d u w(\partial)-k e$, id. $1^{\text {*t }}$ p. pl. (for *o-an-duwake), but also "we went-fell" (for *a-an-duwa-ke with root $\partial$ - as first constituent); ma-w-wale-w$b o-k \varepsilon$, "thou camest-becamest alive; camest back to life"; a-w-nunde$w-b o-k-a-l e$, "I went-disappeared" (both with asp. aff. -bo-); (type 4) $a-k-a-k-a-l e$, "I went-do", i.e., "I went (and) do, I went (to) do" (roots o- $+k o-$, "do, act"); $\partial-k-\partial-k o-j-\varepsilon$, id. $2^{\text {nd }}$ p.s.; $\partial-k-a n-k-a n-d e$, id. $1^{\text {tt }}$ p. pl. (for *-ko-an-de); (type 5) a-k-aj-ko-w-aj-de, "they (pl.) went-have been doing" (for *-ko-wo-aj-de); ${ }^{*}-k-\partial-k o-w o-j-\varepsilon$, id. $2^{\text {nd }}$ p.s.; (type 6) $\partial-k-a-n \partial k \partial-\imath-\partial-k-a-l e$, "I went-started living, dwelling on", (first constit. $\partial-$, second constit. naka- with asp. aff. -ə-); ma-k-ə-nəkə-w$m ə-k-\varepsilon$, "thou camest-startedst staying hither, here" (first constit. mə-, second constit. naka- with asp. aff. -ma-); (type 7) a-da-hada-n-de, 
"I shall go-shall die"; $a-w-f a d \partial-n-d e$, id. $2^{\text {nd }}$ p.s.; $a-n-s \partial d \partial-n-d e$, id. $3^{\text {rd }}$ p.s. ; a-hada-be, id. $2^{\text {nd }}$ p. du.; a-ma-hada-n-de, id. $1^{\text {tt }}$ p. pl.; a-nsada-m-be, id. $2^{\text {nd }}$ p. pl. (for *a-m-hada-); a-naj-sada-n-de, id. $3^{\text {rd }}$ p. pl.; $m-a-j-a n a-n-k o-n-d e$, "we two shall-come-shall eat" (for *ma-a-ana-); (type 8) a-da-hada-m, "let me (I must) go-die" (adhort.); a-j-sada, id. $2^{\text {nd }}$ p.s. ; $a-h \partial d \partial-m$, id. $1^{\text {st }}$ p. du. ; etc.

\section{4. 10. Indication of the personal object in composite forms.}

If the composite form takes a personal object affix, it may have various positions in the structure according to whether the form is one of category (I) or category (II), and, in the former case, whether the second constituent of the compound is a primary or a secondary form. (a) If the compound is one of category (I), the object affix is treated in the same manner as it is in non-composite secondary forms, as if the first constituent were the verbal root and the second constituent the aspect affix (cf. III. 4. 8).

(b) If, however, the second constituent of such a category (I) compound is a secondary form, the object affix may be placed either as described in (a) supra - and this by preference -, or both as in (a) and again in the second constituent at the same time, which latter is then fully inflected as a non-composite secondary form with an object affix. The object affix thus may occur twice in the compound.

(c) If the composite form is one of category (II), the object affix is placed in the second constituent according to the rules of the corresponding non-composite forms, although sometimes here too the double indication is found - incorrectly, as one of my informants said - if the second constituent is a secondary form.

Examples: (type a) a-w-na-wa-k-a-le, "I went-told hum" (with $3^{\text {rd }}$ p.s. obj. aff. -na-; cf. for the position, ho-w-no-bo-k-a-le, "I killed (something for) him", sec. form with asp. aff. -bo-); a-w-wa-k-a-wa-le, "I went told thee" (with $2^{\text {nd }}$ p.s. obj. aff. -wa-; cf., for position, $k o-w-b o-$ $k$-a-wa-le, "I did to thee", sec. form with -bo-); a-da-n-wa-n-de, "I shall go-shall tell him" (cf. ho-da-m-bo-n-de, "I shall kill (something for) him", sec. form with -bo-); a-nən-wa-n-de, "we two shall go-shall tell him" (cf. $h-a-n \partial m-b o-n-d e)$; a-də-zəa-be, "you two will go-will tell me" (cf. ho-da-bo-be); a-naj-mi-wa-n-de, "they (pl.) will go-will tell them"; (type b) $\partial-w-n \partial-k \varepsilon-w-f i-k-\varepsilon$, "thou wert going-threwest it away" (cf. type a supra, but with $2^{\text {nd }}$ constit. in sec. form, while obj. aff. is still

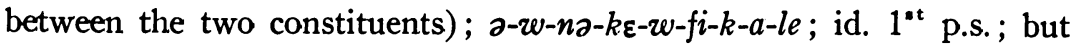

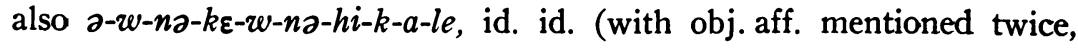


between the two constituents and in the second constituent, fully inflected as secondary form); $\boldsymbol{\partial}-d \partial-n-k \varepsilon-n-s i-n-d e$, "I shall go-shall throw it away" (with obj. aff. between the two constituents); a-ma-n-

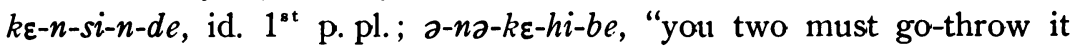
away" (adhort. with obj. aff. still between the two constituents); $a-n$ -

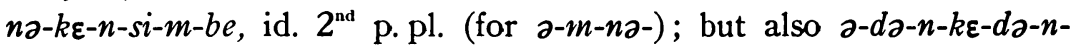
si-n-de = adankEnsinde above, but with obj. aff. mentioned twice, once between the two constituents and once in the second constituent, fully

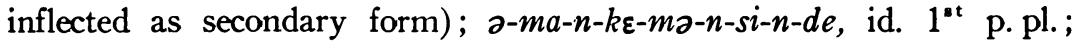
$a-n \partial-k \varepsilon-n \partial-h i-b e=a-n \partial-k \varepsilon-h i-b e$ above, but with similar double struc-

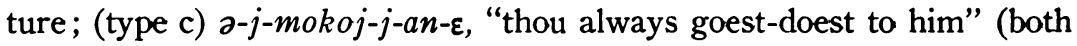
constituents in habitualis with obj. aff. in ending as regular); ma-ka(w-)moko-wo-w-na, "he came-has been making for him" (1 $1^{\text {tt }}$ constit. in aorist and $2^{\text {nd }}$ in imperf., with obj. aff. in ending as regular); $m ə-k-$ aj-nakə-j-nə-ma-ke, "they two came-settled in it up to now" ( $1^{\text {"t }}$ verb in primary and $2^{\text {nd }}$ verb in secondary aorist with directive asp. aff. -mo-, and obj. aff. in $2^{\text {nd }}$ verb as regular); $a-j-m o k o-j-b o-j-a n-\varepsilon$, "thou always goest-doest (something) to him" (cf. ajmokojjane above, but with $2^{\text {nd }}$ habitualis in secondary form with $-b o-$, and with obj aff. in ending as regular); $a-j-a-j-n u-j-a n-\varepsilon$, "thou always goest-behavest thyself towards him" (roots $\partial$ - and $a$-, "take up, carry", but $2^{\text {nd }}$ verb in secondary form with reflexive aff. $-n u$-, and with obj. aff. in ending as regular); etc.

\section{4. 11. The gerund.}

By repetition of root forms is formed a verbal noun or gerund. Structurally there are two types which are distinguished by (1) a dissyllabic or polysyllabic root, ending in -a preceded by one of the consonants admitted as finals, and (2) all other roots. The former tending, as we have seen (II. 4. 1 and III. 4. 1), to treat this consonant as root-final, it repeats the root in this form, with the consonant as final, e.g., hon-som (for *hom-hom < *hon-hon), "burning", from honə-, "burn, grill, roast"; am-am (for *an-an), "eating", from anə-, "eat" (cf. the composite word a'hamam, "food", lit. "things (for) eating"); dow-dow, "taking, receiving", from dowa-, "take"; etc. The other type adds $-j$ - to the root as in certain other flexional forms (see i.a. III. 4. 2-4), e.g. $-j-j-\partial-j$, "going"; from $a-$, "go"; $o-j-o-j$, "descending", from $o-$-, "descend"; $b \varepsilon-j-b \varepsilon-j$, "seeking", from $b \varepsilon-$, "seek"; $h e-j-$ $s e-j$, "hanging", from he-, "hang"; etc.

The gerund can also be formed from secondary forms, in which case 
the repetition is omitted, and the aspect affix takes the place of the second constituent of the repetition, e.g., $a-j-d i$, "going up" (with directive asp. aff. $-d i$-) ; $o-j-b o$, "collapsing, falling down" (from $o-$, "descend", with asp. aff. -bo-); $d e-j-k o$, "penetrating, driving into" (as of tree-roots); huw-bo, "feeling" (from huwo- and asp. aff. -bo-); etc.

Similarly the gerund of roots indicating a movement may as first constituent enter into composition with other verbal roots as second constituent, e.g., a-j-sabə, "going-throw"; mə-j-sabə, coming-throw"; i.e., "throwing thither" and "throwing hither" respectively, from habo-, "throw, cast, strike".

This gerund may also combine with another flexional form of the same verb to intensify its meaning. This construction, though more or less a borderline case, is to be regarded as composite and flexional for the reasons set forth in III. 2.2, last para. Also it shows a peculiarity which is also found in other composite flexional verb forms, viz. the juncture consonant $-j$ - between a final vowel of the $1^{\text {tt }}$ and an initial vowel of the $2^{\text {nd }}$ constituent ; e.g., $d e-j-k o$ - de-w-no-ko-ke, "penetrating, it penetrated into it" (gerund of $d e-$ with asp. aff. $-k o-$ plus $3^{\text {rd }}$ p.s. secondary aorist with $-k o-$, and with obj. aff. $3^{\text {rd }}$ p.s. $\left.-n o-\right)$; but $o-j-b o$ $-j-o-z-b o-k e$, "collapsing it collapsed" (gerund of $o-$, "descend, fall", with asp. aff. -bo- plus $3^{\text {rd }}$ p.s. secondary aorist with -bo-; the two constituents linked by $-j$ - between the final vowel of the first and the initial vowel of the second); etc. 


\section{PARADIGMATIC LISTS OF VERB FORMS.11}

\section{1. Primary Verb.}

Model : root ma-, "come".

IV. 1. 1. Indicative.

\begin{tabular}{|c|c|c|c|c|c|}
\hline Person & Present & Habitualis & Imperfect & Aorist & Future \\
\hline $1^{\text {tt }} \mathrm{sg}$. & male & məjjale & məwale & məkale & mədəle \\
\hline $2^{\text {nd }} \mathrm{sg}$. & məjع & məjјəjє & 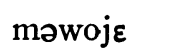 & məkع & məle \\
\hline $3^{\text {rd }} \mathrm{sg}$. & məle & məjjəle & məwole & məke & mənde \\
\hline let du. & mande & məjjənde & məwonde & məkənde & male \\
\hline $2^{\text {nd }} \mathrm{du}$. & məwbe & məjjəwbe & məwowbe & məkəwbe & mabe \\
\hline $3^{\text {rd }} \mathrm{du}$. & məjde & məjjəjde & məwojde & məkəjde & mənəjde \\
\hline $1^{\text {st }} \mathrm{pl}$. & mande & məjjande & məwande & məkande & məmale \\
\hline $2^{\text {nd }} \mathrm{pl}$. & mawbe & məjjav & məwawbe & məkawbe & mbe \\
\hline $3^{\text {rd }} \mathrm{pl}$. & majde & məjjajde & məwajde & məkajde & mənajde \\
\hline
\end{tabular}

IV. 1. 2. Adhortative.

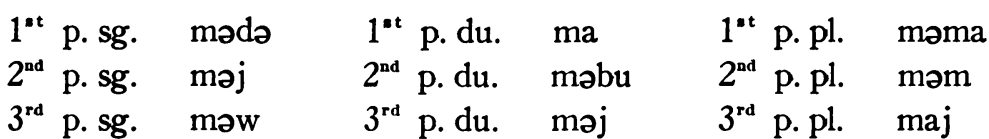

\section{1. 3. Conditional.}

$1^{\text {st }}$ p. sg. mole $2^{\text {nd }}$ p. sg. məjme $3^{\text {rd }}$ p. sg. mowbe (dual and plural supplied by corresponding persons of indicative, present)

\section{1. 4. Negative.}

all persons and tenses : əməj (not further inflected)

\section{1. 5. Vetative.}

$2^{\text {nd }}$ p. sg. əməj-j $\varepsilon$

$$
2^{\text {nd }} \text { p. du., pl. əməm-me }
$$

(not further inflected)

11 These paradigms are complete, not in absolute numbers of all theoretically possible forms, but in the sense of models after which all possible forms can be reconstructed with the aid of the grammatical description in the foregoing pages. 
IV. 2. Primary Verb with object affix.

Model : root wa- + obj. aff., "say to, tell".

IV. 2. 1. Indicative with $2^{\text {nd }}$ p.s. obj. aff. (-w- $\sim-j-$-) as model.

Person Present Imperfect Aorist Future

$1^{\text {"t }}$ sg. wawale uwawale 12 ukawale wədəjde

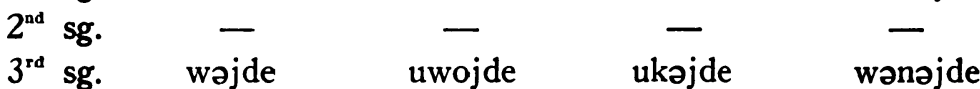

sg. Wojde ukəjde

$1^{\text {ot }}$ du. wəjəjde uwojəjde ukəjəjde wajəjde

$2^{\text {nd }} \mathrm{du} . \quad-\quad$ - $\quad$ - $\quad-$

$3^{\text {rd }}$ du. wəjəjde uwojəjde ukəjəjde wənəjəjde

$1^{\text {st }} \mathrm{pl}$ wajəjde uwajəjde ukajəjde wəmajde

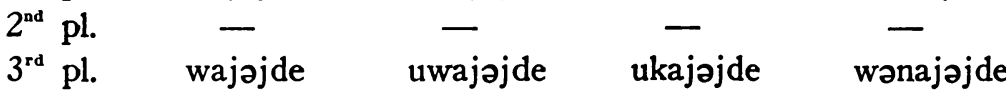

IV. 2. 2. Indicative with $3^{\text {rd }}$ p.s. obj. aff. (-n-) as model.

\begin{tabular}{|c|c|c|c|c|}
\hline Person & Present & Imperfect & Aorist & Future \\
\hline $1^{\text {at }} \mathrm{sg}$. & wanale & uwanale & ukanale & wədənde \\
\hline $2^{\text {nd }} \mathrm{sg}$. & wanc & uwane & ukane & wəwnəle \\
\hline $3^{\text {rd }} \mathrm{sg}$. & wəwnə & uwownə & ukəwnə & wənənde \\
\hline $1^{\text {tt }} \mathrm{du}$. & wənənde & uwonənde & ukənənde & wanənde \\
\hline $2^{\text {nd }} \mathrm{du}$. & wəwnə & uwownə & ukəwnəle & wənəle \\
\hline $3^{\text {rd }} \mathrm{du}$. & wəjnə & uwojnə & ukəjnəle & wənəjnəle \\
\hline $1^{\text {tt }} \mathrm{pl}$. & wanənde & uwanənde & ukanənde & wəmande \\
\hline $2^{\text {nd }} \mathrm{pl}$. & wawnə & uwawnə & ukawnəle & wənnəle \\
\hline $3^{\text {rd }} \mathrm{pl}$. & wajnə & uwajnə & ukajnəle & wənajnəle \\
\hline
\end{tabular}

IV. 2. 3. Indicative with $3^{\text {rd }}$ p. du., pl. obj. aff. (-mi-) as model.

Person Present Imperfect Aorist

$1^{\text {st }} \mathrm{sg}$. wamele uwamele ${ }^{12}$ ukamele wədəmile

$2^{\text {nd }} \mathrm{sg}$. wame uwame ukame wowmile

$3^{\text {rd }} \mathrm{sg}$. wəwmi uwowmi ukəwmi wənəmile

$1^{\text {tt }} \mathrm{du}$. wəmmile 13 uwonəmile ${ }^{14}$ ukəmmile 13 wamile

$2^{\text {nd }} \mathrm{du}$. wəwmi uwowmi ukəwmi wəmile

$3^{\text {rd }}$ du. wəjmi uwojmi ukəjmi wəojmile

$12 u$ - in all these forms for -wo-.

13 Or -nomile instead of -mmile; cf. III. 4.7.

14 Or -mmile instead of -nomile; cf. III.4.7. 
$1^{\text {at }}$ pl. wammile 13 uwanəmile 14 ukammile 13 wəmamile

$2^{\text {nd }} \mathrm{pl}$. wawmi uwawmi ukawmi wommile

$3^{\text {rd }} \mathrm{pl}$ wajmi uwajmi ukajmi wəujmile

IV. 2. 4. Adhortative with $2^{\text {nd }}$ p.s. obj. aff. (-w.) as model.

$1^{\text {st }}$ p. sg. udəwəm $121^{\text {st }}$ p. du. wawəm $1^{\text {st }}$ p. pl. umawəm

$2^{\text {nd }}$ p.sg. - $\quad 2^{\text {nd }}$ p.du. $\quad-\quad 2^{\text {nd }}$ p. pl. -

$3^{\text {rd }}$ p.sg. wəwwə, $3^{\text {rd }}$ p. du. wəjəw $3^{\text {rd }}$ p. pl. wajəw uwวw

IV. 2. 5. Adhortative with $3^{\text {rd }}$ p.s. obj. aff. (-n-) as model.

$1^{\text {*t }}$ p. sg. udənəm, $1^{\text {st }}$ p. du. wanəm $1^{\text {st }}$ p. pl. umanəm, udəm umam

$2^{\text {nd }}$ p.sg. wəjnə $2^{\text {nd }}$ p.du. wənə $2^{\text {nd }}$ p. pl. wənnə

$3^{\text {rd }}$ p.sg. wəwnə $3^{\text {rd }}$ p. du. wəjnə $3^{\text {rd }}$ p. pl. wajnə

IV. 2. 6. Conditional with obj. aff. $2^{\text {nd }}$ and $3^{\text {rd }}$ p.s. as models.
(a) $2^{\text {nd }}$ p.s. $(-\mathrm{w}-\sim-\mathrm{j}-)$
(b) $3^{\text {rd }}$ p.s. (-n-)
$1^{\text {tt }}$ p. sg. wəjəjde
$1^{\text {tt }}$ p. sg. wənəle
$2^{\text {nd }}$ p. sg.

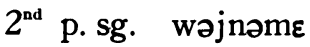
$3^{\text {rd }}$ p. sg. uwowbe
$3^{\text {rd }}$ p. sg. wawnobe

IV. 2. 7. Vetative with obj. aff. $1^{\text {tt }}$ and $3^{\text {rd }}$ p. sg. and du., pl. as models.

(a) $1^{\text {st }}$ p.s. (-d-)

$2^{\text {nd }}$ p. sg.

$2^{\text {nd }}$ p. du., pl.

(c) $3^{\text {rd }}$ p.s. (-n-)

$2^{\text {nd }}$ p. sg.

$2^{\text {nd }}$ p. du., pl. วwəjdəm-m $\varepsilon$

วwəndəm-me

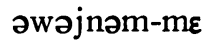

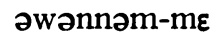

(b) $1^{\text {st }}$ p.du., pl. (-m-)

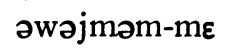

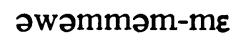

(d) $3^{\text {rd }}$ p.du., pl. (-mi-)

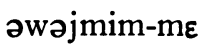

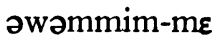

\section{3. Secondary Verb.}

Model : root ho-, "slay", with aspect affix -bo-.

\section{3. 1. Indicative.}

$\begin{array}{llll}\text { Person } & \begin{array}{l}\text { Habitualis } \\ \text { (Iterative) }\end{array} & \text { Aorist } & \text { Future } \\ 1^{\text {t }} \text { sg. } & \text { hojbojale } & \text { howbokale } & \text { hodəbonde } \\ 2^{\text {nd }} \text { sg. } & \text { hojbojoje } & \text { howboke } & \text { howbonde } \\ 3^{\text {rd }} \text { sg. } & \text { hojbojole } & \text { howboke } & \text { hombonde }\end{array}$




\begin{tabular}{|c|c|c|c|}
\hline $\begin{array}{l}1^{\text {st }} d u . \\
2^{\text {nd }} d u . \\
3^{\text {rd }} d u .\end{array}$ & $\begin{array}{l}\text { hojbojonde } \\
\text { hojbojowbe } \\
\text { hojbojojde }\end{array}$ & $\begin{array}{l}\text { hondəboke } \\
\text { howboke } \\
\text { hojboke, } \\
\text { hojbokəjde }\end{array}$ & $\begin{array}{l}\text { habonde } \\
\text { hobobe } \\
\text { honəjbonde }\end{array}$ \\
\hline $1^{\text {st }} \mathrm{pl}$. & hojbojande & handəboke & homabonde \\
\hline $2^{\text {nd }} \mathrm{pl}$ & hojbojawbe & hawboke & hombombe \\
\hline $3^{\text {rd }} \mathrm{pl}$. & hojbojajde & $\begin{array}{l}\text { hajboke, } \\
\text { hajbokajde }\end{array}$ & honajbonde \\
\hline
\end{tabular}

IV. 3. 2. Adhortative.

$1^{\text {tt }}$ p. sg. hodobom $1^{\text {st }}$ p.du. habom $1^{\text {st }}$ p. pl. homabom

$2^{\text {nd }}$ p. sg. hojbo $\quad 2^{\text {nd }}$ p. du. hobo $\quad 2^{\text {nd }}$ p. pl. hombo

$3^{\text {rd }}$ p. sg. howbo $3^{\text {rd }}$ p. du. hojbo $3^{\text {rd }}$ p. pl. hajbo

IV. 3.3. Conditional.

$1^{\text {tt }}$ p.sg. hojbole $1^{\text {tt }}$ p. du. hondəbobe $1^{\text {tt }}$ p. pl. handəbobe

$2^{\text {nd }}$ p. sg. hojbojme $2^{\text {nd }}$ p. du. howbobe $2^{\text {nd }}$ p. pl. hawbobe

$3^{\text {rd }}$ p.sg. howbobe $3^{\text {rd }}$ p.du. hojbobe $3^{\text {rd }}$ p. pl. hajbobe

IV. 3. 4. Negative.

all persons and tenses: əhojboj (not further inflected)

IV. 3. 5. Vetative.

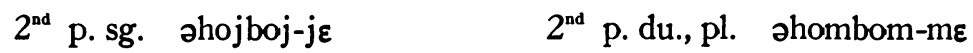

(not further inflected)

IV. 4. Secondary Verb with object affix.

Model : root moko-, "make, do" + asp. aff. -bo-.

IV. 4. 1. Indicative: Habitualis (Iterative) with $3^{\text {rd }}$ p.s. obj. aff. as model.

$1^{\text {tt }}$ p.sg. mokojbojanale $1^{\text {st }}$ p. du. mokojbojonənde

$2^{\text {nd }}$ p.sg. mokojbojane $2^{\text {nd }}$ p. du. mokojbojowno

$3^{\text {rd }}$ p. sg. mokojbojownə $3^{\text {rd }}$ p. du. mokojbojojnə

$1^{\text {st }}$ p. pl. mokojbojanənde

$2^{\text {nd }}$ p. pl. mokojbojawno

$3^{\text {rd }}$ p. pl. mokojbojajnə 
IV. 4. 2. Indicative with $1^{\text {st }}$ p. sg. obj. aff. (-d.) as model.

Person Aorist Future

$1^{\text {st }} \mathrm{sg}$.

$2^{\text {nd }} \mathrm{sg}$.

$$
\text { Aorist }
$$

mokowdoboke

$3^{\text {rd }} \mathrm{sg}$. mokowdoboke

mokowdobonde

$1^{\text {st }} \mathrm{du}$.

$2^{\text {nd }} \mathrm{du}$.

mokowdoboke

mokondəbonde

$3^{\text {rd }} \mathrm{du}$.

mokojdoboke

$1^{\text {st }} \mathrm{pl}$.

$2^{\text {nd }} \mathrm{pl}$.

$3^{\text {rd }} \mathrm{pl}$.

mokawdoboke

mokajdoboke

IV. 4. 3. Indicative with $2^{\text {nd }}$ p.s. obj. aff. $(\cdot-w \cdot \sim \cdot j \cdot)$ as model.

\begin{tabular}{|c|c|c|}
\hline Person & Aorist & Future \\
\hline $1^{\text {st }} \mathrm{sg}$. & mokowbokawale & mokodəwbonde \\
\hline $2^{\text {nd }} \mathrm{sg}$ & - & - \\
\hline $3^{\text {rd }} \mathrm{sg}$. & mokowbokəjde & mokonəwbonde \\
\hline $1^{\text {st }} \mathrm{du}$. & mokojəwbokəjde 15 & mokawobonde \\
\hline $2^{\text {nd }} \mathrm{du}$ & - & - \\
\hline $3^{\text {rd }} \mathrm{du}$. & mokojəwbokəjde 15 & mokonəjowbonde \\
\hline $1^{\text {tet }} \mathrm{pl}$. & mokajəwbokəjde 15 & mokomawbonde \\
\hline $2^{\text {nd }} \mathrm{pl}$ & - & - \\
\hline $3^{\text {rd }} \mathrm{pl}$. & mokajəwbokəjde 15 & mokonajowbonde \\
\hline
\end{tabular}

IV. 4. 4. Indicative with $3^{\text {rd }}$ p.s. obj. aff. (-n-) as model.

\begin{tabular}{|c|c|c|}
\hline Person & Aorist & Future \\
\hline $\begin{array}{l}1^{\text {st }} \mathrm{sg} . \\
\text { etc. }\end{array}$ & $\begin{array}{l}\text { mokownobokale } \\
\text { etc. as } 1^{\text {st }} \text { p.s. obj. aff. } \\
\text { (IV. 4. 2) }\end{array}$ & $\begin{array}{l}\text { mokodəmbonde } \\
\text { etc. as } 1^{\text {st }} \text { p.s. obj. aff. } \\
\text { (IV. 4. 2) }\end{array}$ \\
\hline $\begin{array}{l}1^{\text {st }} \mathrm{du} . \\
\text { etc. }\end{array}$ & $\begin{array}{l}\text { mokonəmboke } \\
\text { etc. as } 1^{\text {st }} \text { p.s. obj. aff. } \\
\text { (IV. 4. 2) }\end{array}$ & $\begin{array}{l}\text { mokanəmbonde } \\
\text { etc. as } 1^{\text {tt }} \text { p.s. obj. aff. } \\
\text { (IV. 4. 2) }\end{array}$ \\
\hline $\begin{array}{l}1^{\text {et }} \mathrm{pl} . \\
\text { etc. }\end{array}$ & $\begin{array}{l}\text { mokanəmboke } \\
\text { etc. as } 1^{\text {at }} \text { p.s. obj. aff. } \\
\text { (IV. 4.2) }\end{array}$ & $\begin{array}{l}\text { mokomambonde } \\
\text { etc. as } 1^{\text {tt }} \text { p.s. obj. aff. } \\
\text { (IV. 4. 2) }\end{array}$ \\
\hline
\end{tabular}

15 Or -jəwboke instead of -jəwbokəjde; cf. III. 4. 8, type (3). 
IV. 4. 5. Indicative with $2^{\text {nd }}$ p. du. and pl. obj. aff. as models.

\begin{tabular}{|c|c|c|c|}
\hline Person & $\begin{array}{l}\text { Aorist } \\
\text { (with } 2^{\text {nd }} \text { p. du. obj.) }\end{array}$ & $\begin{array}{l}\text { Aorist } \\
\text { (with } 2^{\text {nd }} \text { p. pl. obj.) }\end{array}$ & Future \\
\hline $1^{\text {tt }} \mathrm{sg}$. & mokobokabale 16 & mokombokamale & mokodəmbombe \\
\hline $2^{\text {nd }} \mathrm{sg}$. & - & - & - \\
\hline $3^{\text {rd }} \mathrm{sg}$. & mokobokəbe & mokombokəmbe & mokonəmbombe \\
\hline $1^{\text {st }} \mathrm{du}$. & mokojəmbokəbe & mokojəmbokəmbe & mokaməmbombe \\
\hline $2^{\text {nd }} \mathrm{du}$ & - & - & - \\
\hline $3^{\text {rd }} \mathrm{du}$. & mokojəmbokəbe & mokojambokəmbe & mokonəjəmbombe \\
\hline $1^{\text {et }} \mathrm{pl}$ & mokajəmbokəbe & mokajəmbokəmbe & mokomambombe \\
\hline $2^{\text {nd }} \mathrm{pl}$. & - & - & - \\
\hline $3^{\text {rd }} \mathrm{pl}$. & mokajəmbokəbe & mokajəmbokəmbe & mokonajəmbombe \\
\hline
\end{tabular}

IV. 4. 6. Adhortative with obj. aff. $3^{\text {rd }}$ p.s. (-n-) as model.

$1^{\text {st }}$ p. sg. mokodəmbom $1^{\text {st }}$ p. du. mokanəmbom

$2^{\text {nd }}$ p. sg. mokojnobo $2^{\text {nd }}$ p. du. mokonobo

$3^{\text {rd }}$ p.sg. mokownobo $3^{\text {rd }}$ p. du. mokojnobo

$\begin{array}{lll}1^{\text {st }} & \text { p. pl. } & \text { mokomambom } \\ 2^{\text {nd }} & \text { p. pl. } & \text { mokonnobo } \\ 3^{\text {rd }} & \text { p. pl. } & \text { mokajnobo }\end{array}$

IV. 4. 7. Conditional with obj. aff. $3^{\text {rd }}$ p.s. (-n-) as model.

$1^{\text {st }}$ p.sg. mokojnobole $1^{\text {tt }}$ p. du. mokanəmbobe

$2^{\text {nd }}$ p. sg. mokojnobojme $2^{\text {nd }}$ p. du. mokonəbobe

$3^{\text {rd }}$ p. sg. mokownobobe $\quad 3^{\text {rd }}$ p. du. mokojnəbobe

$$
\begin{array}{ll}
1^{\text {st }} & \text { p. pl. mokomambobe } \\
2^{\text {nd }} & \text { p. pl. mokonnobobe } \\
3^{\text {rd }} & \text { p. pl. mokajnobobe }
\end{array}
$$

IV. 4. 8. Vetative with obj. aff. $1^{\text {ot }}$ p.s. (-d-) as model.

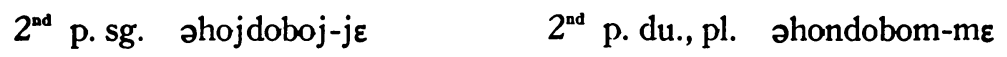

\section{5. Composite Verb, Category I.}

type $3 \mathrm{a}$ (imperfect + pri- type $3 \mathrm{~b}$ (imperfect + secondary aorist); model: mary aorist); model: roots roots mə-, "come" + nəkə-, "sit, stay" with ə-, "go" + ədə-, "see". asp. aff. -ko-.

16 For *moko-b-bokabale; cf. III. 4. 8, type (3). 
$1^{\text {tt }}$ p. sg. əwədəkale

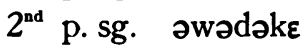

$3^{\text {rd }}$ p. sg. əwədəke

$1^{\text {st }}$ p. du. ənədəke

$2^{\text {nd }}$ p. du. əwədəke

$3^{\text {rd }}$ p. du. $ә$ jədəke

$1^{\text {t }}$ p. pl. anədəke

$2^{\text {nd }}$ p. pl. awədəke

$3^{\text {rd }}$ p. pl. ajədəke

type 7a (future + primary future) ; model: roots $\theta$-, "go" + hado-, "die".

$1^{\text {at }}$ p. sg. ədəhədənde

$2^{\text {nd }}$ p. sg. .wfədənde

$3^{\text {rd }}$ p. sg. ənsədənde

$1^{\text {tat }}$ p. du. ahədənde

$2^{\text {nd }}$ p. du. əhədəbe

$3^{\text {rd }}$ p. du. .nəjsədənde

$1^{\text {tt }}$ p. pl. amahədənde

$2^{\text {dn }}$ p. pl. ənsədəmbe

$3^{\text {rd }}$ p. pl. ənajsədənde

type 8a (adhort. + root-

form) ; model: roots $\theta_{-}$,

"go" + hado-, "die".

$1^{\text {st }}$ p.sg. ədəhədəm

$2^{\text {nd }}$ p. sg. əjsədə

$3^{\text {rd }}$ p. sg. ənsədə

$1^{\text {st }}$ p. du. ahədəm

$2^{\text {nd }}$ p. du. əhədə

$3^{\text {rd }}$ p. du. $ә$ jsədə

$1^{\text {*t }}$ p. pl. əmahədəm

$2^{\text {nd }}$ p. pl. ənsədə

$3^{\text {rd }}$ p. pl. ajsədə $1^{\text {tt }}$ p. sg. məwnəkəwkokale

$2^{\text {nd }}$ p. sg. məwnəkəwkoke

$3^{\text {rd }}$ p. sg. məwnəkəwkoke

$1^{\text {st }}$ p. du. mənnəkəwkoke

$2^{\text {nd }}$ p. du. məwnəkəwkoke

$3^{\text {rd }}$ p. du. məjnəkəwkoke

$1^{\text {tit }}$ p. pl. mannəkəwkoke

$2^{\text {nd }}$ p. pl. mawnəkəwkoke

$3^{\text {rd }}$ p. pl. majnəkəwkoke

type $7 \mathrm{~b}$ (future + secondary future); model: roots mo-, "come" + anə- with asp. aff. -ko-, "eat".

$1^{\text {ot }}$ p. sg. mədəjanənkonde $\mathbf{1 7}$

$2^{\text {nd }}$ p. sg. məwanənkonde

$3^{\text {rd }}$ p. sg. mənanənkonde

$1^{\text {st }}$ p. du. majanənkonde 17

$2^{\text {nd }}$ p. du. məjanəkobe 17

$3^{\text {rd }}$ p. du. mənəjanənkonde

$1^{\text {st }}$ p. pl. məmajanənkonde $\mathbf{1 7}$

$2^{\text {nd }}$ p. pl. məmanənkombe

$3^{\text {rd }}$ p. pl. mənajanənkonde

type $8 \mathrm{~b}$ (adhort. + secondary adhort.); model: roots mo-, "come" + an $\theta-$ with asp. aff. -hi-, "drink".

$1^{\text {st }}$ p. sg. mədəjanənsim, mədəjanəhim

$2^{\text {nd }}$ p. sg. məjanəjsi

$3^{\text {rd }}$ p. sg. mənanənsi

$1^{\text {st }}$ p. du. majanənsim, majanəhim

$2^{\text {nd }}$ p. du. məjanəhi

$3^{\text {rd }}$ p. du. məjanəjsi

$1^{\text {st }}$ p. pl. məmajanənsim, məmajanəhim

$2^{\text {nd }}$ p. pl. məmanənsim

$3^{\text {rd }}$ p. pl. majanəjsi

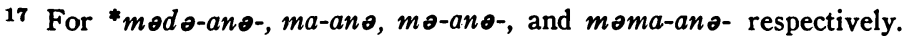




\section{5. 1. Composite Verb. Category II.}

type 1 (both verbs in present); model: roots o-, "go" + ko-, "do, act".

$1^{\text {tt }}$ p.sg. akale $1^{\text {tt }}$ p. du. onkonde $1^{\text {tt }}$ p. pl. ankande

$2^{\text {nd }}$ p. sg. əjkoje $\quad 2^{\text {nd }}$ p. du. əwkowbe $2^{\text {nd }}$ p. pl. awkawbe

$3^{\text {rd }}$ p.sg. əwkole $\quad 3^{\text {rd }}$ p. du. əjkojde $\quad 3^{\text {rd }}$ p. pl. ajkajde

type $2 \mathrm{a}$ (habitualis + primary habitualis); model as before.

$1^{\text {tt }}$ p. sg. əjkojjale

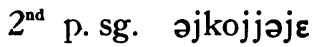

$3^{\text {rd }}$ p. sg. $ә$ jkojjəle

$1^{\text {tt }}$ p. du. əjkojjənde

$2^{\text {nd }}$ p. du. $\partial j k o j j ə w b e$

$3^{\text {rd }}$ p. du. əjkojjəjde

$1^{\text {tt }}$ p. pl. ajkojjande

$2^{\text {nd }}$ p. pl. əjkojjawbe

$3^{\text {rd }}$ p. pl. əjkojjajde type $2 \mathrm{~b}$ (habitualis + secondary habitualis); model: roots mo-, "come" + moko-, "do, work" with asp. aff. -bo-.

$1^{\text {tt }}$ p. sg. mojmokojbojale

$2^{\text {nd }}$ p. sg. məjmokojbojoje

$3^{\text {rd }}$ p. sg. məjmokojbojole

$1^{\text {st }}$ p. du. məjmokojbojonde

$2^{\text {nd }}$ p. du. məjmokojbojowbe

$3^{\text {rd }}$ p. du. majmokojbojojde

$1^{\text {st }}$ p. pl. majmokojbojande

$2^{\text {nd }}$ p. pl. məjmokojbojawbe

$3^{\text {rd }}$ p. pl. məjmokojbojajde

type 4 (aorist + present); model : roots o-, "go" + ko-, "do act".

$1^{\text {st }}$ p.sg. akakale $1^{\text {st }}$ p. du. akənkonde $1^{\text {st }}$ p. pl. akankande $2^{\text {nd }}$ p. sg. $2 k \partial k o j \varepsilon \quad 2^{\text {nd }}$ p. du. $2 k \partial w k o w b e 2^{\text {nd }}$ p. pl. $2 k a w k a w b e$ $3^{\text {rd }}$ p. sg. $2 k ə(w) k o l e ~ 3^{\text {rd }}$ p. du. əkəjkojde $\quad 3^{\text {rd }}$ p. pl. əkajkajde

type 5 (aorist + imperfect); model as before.

$1^{\text {tt }}$ p. sg. əkakowale

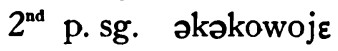

$3^{\text {rd }}$ p. sg. $\quad$ akə(w)kowole $1^{\text {st }}$ p. du. akankowonde

$2^{\text {nd }}$ p. du. akawkowowbe

$3^{\text {rd }}$ p. du. akəjkowojde

$1^{\text {tt }}$ p. pl. akankowande

$2^{\text {nd }}$ p. pl. akawkowawbe

$3^{\text {rd }}$ p. pl. akajkowajde

type 6 (aorist + secondary aorist with directive asp. aff.) ; model : mə-, "come" + noko-, "sit, stay, settle", with asp. aff. -mə-.

$1^{\text {tt }}$ p.sg. məkanəkəwməkale $1^{\text {st }}$ p. du. məkənnəkəndəməke

$2^{\text {nd }}$ p. sg. məkənəkəwməke $2^{\text {nd }}$ p. du. məkəwnəkəwməke

$3^{\text {rd }}$ p.sg. məkənəkəwməke $3^{\text {rd }}$ p. du. məkəjnəkəjməke

$1^{\text {st }}$ p. pl. məkannəkandəməke

$2^{\text {nd }}$ p. pl. məkawnəkawməke

$3^{\text {rd }}$ p. pl. məkajnəkajməke 


\section{6. Composite Verb with object affix. Category I.} Models : types 3 and 7

type $3 a$ (imperfect + primary aorist); model : roots o-, "go" + wo- with obj. aff. $3^{\text {rd }}$ p.s. $-n-=$ "say to him".

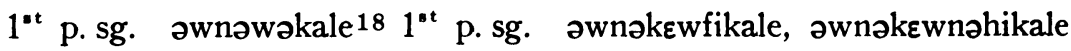
$2^{\text {nd }}$ p.sg. .

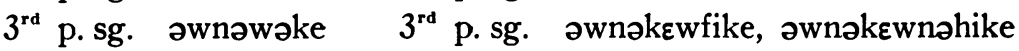

$1^{\text {st }}$ p.du. ənənwəke $1^{\text {st }}$ p. du. ənənkewfike, ənənkenənəhike, -kenənsike

$2^{\text {nd }}$ p. du. əwnəwəke $3^{\text {rd }}$ p. du. əjnəwəke

$1^{\text {:t }}$ p. pl. anənwake

$2^{\text {nd }}$ p. pl. awnəwəke

$3^{\text {rd }}$ p. pl. ajnəwəke type $3 \mathrm{~b}$ (imperfect + secondary aorist); model roots o-, "go" $+k \varepsilon$ - with asp. aff. -hi- and obj. aff. $3^{\text {rd }}$ p.s. $-n$ - $=$ "throw it away".

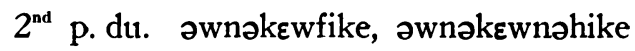

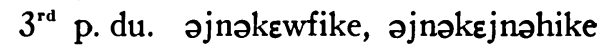

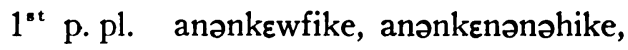
-kenənsike

$2^{\text {nd }}$ p. pl. awnəkewfike

$3^{\text {rd }}$ p. pl. ajnokewfike

type $7 \mathrm{a}$ (future + primary type $7 \mathrm{~b}$ (future + secondary future); model: as future); model as for $3 \mathrm{a}$. for $3 \mathrm{~b}$.

$1^{\text {tt }}$ p.sg. ədənwənde $1^{\text {tt }}$ p. sg. ədənkensinde, ədənk

$2^{\text {nd }}$ p. sg. əwnəwənde $2^{\text {nd }}$ p. sg. .

$3^{\text {rd }}$ p. sg. ənnəwənde $3^{\text {rd }}$ p. sg. ənənkensinde, ənənkenənsinde

$1^{\text {st }}$ p. du. anənwənde $1^{\text {st }}$ p. du. anənkensinde, anənkenənsinde

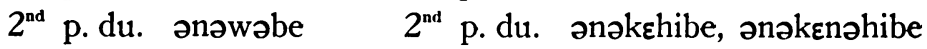

$3^{\text {rd }}$ p. du. ənəjnəwənde $3^{\text {rd }}$ p. du. ənəjnəkहnsinde, ənəjnəkह(nəj)nəhinde

$1^{\text {st }}$ p. pl. əmanwənde $1^{\text {st }}$ p. pl. əmankensinde, əmankemansinde

$2^{\text {nd }}$ p. pl. ənnəwəmbe $2^{\text {nd }}$ p. pl. ənnəkensimbe, ənnəkennəhimbe

$3^{\text {rd }}$ p. pl. ənajnəwənde $3^{\text {rd }}$ p. pl. ənajnəkensinde, ənajnəkg(naj)nəhinde

\section{6. 1. Composite Verb with object affix. Category II.}

Models : types $1,2 \mathrm{~b}$ and 5

18 With $2^{\text {nd }}$ p.s. object affix: ozerevarevale; cf. non- composite secondary form mokowbokawale in paradigm IV.4.3. 
type 1 (both verbs in present); model: roots $0-$, "go" + ko-, “do, act" with obj. aff. $3^{\text {rd }}$ p. sg. - $n-$.

$1^{\text {st }}$ p.sg. akanale $1^{\text {st }}$ p.du. ənkonənde $1^{\text {st }}$ p. pl. ankanənde

$2^{\text {nd }}$ p.sg. əjkane $2^{\text {nd }}$ p. du. əwkownə $2^{\text {nd }}$ p. pl. awkawnə

$3^{\text {rd }}$ p. sg. əwkownə $3^{\text {rd }}$ p. du. əjkojnə $3^{\text {rd }}$ p. pl. ajkajnə

type $2 \mathrm{~b}$ (habitualis + secondary habitualis); model as before, but with asp. off. -ko-.

$1^{\text {st }}$ p.sg. əjkojkojanale $1^{\text {st }}$ p. du. ajkojkojonənde

$2^{\text {nd }}$ p.sg. əjkojkojane $2^{\text {nd }}$ p. du. əjkojkojownə

$3^{\text {rd }}$ p. sg. əjkojkojownə $\quad 3^{\text {rd }}$ p. du. əjkojkojojnə

$$
\begin{array}{lll}
1^{\text {st }} & \text { p. pl. } & \text { əjkojkojanənde } \\
2^{\text {nd }} & \text { p. pl. } & \text { əjkojkojawnə } \\
3^{\text {rd }} & \text { p. pl. } & \text { əjkojkojajnə }
\end{array}
$$

type 5 (aorist + imperfect); model as for type 1.

$1^{\text {st }}$ p. sg. okakowanale

$1^{\text {st }}$ p. du. akənkowonənde

$2^{\text {nd }}$ p. sg. . $k$ okowane

$2^{\text {nd }}$ p. du. akəwkowownə

$3^{\text {rd }}$ p.sg. əkəkowownə

$3^{\text {rd }}$ p. du. əkəjkowojnə

$1^{\text {tt }}$ p. pl. əkankowanənde

$2^{\text {nd }}$ p. pl. əkawkowawnə

$3^{\text {rd }}$ p. pl. əkajkowajnə 


\section{SYNTAX.}

\section{V.1. General remarks.}

In the foregoing chapters certain subjects of a semi-syntactical nature have been mentioned because they were marginal features showing points which are reminiscent of both morphology and syntax, or because they were necessary for a good understanding of morphological phenomena. In the latter category belongs, for instance, the discussion in III. 4.4 on the aspectual value of tenses, which was necessary for understanding the nature of what $I$ have named the aspectual affixes. In the former belong discussions on borderline cases, such as those in III. 2.2 and III. 4. 11. Interpenetration of levels cannot always be avoided in a complicated language as Sentani. In this chapter on Syntax such features will be touched upon again, but only to the extent that is necessary. Thus the discussion on borderline cases will only be mentioned in passing, when giving examples of syntactic constructions concerned therein, but the question of aspect and tense, which was only briefly mentioned in III. 4. 4, will be gone into in much greater detail when giving examples of the distinctions between them, and their use in the sentence.

\section{2. Word, phrase and sentence.}

While the Sentani word, whose structure was dealt with in the chapters on phonology and morphology, is a minimum free form, the sentence is the maximum free form of an utterance which is a grammatical unit. It stands in absolute position and is not included in a longer grammatical form. The sentence contains one or more phrases, free forms in included position which in their turn consist of one or more words. An example of a sentence which is at the same time a phrase and a word, is, e.g., hadake, "he (has) died" ( $3^{\text {rd }}$ p.s. primary aorist of hədə-). An example of a two-word phrase which is not a sentence, is, e.g., ime kabam, "the (or a) big house". But this same form can, with or without a slight pause between the two words, also mean "the house is big", and then we have an example of a two-word phrase which is at once a sentence. A sentence which contains more 
than one phrase is, e.g., $k a^{\prime} j i$ kabam nahi'bi duwawoke, "the big canoe promptly sank", in which $k a^{\prime} j i$ kabam, "the big canoe", and nahi'bi duwawoke, "promptly sank", are both two-word phrases.

In the following sections we shall discuss our subject on the basis of the phrase only, in its occurrence both as or in a sentence and as a lesser free form.

\section{V.3. Structure of the phrase.}

Phrases of one word may consist of an inflected form, e.g., hadake, "he died", or a root word, e.g., ako!, "father, old man!"; maka?, "what?"; nə!, "yes!"; nawa, "indeed! good!".

Phrases of more than one word are formed by predicative, postpositional, coordinative, or subordinative (including appositional) combination of lesser free forms.

\section{3. 1. Word junction in the phrase.}

Characteristic of certain types of phrase is that word junction in them is accompanied by similar phonetic modifications, syntactophonemic features in this case, as we have seen occurring in morphology in the shape of morphophonemics (II. 1). This is not to say that such phenomena are always entirely absent in other phrase types or even in the wider context of the sentence, nor that in those phrases in which they are common they are obligatory. But they are rare in the former and frequent in the latter, and if in the latter they are not, strictly speaking, indispensable, they are yet very regularly observed.

Such types of phrase are notably postpositional and subordinative combinations, and those with the emphatic particle $j \varepsilon$; e.g., bum mele jahi jele, "and fat and round" (with postpos. jele, "with"); mandilin na or mandilim ma, "in cold, for cold" (postpos. na after $-m$ ); Hubulew fa (dial.) = Hubulew da, "to H." (postpos. da); hakaj sa = hakaj da, "for hakaj (a plant)"; foj sala, "very good", but na hala, "it (is) much"; nej seke, "his (own) garden", but $n \varepsilon j$ heke, "his (is) a garden, he has a garden"; $d_{\varepsilon j}$ hakaj bolu najkaj sala, "mine (is) very extraordinary

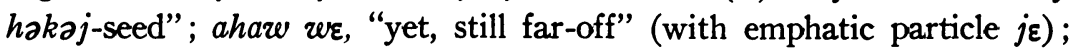
etc. If in other types of construction, notably coordinative combinations, we find similar features, we are justified in doubting whether they are at all syntactical or rather derivational and compasite (III. 2. 1), or at least in regarding them as borderline cases (III. 2.2), e.g., balaw sabakaj, "betel (and) tobacco", i.e. the ingredients of the betelquid, 
and hence "betelquid". As usual we shall write in our phonemicization only the heterophonemic variants, and in the case of $/ \mathrm{h} /$, the [s] allophone.

\section{4. Predicative constructions.}

There are four principal types of predicative constructions: (1) the verbal, (2) the nominal (including pronominal), (3) the emphatic and negative, and (4) the postpositional.

The first type consists of an inflected verb form as predicate which may itself express the subject or may be preceded by a separate word as subject. The predicate may or may not be accompanied by one or more attributes of V.7, types (8) and (9) hereafter, the latter (the object) as a rule intervening between subject and the predicate; e.g., ondofolo hadake, "the ondofolo (a clan chief) died"; Ajokoj anawole, "A. ate, was eating"; $k a^{\prime} j i$ nahi'bi durvaroke, "the (women's) canoe promptly sank"; bu na dilowfoke, "he dived off (over) into the water"; $k o$ awajjajde, "they are all the time peeling the coconut"; Jakali $n a-h u$ 'we ajboke $n \varepsilon j$ jo do, "they transported J. in the afternoon to his

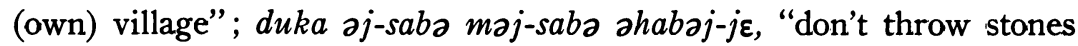
hither and thither" (lit. "...go-throwing come-throwing”); etc. The

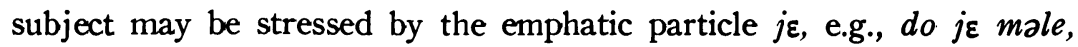
"a màn comes, it is a man who comes"; an no je dika na honole, "(it is) a banana tree (that) is lying yonder"; etc.

The second type consists of a subject followed by a noun, adjective (including the numerals) or pronoun as predicate; here too the predicate may be accompanied by an attribute (including paratactical appositions), e.g., da do Dajma, "my name (is) D."; ime kabam, "the house (is) big"; ondofolo fa be, "the ondofolo's children (are) two", i.e., "the o.

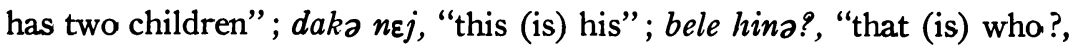
who is that?"; dako maka?, "this (is) what?"; wa fa amba?, "your child (is) where (or which)?; bele nəjह, "that (is) he, there he is". Here the predicate may be emphasized by the particle $j \varepsilon$, e.g., na ahaw we, "he (was) far away"; etc. The predicate has an attribute in examples such as ondofolo do hokolo, "the o. (is) a young man"; da ondofolo fa, "I (am) an ondofolo's child"; ime kaban sala, "the house (is) very big" (for *kabam hala); daka hina le habakaj, "this (is) whose tobacco?"; dika maka mej?, "this (is) for what purpose, what is this for?"; daka $d \varepsilon j$ m $j$ habakaj, "this is my tobacco, the tobacco for me"; $d_{\varepsilon j}$ heke ambaj, "mine (is) one garden, I have a certain garden"; amba nəjह wa fa, "where (or which) (is) he your child, where, which is your 
child" (in which the paratactical combination "he + your child" forms the predicate); etc.

The third type of predicative construction consists of a subject only followed by the emphatic particle $j \varepsilon$ or the negative bam, "not, hardly".

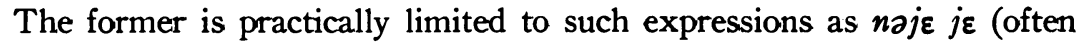
pronounced $n i j \varepsilon j \varepsilon)$, "that's him, that's it, there it is"; bam occurs in sentence phrases like do bam, "(there is) nobody" (lit. "no man"); aha buhi bam, "(there is) not a thing" (lit. "thing sort not"); etc.

In the fourth and last type of predicative construction the predicate following the subject is a postpositional phrase and hence consists of at least two words, e.g., bele ime hina le, "that house (is) whose?";

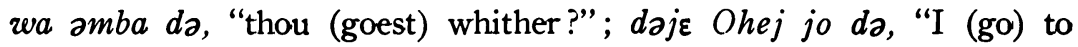

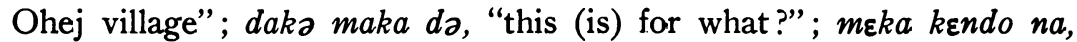

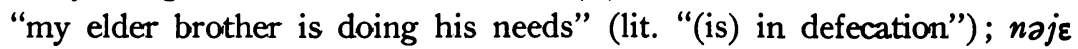
ime aj na, "he (is) inside the house" (lit. "in the house's inside"); etc.

\section{5. Postpositional phrases.}

Postpositional constructions consist of a noun, a pronoun or a verbal form followed by a postposition, or, except with verbal forms, a postpositional phrase as relation marker. The postposition is enclitic; e.g., if $a$ na, "in the (men's) canoe"; bu na, "in the water"; jo da, "to the village"; ime $d a$, "from the house"; do jele, "with the man"; $d a d \partial$,

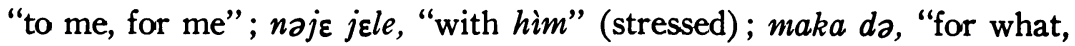
what for?, to what end?"; maka nə, "in what, because of what, why?"; bele na, "in that, because of that, therefore, hence"; $d_{\varepsilon j}$ na, "as mine, as my own"; dika na, "yonder"; hina le, "whose?"; makale na (or na), "in I came, i.e., when (or if or as or because) I came"; mokombonde na (or na), "when (or if or as or because) he will do"; dakakawna na, "because he awaited him"; adale da, "for I will see, i.e., in order that I shall see"; dowale do, "in order that we two will take" nundewboke da, "from (that) he disappeared, i.e., after he disappeared"; hadake $d a$, "from (that) he died, after he died"; etc.

If a noun is followed by an adjective, the postposition follows the latter, e.g., jo ahaw na, "in a far village"; $u$ kaban da, "for a big body, i.e. in great style"; do ambaj da, "to one (i.e. a certain) man"; etc.

In postpositional constructions consisting of a noun or pronoun followed by a postpositional phrase, the latter functions as a pseudo postposition itself, e.g., bu aj na, "in the water", i.e. "mid lake" (lit. "in the water's inside"); bu a na, "beneath the water, under water"; jakalo dan $d a$, "from up south"; na buko də, "to his presence, before him"; etc. 
The postpositional phrase may be stressed as such by the emphatic particle $j \varepsilon$, e.g., awfadake da $j \varepsilon$ maww'alewboke, "from (that) he wentdied even he came back to life"; awnundewboke da je mawjakalawboke, "from (that) he went-disappeared even he came-became visible again"; etc. It can also be repeated as such to indicate frequency or intensity,

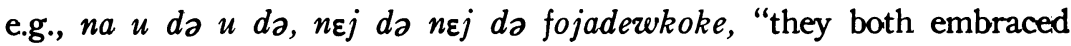
only their bodies, their own selves"; $n \varepsilon j d a n \varepsilon j$ da danojkoke, "they both pulled (it) to themselves, i.e., each to himself"; etc.

\section{6. Coordination of words.}

The coordinative combination of words to phrases can be realized either by mere juxtaposition, i.e., without coordinator; or - in nominal constructions only - by the usually, but not necessarily, repeated postposition de $\sim$ le or - more emphatic - jele, "with"; or again by be, "two, both", placed after the second constituent, if there are two. E.g.,

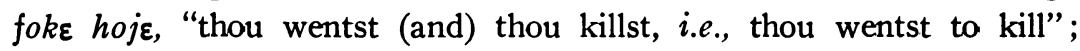
fokajde molajkoke, "they (pl.) went (and) buried"; ake kolukawna, "she went (and) held him"; fi ukake kajerwkoke nawole, "he chopped the sago, cleft (it), (and) picked (it out)"; 19 aj-saba maj-saba, "gothrowing (and) come-throwing, i.e., throwing thither (and) throwing hither"; kalu omi, "son(s) (and) daughter(s)"; aka beka, "kith (and) kin"; do mije, "man (or men) and woman (or women)" (but see for other possibilities of this combination, III.2.2); $\exists$ baw de Nakahabo le, "the Tortoise and the Lobster"; Jakali le Ajokoj de, "J. and A.";

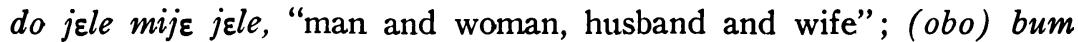
mele jahi jele, "(pigs) fat and round"; $\exists$ bala Jakali Hubulewe be, "both Jakali of $\exists$ balə (and) Hubulew"; etc.

As a specific syntactic type of word coordination must be regarded word repetition, syntactical repetition, that is, as distinct from morphological, both derivational and flexional, repetition (cf. III. 1, III. 2, and III.2.2). The two constituents are quite identical both in form (in the case of verbs in fully inflected form) and in meaning, nor is the meaning of the combination essentially changed, apart from being repetitive or frequentative; e.g., ja ja, "day (and) day, day (after) day, daily"; doko doko, "again (and) again"; fole fole, "he goes on (and) on"; anke anke (for anake anake), "he ate (and) ate, had eaten (and) eaten; awkajde awkajde, "the two (had) paddled (and) paddled";

19 Since a one word inflected verb form may also constitute a phrase, some of these verbal examples can also in a way be regarded as examples of phrase coordination. 
honkarena honkarena, "he burnt him (and) burnt him"; etc. The repeated form may be stressed by the emphatic particle $j \varepsilon$, e.g., Dajmə

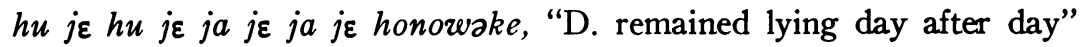

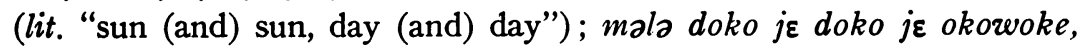
"again (and) again he poured out the (sago) pith"; etc.

Another specific type of serial coordination is represented by those "numerals" which are partly syntactical constructions (cf. III. 2.1); e.g., mahina be, "7"; mahina name, "8"; mahina kali, "9". For the fully syntactical "numerals", see V. 8.

\section{V.6.1. Coordination of phrases.}

For the coordinative combination of phrases the regular procedure is simple serial order without coordinator, e.g., amma dejmaj koma, "let us eat (and) make merry"; awnuke neko le buko da awole, "he rose (and) went to his father's presence"; Dajma kulum uke na ahamam dowke fala jadowkoke waku ambaj dowke joku ambaj jawawnohoke, "D. packed up, took his food, seized his bow-and-arrow, took a drum, (and) a dog accompanied him"; Dajma fi nawkoke mala dowke meke okowfake $n \varepsilon-k a$ mije olo, "D. picked out the sago, took the pith, descended, poured it in, (but) his elder brother's wife was not there"; etc.

However, contrastive coordination of phrases can, if stressed, be

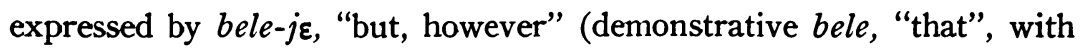

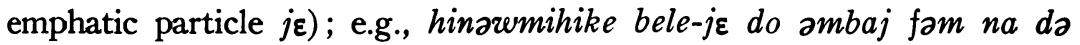
'ajej, "he asked them (for it), but not even one man gave (it) to him";

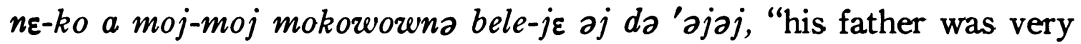
soft-spoken towards him, but he did not go inside"; da wej a ahi

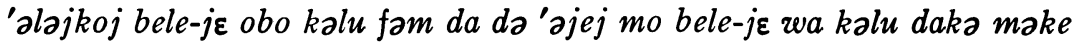
wa obo hownoboke, "I have not disobeyed your words, but a young pig even you did not give me, but hardly has your son here come (then) you slaughtered a pig for him"; etc.

Coordinative serial construction without coordinator is usual even where we would use clause or phrase subordination; e.g., ne-waw ukazena iso fonde, "his mother's brother told him to cross ashore" (lit. "told him (that) he will cross ashore"); do ahi ukaremi joku fokajde molajkoke, "other men he-told-them they crossed (and) they buried the dog", i.e., "he gave them an order, so that they crossed..."; mije wena make daka ja nahi'bi hadake, "the woman (who) came yesterday,

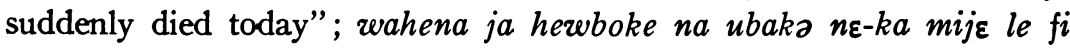
do awojde, "(when on) the morrow day had broken, his younger brother and his elder brother's wife went to the sago (bushes)"; $u$ foj dowke 
nakawmake, "(after) he had recovered (lit. had got a well body), he remained sitting"; hokolo be kokokajde na ubaka Hebsjkoj Dajma adakazena, "(while, as) the two young (girls) did their work, her (i.e. the) younger sister H. saw D."; etc.

But often particles like mo, "just, only, but"; and nahi'bi, "suddenly, promptly", occurring after the subordinate clause and before the head respectively, may serve as pseudo coordinators, e.g., nawmeke mo

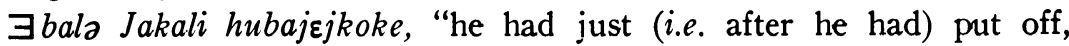
(then) $\exists$ balo Jakali (and he) met"; nakawkoke mo dala ikajnale, "he had but just settled, sat down, (with them), (then) they gave him goods";

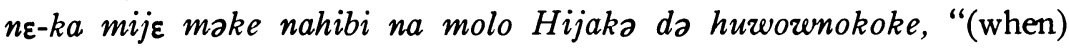
his elder brother's wife had come (home), she promptly informed her husband H."; ne-ka ikawna nahibi wawna, "(after) her elder sister had given (it) to her, she suddenly said..."; dowke mo nahi'bi ojbojowboke, "he had only just taken (it), (then) promptly it fell apart"; Dajma jo da make mo nahi"bi ne-ka mije na da ake, "D. had only just come home, (then) promptly his elder brother's wife went to him"; Dajma mawwawdike mo nahi'bi $i$ fownanake, "D. had hardly arrived, (then) he jabbed at him with fire"; etc.

However, for subordinate clauses, see also the section on subordination of phrases hereafter.

\section{7. Subordination of words.}

There are ten types of subordinative combination of words: (1) noun and nominal attribute (noun); (2) noun and noun in paratactical apposition; (3) noun and nominal attribute (adjective, including numerals); (4) noun (including gerund) and pronominal attribute; (5) noun and verbal attribute; (6) adjective and adverbial attribute; (7) adverb and adverbial attribute; (8) verb and adverbial attribute; (9) verb and object or goal; and (10) combination of types (1) and (4) to form possessive phrases.

In type (1) the attribute precedes the head, and the function is that of a generalized relation of possession or origin. We have already briefly mentioned this type in III. 2.2 on borderline cases; e.g., aka'la obo, "jungle (i.e. wild) pig"; joku falam, "dog's head"; ondofolo fa, "chief's child"; ondofolo i'fa, "chief's canoe"; etc. The attribute may be accompanied by the postposition $l e \sim d e$, "with", to indicate a possessive relation in the sense of "having something on or with one". The attribute in this case is itself a (postpositional) phrase, e.g., ondofolo le fala, "the chief's bow-and-arrow" (that he has with him); Dasim 
Kalawbew de omi, "D.K.'s daughter" (whom he has with him); ne-waw de joku, "his uncle's dog"; joku le falam, "the dog's head"; etc.

In type (2) the apposition follows the head, a slight pause intervening,

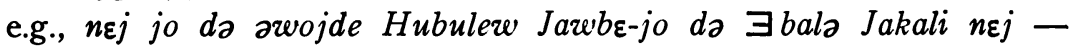
$\exists$ bala-jo - $d \partial$; "they both went to their own villages, $H$. to Jawbe village (and) Jakali of $\exists$ balə to his - the $\exists$ balo village"; Ajokoj - Dasim Kalawbew de omi - ake kolukawna, "A. - D.K.'s daughter - went (and) held him"; etc.

The adjective (and the numeral) of type (3) follows the head, e.g.,

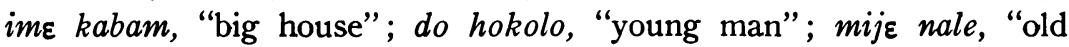
woman"; fa hokolo, "young child" (as distinct from the composite form hokolo-fa, "the younger or youngest child of a family"; cf. III. 2.1); fa bəna, "an older child" (as distinct from bəna-fa, "elder, eldest child"); ja ambaj, "one day, a certain day"; hokolo be, "the two young (ones)"; do name, "four men" etc.

If the noun is accompanied by a pronominal attribute, demonstrative, interrogative, or possessive (type 4), the latter precedes the head, e.g., bele do, "that man"; daka ime, "this house"; dika no, "yonder tree (trunk)"; nə falam, "his head"; na damə, "its tail"; da ime, "my house"; $d a$ or do shamam, "my food"; $n \varepsilon j$ jo, "his (own) village";

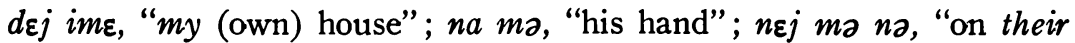
hand" (i.e. "at their expense instead of his own"); $w_{j} j \mathrm{~m} \varepsilon$, "your due";

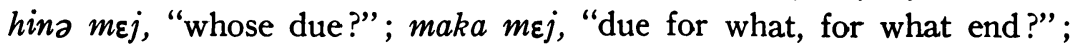
$n$ - $\partial j$-aj (contracted from $n a$ or $n \partial \partial^{2} \partial j$ ), "his going" (gerund); na $b \varepsilon j-b \varepsilon j$, "his seeking, the seeking of him"; $n$-əjdi $n$-oj-oj, "its going up (and) its falling down"; etc. The attribute may be accompanied by the postposition le $\sim d e$, "with", as possessive, e.g., hina le ime, "whose house?"; etc.

Type (5) consists of a noun followed by a finite verb form which, however, has not finite, but participial or relative, function, e.g., do hadake, "man (who) died, dead man". Hence this construction, which is, moreover, restricted to standing expressions like the one mentioned, is really only functionally subordinated (as from our point of view), but structurally it is not essentially different from the serially coordinative type of construction of phrases mentioned in V.6.1, $3^{\text {rd }}$ para.

The adverb which determines an adjective (type 6) follows it, e.g., foj sala, "very good" ( $s$ for $h$ after $j$ ); hele najkaj sala, "a very loud

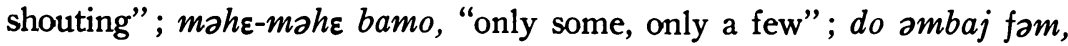
"even one man"; do halan nam, "so many men" for *halam + $f a m \sim h a m)$; etc. 
If the adverb determines another adverb (type 7), it has the same position, e.g., wala wala hala, "very quickly"; foj moj sala, "very exceedingly good"; etc.

As attribute of a verb the adverb (type 8) may either precede or follow the verb, the former position being favoured, notably (but not exclusively) when the adverb is stressed, e.g., nahi'bi duwawoke,

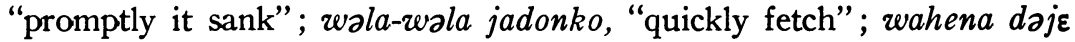
kulum udale, "to-morrow I shall pack up"; banam dilowfoke, "again he dived"; nawa dowke, "you've got it indeed, all right"; but also: duwke mo fam, "it only just fell, started falling"; w-omi Jakali dowke nahi'bi nej molo da, "thy daughter has suddenly taken J. for her husband"; nabe u nabe wa jewboke ama-foma, "it was restored entirely in its original condition"; etc.

If the verb has an object for attribute (type 9), the latter as a rule precedes the former, e.g., fi ukake, "he beat the sago"; dejmaj koma, "let us make a feast"; na kada-nalo arusajawboke, "he squandered his possessions"; $i$ fownanake, "he jabbed fire at him"; na kada-nala wahewmikoke, "he divided their goods to them"; aka mije jawawnohonde, "thou wilt accompany thy elder brother's wife"; etc. But for reasons of emphasis the order is sometimes reversed, e.g., wala-wala jadonko malo, "quickly bring here clothes"; adajnobo aha!, "lóók at the thing!"; etc.

The object may be qualified or stressed by a postposition, in which case the attribute is itself a two word phrase of the postpositional type (V. 5). Postpositions are the rule, of course, for an indirect object or, with intransitive verbs denoting a movement, for the direction. But just as in the forementioned examples the incorporated object affixes

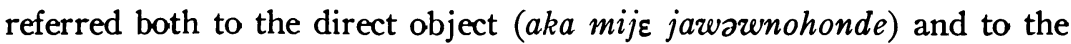
indirect object ( $i$ fownənəke and kadə-nala wahewmikoke), a postposition may refer to a direct or an indirect object. The use and the choice of postpositions with the object depends on the nature of the action expressed in the verb. In so-called intransitive verbs as a-, "go", etc., a postposition indicates the direction of the movement, e.g., jo da $a k e$, "he went to the village"; ime da owoke, "he descended from the house"; etc. Similarly in Dajma da wawna, "he-said-to-him to Dajmə", Dajma is the indirect object with the postposition $d a$ to the verb wa-, "say to, tell", which is at the same time inflected for this same indirect object by the person object affix -na. And the same situation is found in Hijaka da huwaronokoke, "she related (it all) to H.". But in joku

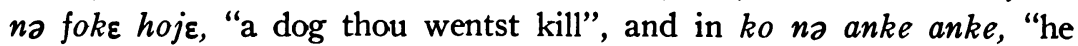


had eaten coconuts", it is the direct object, which is accompanied by the postposition na, "in".

Type (10) lastly, contains two subtypes: (a) one in which the combination consists of a single noun as head preceded by a two-word phrase of type (1) or (4), with a noun, interrogative pronoun, or the emphatic possessive, plus $m \varepsilon j$, "due", as attribute; and (b) one in which the combination consists of a single noun as attribute, followed by a two-word phrase of type (4), with the normal possessive of the $3^{\text {rd }}$ p. na $\sim n a$ plus another noun, as head. The first subtype denotes a relation, possessive or other, in which the head is the due of, is the thing destined or meant for, the attribute, e.g., Nakahabo $m \varepsilon j k o$, "the Lobster's coconut (his due, his part)"; hina mej habakaj, "whose

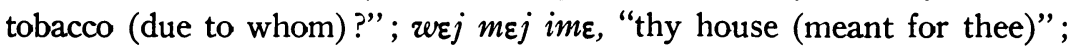

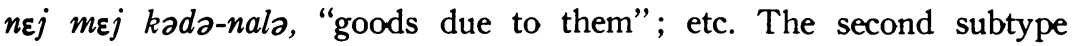
denotes a specialized relation of origin or possession, as distinct from the generalized relation of type (1); e.g., joku na falam, "the head of the dog", as distinct from joku falam, "dog's head"; Dajma na joku, "D.'s dog"; am oloku na fe, "oloku-banana leaf", as distinct from am $f_{\varepsilon}$, "banana leaf" (generally); ondofolo na $f a$, "the chief's child", as distinct from ondofolo fa, "a chief's child"; Dasim n-omi, "D's daughter"; ondofolo na fala, "the bow-and-arrow of the chief"; etc.

\section{7. 1. Subordination of phrases.}

As we have said, phrase coordination is usual, even where we would have to translate with a subordinate phrase or clause (see V.6.1). For clause subordination, however, there are other possibilities. In subordinate clauses the postposition na $\sim n a$ may be used in the sense of "when, if, as, for, since, because". This meaning of the postposition has already been noted in dealing with the postpositional phrase; here

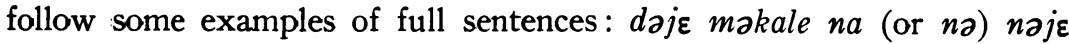

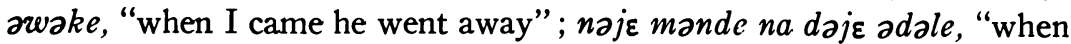
(or if) he comes (lit. "will come"), I shall go away"; na u kaban da ake nakawole na, "as he went (and) lived in great style"; Jakali dakakarwa an na Hubulew bu moko da irvole, "since J. had not waited for him, H. went up the open lake" (lit. the water's mountain) (thus in the version of this story published in the Bijdragen, cf. the Introduction); but also Jakali Buki na dakakarena am, Hubulew..., "(as) J. had not waited for him in the Buki, H...." (without causal na; thus in the version published in this book); etc.

Conditional clauses can also, of course, be subordinated by means 
of the inflected verbal forms of the conditional, e.g., jej bi foma do do

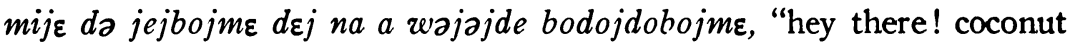
rat, if thou shouldst become man (or) woman, thou wouldst understand my words (lit. voice) (that) I would say to thee".

\section{8. The parts of speech.}

In the foregoing sections we have mentioned several types of words with the distinctive names of the traditional parts of speech. These distinctions are obviously based on structural, morphological and syntactical, features, characteristic for them, which will be clear enough from the examples cited. But on some points further explanation and justification seems necessary. It will be clear, for instance, that the verb is characterized as such by its flexion; that the noun and the adjective are distinguished from each other by their different syntactic positions in word subordination with another noun; the demonstrative pronoun from the adjective by its similar syntactic position as the noun's, and the personal pronoun from the noun by its pseudo-flexion of "genetive" (possessive) forms through apophony. But some doubt may be justified as for the "adverbs" and the "numerals". Notably the latter allow more than one interpretation.

The "adverb" has no specific characteristics to distinguish it from the noun or the adjective. Often nouns can function as adverbial expressions, e.g., huwe, "evening, afternoon", but also "in the evening"; məkaj, "manner, way", but also "apparently"; etc. Similarly adjectives may function as adverbs, e.g., nahinki, "sufficient(ly)". The syntactic position of the "adverb" as attribute to the adjective is not different from that of the adjective to the noun. But many "adverbs" occur only as such, i.e., as attributes to adjectives or verbs, and never occur as adjectives to nouns nor as nouns themselves, e.g., nahi'bi, "promptly, suddenly, further"; manam, "still, yet"; $b a$, "only, just"; mo, "id."; bamo, "id."; bamba, "exceedingly, violently" (bam, "not" + ba, "only, a little") ; mana, "to-day"; wena, "yesterday"; wahena, "tomorrow"; etc. Some are apparently formed with a preposed $n a$ or na, which may be none other than the $3^{\text {rd }}$ p.s. pronoun as a possessive or a demonstrative (cf. III. 2.1 and III.3.1), e.g., $n a-h u^{\prime} w \varepsilon$, "in the evening, evenings"; na denijaj, "in the night, of nights"; and possibly also the example already mentioned, nahi'bi. Others seem to be distinguished by repetition, e.g., dala wahawowmi, nahinki-hinki jejwowmi, "he dealt out to them goods, sufficiently he gave to them"; but bele nahinki bamo, "that (was) just sufficient". But in such cases the repetition may 
represent intensity rather than adverbial quality. Also many "adverbs" seem to have an irregular stress, notably final stress even when the

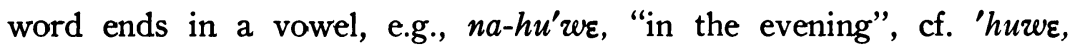
"evening", with normal stress; nahi'bi, "suddenly"; and with both irregular final stress and repetition wa'la-zwa'la, "quickly". But, as we have seen (III. 2) repetition is found in several adjectives as well; and irregular final stress also occurs in other words. Yet the latter seems to be more frequent in such "adverbs".

As to syntactic position in relation with the verb, the relative freedom of the "adverb" as compared with other attributive word-types is certainly a specific feature, cf. the examples cited: nahi'bi duwarwoke, "suddenly it sank"; but also dowke nahi'bi, "she took suddenly". All evidence taken together, I feel justified in regarding the adverbs as a separate part of speech, although it must be admitted that its distinctive features are not very pronounced.

The "numerals" I have included in the adjectives. But a different interpretation is, for some historically at least, equally possible. The lower numerals 1-4 are, as far as we can judge at present, independent words: ambaj, "1"; be, "2"; name, "3"; kali, "4". They follow the noun to which they refer and therefore can be classed as adjectives. But if the construction of noun plus numeral is taken as a subordinative combination of type (1) in section V. 7 (noun plus noun), these numerals can also be regarded as nouns, meaning "unit"; "pair"; etc. And certainly nouns are, historically at least, the higher "numerals" which appear to be formed with names of parts of the body, e.g., mahambaj (<ma $f_{\varepsilon}$ ambaj, "one hand-palm"), "5"; mahina ambaj, "6"; which are derivational and partly derivational partly syntactical respectively (cf. III. 2.1 and V.6); ma be, "10" (lit. "2 hands"); ma be odo fe ambaj, "15" (lit. "2 hands, one footsole"); $u$ ambaj, ("one body") or odo be ma be ("2 feet, 2 hands"), " 20 "; etc., which are fully syntactical. For the sake of simplicity and unity, however, we do not distinguish between the various types for our classification as part of speech.

\section{9. Tense and aspect in the sentence.}

As we have already briefly indicated in III. 4. 4, the tenses, as I have named these categories, have also other properties than those relative to time. The present represents an action still continuing at the moment of observation or envisaged as such in descriptive statements, and it is, therefore, durative, imperfective and indeterminate, but in the present, e.g. $\exists$ baw imoli da danole Nakahabo ube da danole, "the 
Tortoise pulls from the stern, the Lobster pulls from the prow". The imperfect has been named so for its similar durative, i.e. imperfective and indeterminate, quality, but envisaged for an action in the past, e.g. Ajokoj na ka'ji na ahamam anəwole, "A. ate her food in her canoe"; Ohej jo na nakawole, "he lived at O.". The aorist, on the other hand, is a past punctual, a momentaneous past. It represents the action at the same time as momentaneous or having lasted only a very short time and as finished. It is, therefore, determinate and perfective even in its primary form. It is also used in contexts, where we would use a perfect or even a pluperfect. In its repeated form (cf. V.6) it stands for intermittent short or momentaneous actions, repeated by intervals. Examples: nabe ko ma nake dowke mo nahi'bi na ma na ojboj-owboke, "he stretched out his hand (to) that coconut just mentioned, took (it), then suddenly it fell apart in his hand"; $\exists$ bala Jakali Burvaj jo da make Ohej jo na make nakawole, " $\exists$ bala Jakali came from Buwaj village, came in Ohej village, and stayed (living) (there)", with make in the aorist, but nakawole in the imperfect; foma ambaj ko na anke anke jele, "a coconut rat, after he has eaten (and) eaten (with intervals) coconuts, comes up", with repeated aorist followed by the present; Hijaka honkawna honkawna Dajema a da owduwke, "H. burned him (and) burned him, (and) D. fell down"; balakajde balakajde mo $\exists$ baw Nakahabo da wawna..., "(after) they two had plunged (and) plunged, the Tortoise to the Lobster said-to-him ..."; etc.

The primary future is more or less indifferent to aspect, and so are the primary adhortative and conditional, while the primary habitualis, as the name indicates, is durative. However, see more in detail, infra.

The so-called "tenses", therefore, also have largely aspectual value even in primary form. The secondary forms, however, which are formed with what I have named the aspectual affixes (see III.4.4), are aspectual in this sense that the action is envisaged as to its goal, either - in the case of transitive verbs - with reference to an "object", direct or indirect, or - in the case of both transitive and intransitive verbs - with reference to direction, either in space or in time, or to self. The secondary forms are, then, determinate as to effect on goal, whereas a perfective primary tense, as the primary aorist, is determinate as to duration of action, the imperfective tenses being indeterminate. This determinating power is characteristic of the aspectual affixes. Hence they are very frequent with the only really perfective and determinate tense, the aorist, if this refers to a definite object, and practically indispensable with it if at the same time it takes a personal 
object affix. As a rule, though not always, the object affix then refers to the indirect object, the aspect affix referring to the direct goal as described above, which statement must, however, be qualified by the reservation that "object", "direct" and "indirect" in this connection need not always correspond to the English conceptions; e.g., $i$ fownanəke, "he jabbed fire at him" (in which $i$, "fire", is the direct object, and the obj.aff. -na- refers to the indirect object); na kada-nala wahewmikoke, "he divided their goods to them" ("goods" being direct, and -mi-, "them", referring to indirect object); but in aka mije jawawnohonde, "thou wilt accompany thy elder brother's wife", the object affix -no- refers to the direct object aka mije itself. See also the discussion in V.7, type (9).

Exceptions to the foregoing are found in certain verbs which by their nature already imply a specific effect on a direct object and hence omit the aspect affix, but always take a personal object affix for the indirect object, e.g., ukarena, "he said to him, told him (words)" (aorist); kolukawna, "he held him (by the hand or shoulder, etc.)"; etc. On the other hand some transitive verbs appear consistently in the primary aorist, without either aspect affix or object affix, e.g., dowke, "he took, received". For intransitive verbs absence of a direct object is, of course, the rule, but an indirect object may be added, e.g., $k i$ owowna, "saliva dribbled-him (lit. "descended-him"). If an intransitive verb occurs in the secondary aorist with a directive aspect affix, it is more or less inchoative, e.g., owoke, "he descended" (i.e., "he started to descend").

For similar reasons as make them so frequent with the perfective aorist, the aspect affixes are incompatible with the really imperfective tenses: the present and the imperfect, even when they refer to a direct object, and even when they take a personal object affix. Examples:

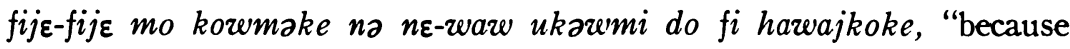
he acted on only in that manner, his mother's brother ordered people (and) they loaded the sago" (in which the asp. aff. -ma- indicates a hitherward movement in time: the $3^{\text {rd }}$ p. pl. obj aff. -mi- added to the primary aorist of "say to, tell" refers to $d o$, "men"; and the active transitive asp. aff. $-k o$ - to the dir. obj. fi, "sago"); nawmeke mo $\exists$ bala Jakali hubajejkoke, "he had just put off, (then) he met (lit. they two met!) $\exists$. J." (in which -me- indicates a movement away and downwards in space); hokolo be do jele mije jele jejbokajde nakajake, "the two young (ones) became (and) remained (settled as) husband and wife" (in which je-, "give", with medial asp. aff. -bo- means "become"; and 
the asp. aff. -a- in nakajake indicates a movement away, onward, in time); Hubulew u bana mo je nakarenamake: mahe mokodambonde?, "In H.'s body only the thought came to dwell along: how shall I do to him?" (in which the dir. asp. aff. -ma- in nakawnamake indicates a direction hither in time; the obj. aff. -na- in the same word refers to H.'s body; and the obj. aff. -am-. for -an- in the last word refers to H.'s companion); do-mije ma koluwajna $u$ ahuwboj, "the people hold him by the hand (lit. hold his hand for him), he doesn't feel it" (in which ma, "hand", is the dir. obj. of the present koluwajna, and this obj. aff. -na refers to Jakali); Ajokoj ake koluwkawna wa a hilawboke, "A. went (and) held him, then only he (lit. his voice) was silent" (in which -no in the primary aor. koluwkawn refers to Jakali, and the asp. aff. -bo- is medial) ; Ajokoj he'le ka'la najkaj mokowboke, "A. made a loud crying (and) shouting" (in which -bo- is medial, but transitive); joku no falam folowkoke, "he cut off the dog's head" (with active transitive -ko-); but no aj da folowdike akanawdike, "he cut (and) hacked upwards from the tree's inside" (with asp. aff. -di-indicating an upwards movement); na mije Hijakə do huwownokoke, "his wife told-him H. (everything)" (with asp. off. -ko- referring to all that happened, and obj. aff. -no- to Hijakə); hokolo be jo da awajmake, "the two young (ones) rowed home to their village" (in which asp. aff. -ma- indicates a movement hither, i.e. here, homeward, in space); mala

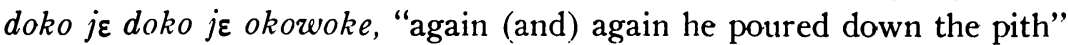
(with asp. off. -o- indicating a downward movement); but doko ahi meke okownahake, "another time he went away-down (and) poured (it) in for her" (with asp. aff. -ha- indicating the filling of, the doing into, the sago-container, and obj. aff. -nə- to Dajmə's sister-in-law); cf. also mala dowke meke okowfake ne-ka mije olo, "he took the pith, went down-off (and) poured it in, (but) his elder brother's wife wasn't there" (with dowke as always without any asp. aff.; and okowfake without an obj. aff., because the person of the indir. obj. was away); $k a^{\prime} j i$ dan do jewelewfoke, "he climbed out over on the canoe" (with roots $j e$-, "climb", and ele-, "come, jump forth, appear", in composition and with asp. aff. -fo- indicating a crossing, going over movement, in casu over the canoe's side); but nine jejelerboke ka'ji dan do, "they two jumped forth up on the canoe" (with medial -bo- in the same composition); nəbam ba wa do mokowbokawale, "badly I have behaved to thee" (with medial $-b o-$, and obj. aff. -wa- of $2^{\text {nd }}$ p.s. referring to indir. obj. already indicated separately by wa da); ヨbaw nabe ko dowke kondघw adunzwnokoke howaka adunawnokoke nabe u nabe wa

Verh. dl. 47 
mokownokoke jawole, "the Tortoise took that coconut just mentioned, closed (again) the (cleft halves of the) shell, closed (again) the (loose parts of the fibrous) husk, made them into the original state (lit. body of before, shape of before), and sank (viz. in the water)" (in which dowke as usual has no affix, the asp. aff. - $k o$ - refers to the loose parts and the obj. aff. -no- to the coconut, while jawole is in the imperfect); na-naka ahamam mokozenahake, "his mother prepared food for him" (the obj. aff. -na- referring to the son, and the asp. aff. - $h a$ - to the putting into a container of the food); $n \varepsilon j$ do $n \varepsilon j$ do danojkoke, "they two pulled (it) each to himself" (with asp. off. $-k o$ - in reciprocal function); and similarly: $n \varepsilon j$ do $n \varepsilon j$ do fojadervkoke, "they two went (and) embraced only each other"; etc.

The apparent inconsistency in the foregoing discussion, viz. the habitualis, which is durative and hence imperfective, but yet can take an aspect affix, is not really inconsistent. For although in its totality extending over a large segment of time, the action of this tense need not be continuous. It may consist of a series of single units which each in itself can be envisaged as momentaneous or of very short duration and as such perfective. The effect of the aspect affixes on the habitualis is, then, to transform it into a series of repeated single goal-determined actions, a kind of iterative, therefore, determinate as to goal; e.g., $d_{\varepsilon j}$ heke ambaj ada bolu bam honojale, "I have a garden (but) it lies all the time (i.e. continuously) without seedlings" (in which honojale is in the primary habitualis); ja ja daje mokojjale, "day (and) day I am used to work" (continuously, primary habitualis); $a m f_{\varepsilon}$ habakaj do olejjajde, "they use to roll banana leaf for tobacco" (as before); ko bojjajde bojjajde makaj, ko ahejjajde ahejjajde makaj, "they are chopping the coconut apparently, they are peeling the coconut apparently" (as before); but Ajokoj hajejkojowna Jakali ka'la najkaj sale mokojbojole; bele na Ajokoj ikalajbojowna, "every time (i.e. every single time) Ajokoj let him loose, Jakali made a terrible uproar; therefore A. every time got hold of him (again)" (in which the asp. affixes $-k o$ - and -bo- turn the action of the three habitualis forms concerned into a series of repeated single actions of short duration determinate as to goal); fo bam wali bam ajajnujans, "without fear (and) without life (expression for "carelessly") thou goest-behavest thyself every time" (as before; with reflexive affix -nu-); fole fole no na ajnuwbojole (for ajnuwajbojole) jejkojole a'hamam anajkojole balaw sabakaj kojkojole ajnujale alojkojowna, "going on and on (lit. he goes across, he goes across), he uses to sit down now and then (i.e. 
intermittently) if tired (lit. in fatigue), take a breather, eat food, prepare a betel quid, (then again) to rise (and) to continue his way" (in which fole is in the present, and the other verbs are all in the secondary habitualis or iterative, resp. with medial $-b o-$, active transitive $-k o-$, and reflexive $-n u$-) ; etc.

A similar distinction in determination as exists between the aorist and the imperfective tenses, is found between the secondary future and the primary future. Hence the distinction between primary and secondary future is very much like that in modern Greek between a futurum praesentis (or continuum) and a futurum aoristi (or absolutum). The same is, mutatis mutandis, the case for the distinction between primary and secondary adhortative and primary and secondary conditional. Examples: ukawna hondombi fonde folonkonde, "he told him to go across (and) cut hondombi" (lit. "he told him he will go across (and) will..."; in which fonde is in the primary future, but folonkonde has the asp. aff. -ko- referring to hondombi 20 and determining the action as to this object and perfectivating it as to time); foj am fe kamawbonde dawawmande, "go across to (lit. thou wilt) tear off a banana leaf (and) to (lit. thou wilt) bring it home" (with asp. affixes -bo- and -ma-); mahr mokodambonde?, "how shall I act towards him, what shall I do to him ?" (with medial -bo- and obj. aff. - $m$ - for - $n$ - referring to the indir. obj.); hakaj bolu fam bale dawawfamande ba?, "wilt thou bring me some more hakaj seedlings?" (with asp. aff. -mə-, "hither", in dar'ə-, "take", which makes "bring"; and with obj. aff. $1^{\text {st }}$ p.s. -fa-, dial. for -də- after -w-); baləjsa ədabom, "open (it) (and) let us two see" (adhort. $2^{\text {nd }}$ p.s. with asp. aff. - $h a-$ referring to the things in the package; and adhort. $1^{\text {st }}$ p.du. with

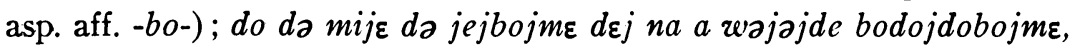
"if thou shouldst become man (or) woman, thou wouldst understand my words (that) I would say to thee" (in which $j e-$, "give", plus medial -bo- makes "become"; bodo-, "hear", plus -bo- makes "understand"; the obj. aff. -do- refers to the indir. obj. "me", the dir. obj. being $a$, "voice, words"; while wajajde must contain the obj. aff. -jaj- of the $2^{\text {nd }}$ p.s., but must not take an asp. aff.); etc.

After the foregoing there seems to be no further need to give examples of the use of the aspect affixes in the uninflected and partly inflected forms: the gerund, the negative and the vetative.

20 See the vocabulary i.v. 


\section{SPECIMEN TEXTS.21}

\section{1. Fa nundewboke da $\mathbf{j} \varepsilon$ dowkajnəle.}

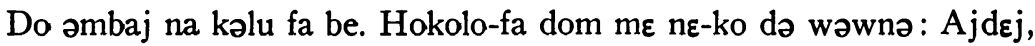
jejdoko dej mej kədə-nalə dom. Na kədə-nalə wahewmikoke. Nə ja məh $\varepsilon$-məh $\varepsilon$ bam mo bele da, na hokolo-fa dom na kədə-nal $\varepsilon$ na nəmə nə adiləwole, alownokoke, jo ahaw də əwole. Dikə nə na kədə-nalə əwsajəwboke, na u kaban də əke nəkəwole nə. Bele jo əj nə moni-maj kabam nəke. Bele jo na do əmbaj də əke əwnəhikewnuke. Bele do ukəwnə na heke də n-obo kaja də. Nə jahələ də ambonde də obo mej

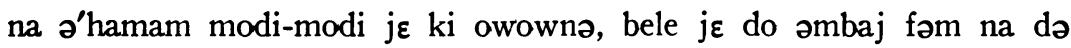

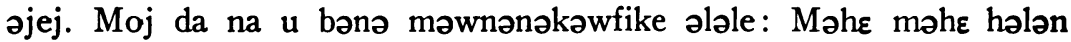
nəm me-ko le ufoj əhamam na hələm mele əkajjadajde; da bekə nə moni nə məkakəlele. $\mathrm{Da}$ adununde me-ko le buko də ədəle də, me-ko

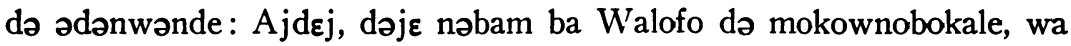

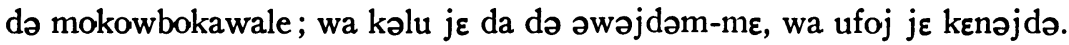

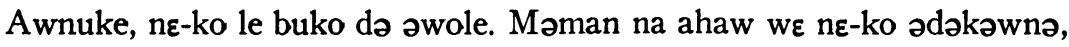
hakawboke na kəlu le $\mathfrak{u}$ də, dowkəwnə, joj-bulu hunəwownə, kəna

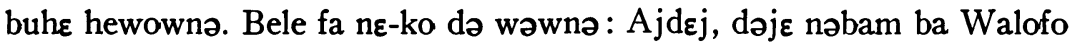

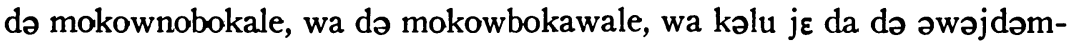

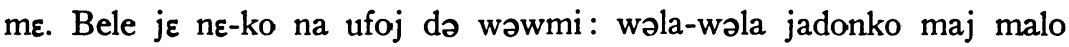
foj moj mənnəhidənko, ojbo na mə nə mənnənə, odo məmalu mənnəhidənko. Obo bum mele jahi jele dəwəm mənnənsa. Amma, dejmaj

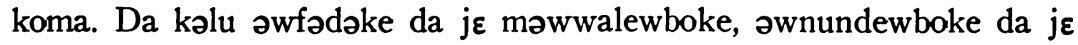
məwjakalawboke. Nine anəwajde, dejmaj kowajde.

$\mathrm{N}$ fa bəna dom heke nə əkənəkəwole. Ime də məwole nobew-

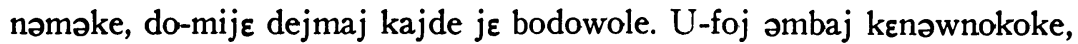

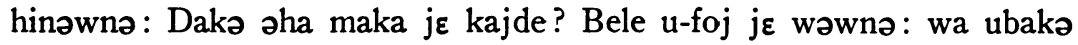

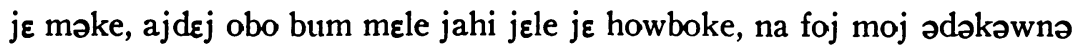
nə. $\mathrm{Na}$ bəna-fa ikələ kowole, əj də 'əjəj nəkəwole. Bele nə nв-ko

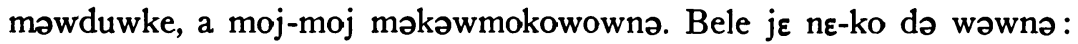
Bənə nəkəwəw; dakə dalo hələn nəm ba da wa də mo uhejməjawale,

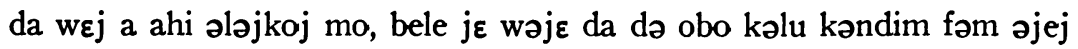
mo, da dej sokolo-wafew wele dejmaj kande. Bele je wa kəlu dakə də

21 See the comment on these texts in I. 1. 
bam, wa kədə-nalə mije a menkə a də əwsajəwboke, wa obo bum

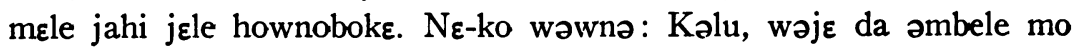

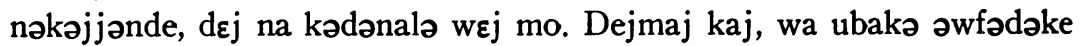

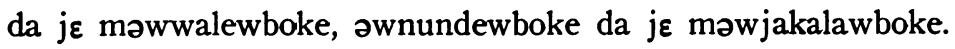

\section{2. $\exists$ balə Jakali le Ajokoj de.}

$\exists$ balə Jakali Buwaj jo da məke, Ohej jo nə məke nəkəwole. Nəjє menkə fa kabam.22 Doko əmbaj ne-waw ukəwnə jo-kiki i'so jokoluwej

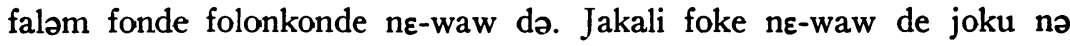
faləm folowkoke hawəwkoke məke. $\mathrm{N} \varepsilon$-waw də foke, wəwnə: Awaw, nabe joku faləm na də folowkokale hawəwkokale məkale, i'fa na. Dasim Kələwbew kulu-kulu jewboke: Waj di məh $\varepsilon$ ! Hondombi ukawale, wa isom ba joku nə foke hoje. Do əhi ukəwmi joku fokajde molajkoke.

Doko əhi ne-waw wəwnə: Foj əm $f_{\varepsilon}$ kaməwbonde dəwəwmənde. Jakali foke əm $f \varepsilon$ kan-kam fələ-fələ kajke kajke məke. NE-waw də

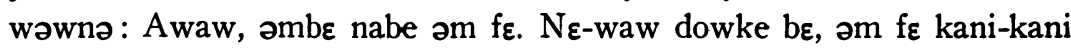
daməle. Dakə maka mej? Jakali wəwnə: Awaw, nabe ukad $\varepsilon$ əm $f \varepsilon$,

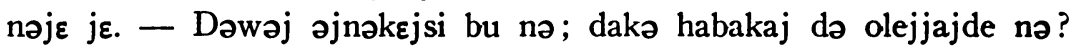
Jakali əwnəkewsike.

Fije-fije mo kowməke nə, ne-waw ukəwmi do fi hawajkoke. Ja hewboke əke i'so də. Fi nəkajde nəkajde, Jakali əha amə-amə mokownoboke. Ka'la mo kenəwəke. Do-mije mə koluwajnə u əhuwboj. Nə ka'la mo kenəwəke. A jokoj, Dasim Kələwbew de omi, əke koluwkəwnə, wa a hiləwboke. Ajokoj hajkojownə Jakali ka'la najkaj sələ mokojbojole. Bele nə Ajokoj ikələjbojownə. Nej məkaj mo kowəke.

Jo də fokajde, Dasim wəwmi : Nahibi ambo onnəhambo. Jakali le Ajokoj de nə ka'ji nə jawojde. Ajokoj nə ka'ji nə ə'hamam anəwole.

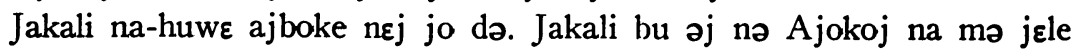
hundam kojəke. Okajde jo nə ime wa-kundam mewojde Jakali nahi'bi adewnokoke ka'la: Wo $\exists$ balə d $\varepsilon$ mije, wo $\exists$ balə d $\varepsilon$ mije! Ajokoj he'le ka'la najkaj mokowboke, he'le bamba. Ohej do-mije əkajde Dasim Kələwbew də wajnə: W-omi Jakali dowke nahi'bi nєj molo də. Jakali doboni dəla wahewowmi, nahinki-hinki jewowmi. Dasim a 'ələj. Ninع bamo emem dojaw, bele məkaj na na-hinki bamo. Nej məkaj hokolo be do jzle mije jele jejbokəjde nəkəjəke.

\section{3. ヨ balə Jakali le Hubulew de.}

Ja əmbaj Hubulew Ohej jo də dəla kaje də. Nəwmeke mo $\exists$ balə

22 menk $\theta-f a$, "sister's child", i.e. the child of the sister of Dasim Kolowbew mentioned hereafter. 
Jakali hubajejkoke.23 $\exists$ balə Jakali hinəwnə: Ako, wa maka də? Hubulew wəwnə: Ako, da Ohej jo də dəla kaje də. $\exists$ balə Jakali Hubulew fə wəwnə: Ako, da Buki nə dakədəjde. Hubulew Ohej jo də iwole. Ike Wajəna bohi da oke. Nəkəwkoke mo dəla ikajnəle, nine woke məwole. $\exists$ balə Jakali Buki nə dakəkəwnə am, woke bu moko də iwole. Ike bu moko nə hubajejkoke. $\exists$ balə Jakali hinəwnə Hubulew fə: Ako, nend $\varepsilon$ dəla ikajejde? Hubulew wəwnə: Nə, ako, ikajsəle. ${ }^{24}$

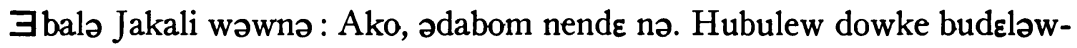
fake, ədəjboke mo $\exists$ balə Jakali wəwnə: Ako, bu nə wajom, fakom-

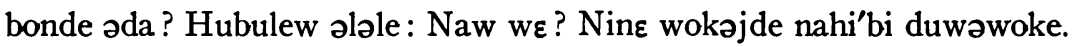
Hubulew ka'la najkaj sələ kowownə $\exists$ balə Jakali də. Nəbə da mo Buki də məwojde. Buki nə nəkəjkoke n $\varepsilon j$ jo də əwojde; Hubulew Jawbe jo də, $\exists$ balə Jakali n $\varepsilon j \exists$ balə jo də. Məwojde bu moko nə mo $\exists$ balə Jakali Hubulew fə wəwnə: D $\varepsilon j$, ako, dej heke əmbaj, əda bolu bam honojəle. Həkəj bolu fəm bəle nəwfande məwfəjende? 25 Hubulew wəwnə: Ako, dahe nə; dej həkəj bolu najkaj sələ. Hubulew əke new bolu də mo folowkoke məke ikəwnə $\exists$ balə Jakali də. $\exists$ balə Jakali nвj seke nə molowkoke, kəjdəkajde həbajəke; na ani bam mo.

\section{4. Translation of VI. 1.26}

The child (that) even after he-was-lost, they-got [-him].

One man's sons (were) two. The younger child, for his part, to his father said [-to-him] : "Father, give-me my due goods [as for them]". His goods he-divided-to-them. Not many days only after that, his younger child [for his part] collected his goods altogether, he-departed (and) to a far country he-went. There he-went (-and) -squandered his possessions as he went (and) lived in great style. Inside that country a great famine broke out. To a certain man of that country he-went (and) entered-his-service. That man ordered-him to his garden as his pigs' guard. In order to fill his belly even the refuse intended for the pigs' fodder made his mouth water, but not one man gave (it) to him. After that he came to his senses (litt. : his body's thoughts came- (and-)

23 In the $3^{\text {rd }}$ p. dual! More logical, in our eyes, would have been the $3^{\text {rd }}$ p.sg.

24 Dialect form for ikajdole = jekajdole; cf. II. 1 and II. 3.

25 Dialect form for mowdəjende; cf. II. 1 and II. 3.

26 These translations, though not completely litteral, follow the Sentani text as closely as is possible without doing more violence to English idiom than is necessary for the purpose. Words between ( ) do not occur in the Sentani text but must be supplied in English; those between [] do occur in the original but are not needed in English. 
dwelled-in-him), (and) he says: "So many (are) my father's servants (who) went- (and-now-) take food in quantities; (but) I here have-come(and-) perish from hunger. I shall-rise in order to go to my father's presence (and) to my father I-shall-go- (and-) say [-to-him] : 'Father, I wrong I-have-done [-him] to God, (and) I-have-done [-thee] to thee; thy son [even] to me do-not-say [-to-me], thy servant [though] call-me'." He-rose (and) to his father's presence he-went. (While) he (was) still far-away [even], his father saw-him, he-ran towards his son ['s person], he-took-him, kissed-him [the nose], (his) heart filled(litt.: hung-) him (with) love. That child to his father says [-to-him]: "Father, I have done wrong to God and to thee, don't call me thy son". But his father to his servants says [-to-them]: "Quickly bring hither the finest clothing (and) come-clothe-him, stick [-him] rings on his hand, (and) come-put-on-him footwear. A fat and round [and] pig take (and) come-slaughter. Let-us-eat (and) let-us-make a feast. (For) my son, [even] after he-went- (and-) had-died, came- (and-) has-comeback-to-life, [even] after he-went- (and-) had-got-lost, he-came- (and-) has-been-found." Finally they-ate (and) made a feast.

His elder child, for his part, had-gone-to-stay in the garden. (When) he-went-back to the house (and) came-near-home, people (who) [just] are-making feast he heard. A slave he called [-him], (and) he askshim: "This thing, [just] what (is it) they-are-doing ?" That servant [though] says-to-him: "Thy younger brother [just] has-come-home, (and) thy father has [even] killed a fat and round (and) pig, because he-has-seen-him (-back) sound-and-well." His (i.e., the) elder child became angry, inside he-did-not-go, he-stayed (where he was). Therefore his father came-down (and) came-made-him a kind speech. But to his father he-says: "(Thy) thought must dwell-in-thee (i.e., thou must think); [just] these [so] many years [I] to thee only have-Ialways-obeyed- [thee-] -till-now, I have-not-spoken once against thy word, but thou hast-not-given once even a small pig's young to me, (so that) I and my young friends [we-] make a feast. But thy (other) son (is) hardly here, (who) had-gone- (and-) squandered thy possessions on light women (and) girls, then thou-hast-killed-for-him a fat and round (and) pig." His father says-to-him: "Son, thou with me we just have-always-stayed (together), my own possessions (are) [just] thine. Let-them-make merry, (for) thy younger brother, even after he-went(and-) had-died, he-came-home- (and-) has-come-back-to-life, even after he-went- (and-) had-disappeared, he-came- (and-) has-been-found (-again)." 


\section{5. Translation of VI. 2.}

Jakali of $\exists$ balə (village) and Ajokoj [and].

Jakali of $\exists$ bala (village) came from Buwaj village, (and) he came (and) stayed in Ohej village. He (was) the grown-up sister's child (of Dasim Kəlawbew).22 Once upon a time his mother's brother told-him to go over (and) cut (litt., he-will-go-over, will-cut) for his uncle jokoluwej falom (on) the shore of the village's water-passage. Jakali went, cut off the head of his uncle's dog, loaded it (in a canoe), (and) came-back (with it). He went over to his uncle, (and) says-to-him: "Uncle, that dog's head just mentioned (is) there, I-have-cut- (it-) off, have-loaded (it), (and) come-back (with it), in the canoe." Dasim Kəlowbew was (litt., became) startled: "Oh! how (is) that! Hondombi 27 I-said-to-thee, thou (art) just a fool, a dog thou wentst (and) killst." Other men he-told [-them] (and) they-went-over (and) buried the dog.

Another time his uncle says-to-him: "Go-over, thou-wilt-tear-off banana leaf (and) wilt-bring (-it) -back." Jakali went, cut (and) cut a banana leaf to little bits (and) scraps (and) came-home (with them). To his uncle he-says [-to-him] : "Uncle, that (is) that banana leaf just mentioned." His uncle had hardly taken (it), (then) he felt the banana leaf scraps. "This (is) for what ?" Jakali says-to-him: "Uncle, that banana leaf thou-saidst-to-me, that's it". - "Take (and) go-throw-itaway in the water; (is) this (good) for tobacco (i.e., cigars) when they-use-to-roll (it) ?". Jakali went- (and-) threw-it-away.

Because always-thus only he-acted-up-to-this-time, his uncle ordered [-them] (other) men (and) they-loaded sago (i.e., he ordered others to load sago). (When) day had broken, he-went to the shore. Theyhad-knocked (and) knocked sago, (when) Jakali feigned fever. Shrieks only he-kept-on-shouting. (If) the people hold-him (by) the hand, he (litt., his body) does-not-notice (it). He just continued-shouting shrieks. Ajokoj, Dasim Kələwbew's daughter, went (and) held-him, then only (his) voice was-silent. Every time Ajokoj lets-him-loose, Jakali makes a very loud uproar. Therefore Ajokoj continues-holding-him. That way she just kept-on-doing.

(When) they-had-gone-over to the village, Dasim says-to-them: "Immediately take (and) bring-him-home." Jakali and Ajokoj (and) sat in her canoe. Ajokoj ate food in her canoe. In the evening they-

27 Hondombi (dial.) = jokoluwej falom forementioned; see vocabulary s.v. jokoluzej. Jakali, who came from another village, did not, or acted as if he did not, understand his uncle's words, and thought that joku falom, dog's head, was meant. 
transported Jakali to his own village. Jakali in the middle of the water continued-supporting-himself on Ajokoj's hand (litt.: J.... with A's hand they-two-kept-supporting). (When) they-all-had-disembarked in the village, they-two-went-down the house's nibung-passage, (then) suddenly Jakali embraced-her, shouting: "Hey (people of) $\exists$ bala, (this is) my wife, hey $\exists$ balaans, my wife!" Ajokoj uttered a loud crying and shrieking, a violent crying. The Ohej people went to Dasim Kələwbew (and) say-to-him: "Thy daughter suddenly has-taken Jakali for her [own] husband." Jakali dealt-out-to-them traditional gifts, very sufficiently he-gave-to-them. Dasim's voice did-not-speak (i.e., he was silent). After all (Jakali was) only a nephew through (his) sister, in that way (it was) just sufficient. (In) that same manner the two young people became (and) remained husband and wife (and).

\section{6. Translation of VI. 3.}

Jakali of $\exists$ bala and Hubulew.

One day Hubulew (went) to Ohej village for the claiming of goods. Just (as) he-had-put-off, he-met Jakali of $\exists$ bala (litt.: Jakali theytwo-met-each-other). ${ }^{23}$ Jakali of $\exists$ bala asks-him: "Father, thou (goest) whither?" Hubulew says-to-him: "Father, I (go) to Ohej village to claim goods." Jakali of $\exists$ balo to Hubulew says [-to-him] : "Father, I-shall-await-thee in the Buki." Hubulew went-up to Ohej village. He-went-up (and) by Cape Wajona he landed. (After) he-had-stayedthere a while, they-gave-him the goods, (and) finally he-put-off (and) went-home. (Since) Jakali of $\exists$ bala had not waited-for-him in the Buki, he-put-out (and) went-up to the open water. (After) he-hadgone-up, they-two-met-each-other in the open water. Jakali of $\exists$ balo asks [-him] [to] Hubulew: "Father, those goods did-they-give- (them-) to-thee?" Hubulew says-to-him: "Yes, father, they-did-give- (it-) tome". Jakali of $\exists$ balə says-to-him: "Father, let-us-two-see (it) now." Hubulew took (it, and) opened (it), (and) just as they-two-had-looked, Jakali of $\exists$ balə says-to-him: "Father, let-us-two-throw- (it-) down, will-it-float, the thing?". (i.e., if we throw it in the water, will this stuff remain afloat?). Hubulew speaks: "Who knows?" Finally theytwo-threw, (and) promptly it-sank. Hubulew made a very big uproar against Jakali of $\exists$ balə. After that, though, they-two-went-back to the Buki. (After) they-two-had-stayed in the Buki, they-two-went-off to their own villages; Hubulew to Jawbe village, Jakali of $\exists$ bala to his own $\exists$ balo village. Just as they-two-were-coming-back on the open lake, Jakali of $\exists$ balə to Hubulew says [-to-him]: "Mine, father, mine 
(is) one garden (i.e., I have a certain garden), (which) is-all-the-timelying without seedlings. Wilt-thou-cut (and) wilt-thou-come- (and-) give-me some more hakaj seedlings ?" Hubulew says-to-him: "Father, don't worry; my (own) hakaj seedlings (are) very extraordinary." Hubulew went (and) cut (at) new 28 seedlings, came-back (with them, and) gave [-him] (them) to Jakali of $\exists$ balə. Jakali of $\exists$ balə planted (them) in his own garden, (but after) they-had-come-up, they-kept-onstanding (only); its fruits (were) just not (there).

28 See vocabulary s.v. 


\section{VOCABULARY.}

\section{$a$}

$a 1^{\circ}$ voice, word, order; $a$ few, language (see $f e w$ ); $2^{\circ}$ (the) underneath; $a$ nə, under, beneath: mije $a$, light woman; menkə $a$, light girl

$a$ - $a$-bo-, take (up), carry, load, transport; $a-n u-$, arise, stand up, behave oneself; 2 - $+a-n u-$, go (and) stand up

$a d a j=a j d \varepsilon j$, q.v.

ade- ade-ko-, embrace (each other); $a d e-b o-$, id. (medial); fo- + adeko-, go over (and) embrace (each other)

adila- gather, collect; adila-hi-, id. adunə- connect, close, shut ; adunə$k o-$, id.

$a^{\prime}$ fa father's brother

ahakaj, ahakaj snake (poisonous); see also dami

'ahaw far, far-away

ahe- remove the husk or shell (e.g., of a coconut); ahe-ko-, id.

$a h i$ offence, breach, trespass; ahi alo-ko-, speak in offence, speak against, offend

ajdej father (vocative); thy, your father

aje bird; aje bum-bum, butterfly aje- pinch, jam, clench; aje-ha-, id.

ajom crown-pigeon $a k a$ elder brother; $m \varepsilon-k a, n \varepsilon-k a$, see Gr. III. 3. 2; $a k a-b \varepsilon k \partial$, relatives

akaj interj. ha!

$a k a^{\prime} l a, a k \partial^{\prime} l a$ forest, jungle

akaw branch (of a tree)

akə- bite; akə-bo-, id.

akalo- akalo-ko, to warm, heat, bask (in sun or heat)

akənə- hack, cut, chip, mince;

akano-di-, hack upwards

$a k o$ old man, father; $m \varepsilon-k o, n \varepsilon-k o$, see Gr. III. 3. 2

ako- descend, climb down; ako$b o-$, id. ; $o-+a k o-$, descend down alam bird's tail

alo- alo-ko-, make one's way to, set out for, continue one's way

alu wind

am not; see also bam

ama a lie

ama-ama for show, in appearance, sham; amə-amə moko-bo-, do as if, feign

amum dumb, mute

ana mother (vocative), thy, your mother; wife's mother, motherin-law; mother's sister

an(a)- partake of (food or drink), eat; $a n(\partial)-k o-$, eat; $a n(\partial)-h i$, drink; anə-ə-, go on eating, stay eating ; mə- + anə-ko-, come-eat ani fruit ankej ear 
anu living room in the house aw space for storing things

awa a species of tree (=webo, q.v.) awaw mother's brother aw(ə)- $1^{\circ}$ row, paddle; awo-ə-, row away; awə-mə-, row hither, row back, row home; $2^{\circ}$ peel, flay, skin; awa-bo-, id. $a w b a(n) k \partial$ cassowary

\section{$b$}

$b a \quad 1^{\circ}$ just, only, a little; $b a m-b a$, not little, exceeding $(l y) ; 2^{\circ}$ trace, vestige

bada- bring together, unite, combine; bada-ko-, id. ; fo- +-bada$k o-$, go over (and) combine baka shoulder

bala- $1^{\circ}$ plunge, dive; $2^{\circ}$ bala-ha-, open, unpack, unfasten

bam not, hardly; without; no good, bad; $b a m-b a$, see $b a$; $b a n-k a$, empty, emptiness, hollow(ness) bamo only, just; see $b a$ and $m o$ be two

$b e$ - turn, return, repeat; be-o-, (re)turn down; be-ho-, turn off, away, use up; ma- + be-ho-, come (and) turn off

bele that, those; bele na, (in) there, therefore; bele $d a$, thereafter, after that; bele $j \varepsilon$, but, however

benam twice, once more, again $b_{\varepsilon} 1^{\circ}$ hardly, just; $2^{\circ}$ song, sing-

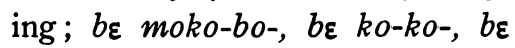
wE-, sing songs

$b_{\varepsilon-}$ seek, search; $b \varepsilon-h o-$, seek forth $b \varepsilon b \varepsilon-$ hew, slash, hack repeatedly $b \varepsilon^{\prime} d \partial$ thigh $b_{\varepsilon j d a}$ pteropus; $b \varepsilon j d a$ fala-fala, bat

$b_{\varepsilon}{ }^{2} \partial$ this, these; $b_{\varepsilon} k \partial$ na, here benso a fly

bo face

bo- bo-ha-, spread out

balaw the areca or betel nut; balaw-sabakaj, areca-and-tobacco, i.e., the betel quid

bale $=j \varepsilon l e$, q.v.

bəna old; bana-fa, elder, eldest, child (of a family)

bana thought, idea; $u$ bana, idea, ruse, senses

bo bone

bo- knock, strike; bo-hi, steer (a canoe)

bobo hard

bodo- hear, listen; bodo-bo-, listen, understand

bohe bamboo

bohi point, cape, headland

bolu seedling; ada bolu, id. (see also $\partial d a, \partial h a$ )

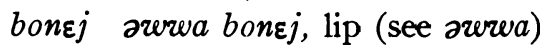
$b u$ water; $b u$ aj $n a$, in the middle (litt.: the inside) of the water; bu moko, the open water (cf. moko) ; nima bu, milk (cf. nima); $d o j b u$, sweat (cf. $d o j$ )

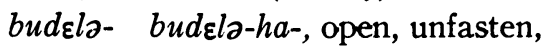
unpack

buhi sort, kind; aha buhi, (some) sort of thing; aha buhi bam, not a thing, not the (right) sort of thing

buhe love

$B u k i$ straits, name of a narrow canal or strait in the Sentani lake between an island and the main 
shore (see also $b u$ and $k i k i$ )

buko na buko da, to his presence, before him

bula (ear)hanger, pendant

bulहnde navel

buli $=k a w ; k a w-b u l i$, very mad

bulu hole; joj-bulu, nostril, nose (see also $j o j$ )

bulum (air) bubble (in water); see also malali

bum fat

bum-bum see aje and aha

buma up, above; buma do, upwards; buma $d a, 1^{\circ}$ from above; $2^{\circ}$ violently (as of a fright)

\section{$d$}

da $1^{\circ}$ postpos. from, out of, by; $2^{\circ}$ see $d a j \varepsilon$

$d a$ - lay, place; $d a-h i$, lay, place with, on; direct to ; ka'la da-hi-, utter a shout at

$d a^{\prime} b a$ wall, partition

$d a d u \quad$ (dial.) $=$ fa'la nana, q.v. dahe dahe nə (dial.) = maka na, q.v.

daj daylight, daytime (as opposed to the night)

daka this, these; daka na, here dakə- wait (for), await dalo $1^{\circ}$ star; $2^{\circ}$ year damo chopping knife damo- handle, finger, touch, feel dami snake (in general; see ahakaj)

dan top, over, above; dan na, in top, above, over; dan $d a$, from above

dano- jerk, pull, draw, drag; dano- $k o-$, id.

dawa- open, loosen; dawa-bo-, id. (medial)

de postpos. with, belonging to, of (possessive); and

$d e-d e-k o-$, sink (something), drive, penetrate into (something)

dejmaj feast

dele old (of men; see also male and nale)

dene morning

denijaj, dinijaj night

$d \varepsilon(j)$ see $d a j \varepsilon$

$d \varepsilon m$ see $d a m$

$d a$ postpos. to, towards, for

$d \partial j \varepsilon, d a, d \partial, d \varepsilon(j)$ pron. $1^{\text {tt }}$ p.sg. ; see Gr. III. 3. 1

dala see doboni

$d a m, d \varepsilon m$ a paddle, oar

damo tail (of animals other than birds)

daw sprout, shoot, young leaf

dawbahi-dawbahi one side and the other, here and there, hither and thither

daw(a)- see dow(a)-

di interj., short form of dika; waj $d i$, see $w a j$

dika that, those, yonder; dika na, yonder

dila- pour (of liquids), stream

dilo- dive; dilo-bo-, id. (medial); dilo-ho-, dive over

dima- weep; dima-ko-, weep about something

do $1^{\circ}$ man; do-mije, man-andwoman, men-and-women, people; human being(s); $2^{\circ}$ name; $3^{\circ}$ egg doboni customary goods, traditional gifts; doboni-dala, id. 
dodo- stab, spout (as of water from a pipe or source); dodo-bo-, id.; fo- + dodo-bo-, proceed to stab

$d o j$ heat (of sun); doj san-sam, burning of heat; see also han(a)-, ham-

dojaw nephew; emsm dojaw, nephew through husband's sister doko time, turn; doko ambaj, once (upon a time); doko $j \varepsilon$ doko $j \varepsilon$, again and again

dom particle as for..., for the part of ..., for one; hokolo-fa $d o m$, as for the younger child dow(a)-, daw(a)- take, receive, get; dowa-mə-, bring home; ว+ dowa-, go-get

$d u$ breadfruit (tree)

duka stone

duka-duka thick, massive

dula- wrap up, pack; dulo-ko-, id. dundum fat, thick

$d u w(\partial)-$ drop, fall, sink; duwə-o-, drop, sink down; je-+duwə-, emerge, come up-out (and) drop; ma- + duwa-, come down, descend (e.g., from the house, which stands on poles) ; $0-+d u w z-$, descend (and) drop

\section{e}

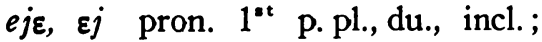
see Gr. III. 3. 1

ele- go through, come through (a hole), enter ; $j e-+e l e-b o-$, climb (and) come through; je-+eleho-, climb (and) go over into eme, emeho (forest-) kangaroo; see also hamoj

emєm husband's sister, sister-inlaw

enclo ghost, spectre, phantom

$\varepsilon$

$\varepsilon j$ see $e j \varepsilon$

$\varepsilon^{\prime} k u \quad$ (dial.) $=u^{\prime} k a$, q.v.

ว

ว- go, go away; ə-ə-, go away; ə-di-, go up, climb

abaw tortoise

ada $=$ aha, q.v.

adə- see, look; ada-bo-, id. (medial)

$\partial d \partial j$-madəj invisible, unseen aha $1^{\circ}$ thing, object; aha bumbum, things, traps, belongings; oha kaho, see kaho; $2^{\circ}$ fever shakaj = ahakaj, q.v.

o'hamam food (cf. aha and an(o)-) a'han(a)jala rations, provisions, victuals (cf. aha and an(a)-) aho (dial.) $=$ kendo, q.v.

o'ho heavy

ahi, $h i$ other

aj inside, middle; $a j d a$, from inside; $a j n a$, (in the) inside, in the middle

ajdaw (direction of) the waterside, the lake's shore

ajsihi hissing sound or noise a'la skin, peel (of fruits)

alo fence, hedge

ala- speak, say; ala-ko-, speak (words), say (something); na $a$ 'alaj, his voice does not speak, 
i.e., he is silent

am banana

$a m^{\prime} b a$ where?

ambaj one; alone; ambaj na, together, at the same time, at once ambele postpos. together with, near, by ; da-mbele $=d a$ ambele, by me, with me

ambe (dial.) $=$ bele, q.v.

ama whole, all, entire; ama-foma, entire(ly), total(ly); (na)nama na, (na)nama-foma na, in (its) entirety, entirely

amansa lance, spear

andi (dial.) $=d i k$, q.v.

arewa mouth; arewa bonej, see bonej

$$
\text { f }
$$

$f a$ child; hokolo-fa, younger, youngest child (of a family); bəna-fa, elder, eldest child

jaja- arw-faja-, see haja-

fako- fako-bo-, float

falam head; jokoluwej falam, see jokoluwej

fare valley

few tongue; $a$-few, language (see a)

$f_{\varepsilon}$ leaf; $m \partial-f \varepsilon$, handpalm

fo $1^{\circ}$ fear; fo bam wali bam, without fear, without life, i.e., impudent and careless; $2^{\circ}$ (dial.) $=$ postpos. $d a$ after $w$

fada- aw-fada-, see hada-

fadalo cockroach

fa'la bow (-and-arrow); fa'la na-

$n a$, bow ; fə'la $u j$, arrow, shaft; fa'la do, warrior; isam-fa'la, war fala a species of shellfish fala-fala (in) scraps, little bits fali forehead

fam even, so, just, some; fam bale

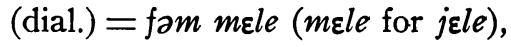
some more, a little more

fi sago

$f i j \varepsilon(-f i j \varepsilon)$ thus, so, in that manner fo- go over, go across, cross, traverse (particularly the waterpassage between the village, which stands over the water, and the shore)

fofo short

foj good; foj-moj, very good; $u$ foj, see $u 1^{\circ}$

fokam $=$ fofo, q.v.

folo- cut, hack; folo-ko-, id.; folo$b o-$, id. (medial) ; folo-di-, cut upwards

foma coconut-rat

foma-foma light (not heavy)

foma see ama

fona day before yesterday

\section{$h$}

ha $1^{\circ}$ (dial.) $=o^{\prime} k i$, q.v. ; $2^{\circ}$ cord $h a-$ ha-bo-, take along, accompany, conduct; $0-+h a-b o-$, go down (and) take along

habakaj tobacco

habana head cover, made of tree bark, worn by the bride whom it is forbidden to see

habo- beat, strike; a-habo-, gobeat; mə-habə-, come-beat

hada- direct oneself to, bear down on; hada-ko-, id. 
hada- laugh; hada-ko-, laugh at haje-, haja- haja-ko-, loosen, let loose, let go ; haja-bo-, squander ; o- + haja-bo-, go-squander

hajsaj red

haka see mu

haka- haka-bo-, run (away)

hakalu see odo

hako sorrow

halo see olo

ham noise, uproar

ham- see han(a)-

ham-fa'la (dial.) = isam-fa'la, q.v. hamoj plains' kangaroo (see also eme)

han(o)-, ham- burn, bake, fry, roast, grill ; han (a)-bo-, id. (medial) ; cf. also hon (a)- (?)

haws- haws-ko-, load, store; hawsbo-, embark (in a canoe)

he (stone) axe

he- hang; he-bo-, hang (intrans.), break (of day); ja hewboke, day broke; he-di-, hang up, dawn, break (of day)

hebela- run

hejsede scattered; hejsede hijohijo, scattered all around, everywhere

heke garden, field; $n \varepsilon j$ seke, his own garden

hele crying, weeping

hele- kindle, set afire; hele-nu-,

kindle self, take fire, burn (intrans.)

henkEndu mosquito

$h_{\varepsilon j}$ beard; $h \varepsilon j-s a k a$, chin

habo- stand; habə-a-, go on standing

hada- die; hada-ho-, id.; a- + hada-, go-die

hahaj side

hakaj an edible species of tuberous plant (Malay keladi)

haki high, long (both of time and range)

$h \partial^{\prime} l \varepsilon-h \partial^{\prime} l \varepsilon$ thin (of objects)

halo just, right real; very, much; na-hala, justly, rightly; justice halam $1^{\circ}$ much, many; halan nam (for halan ham), so many; na halam mele, in great quantities; $2^{\circ}$ see $m a$ and odo

ham $=$ fam, q.v.

hama see odo and cf. dama

handambo a species of tree (Malay bintangur)

$h i=$ ohi, q.v.

hida- hida-ko-, put on, clothe;

ma- + hida-ko-, come-clothe

hijaka bird of paradise

hijo-hijo see hejsede

hikali straight

hike frog

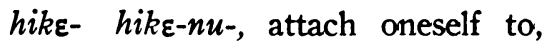
enter service of ; $\partial-+h i k \varepsilon-n u-$, go (and) enter service of

hiko- swim

hikoj-sakoj tired out, exhausted

hila- hila-bo-, be silent

hilo- watch, spy on

him cold (adj.) (of atmosphere)

himi bad

hina who?

hina- ask, question

ho (dial.) $=k o$, q.v.

ho- strike, slay, kill ; ho-ko-, id.;

ho-bo-, id. (medial), slaughter

hoboj top (as of a tree)

hodo throat, neck 
hodo- struggle, fight; compete hoki bracelet

hokolo young; young person; hokolo-fa, see $f a$

holoboj sack, carrying net

homunka mountain

hondombi (dial.) $=$ jokoluzej falom, q.v.

hona- roast, burn (trans.)

hono- lie; hono-a-, go on lying; hono-hi-, lie upon, jump (upon) howaka fibrous bark or husk of coconut

$h u \quad \operatorname{sun} ; h u j \varepsilon h u j \varepsilon, j a j \varepsilon j a j \varepsilon$, day in, day out; see also $j a$

huba- feel; huba-ma-, still feel

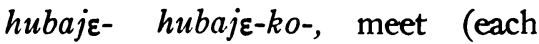
other)

huhu blunt

hulu waterplants, weeds

hundam a support, a prop; base, basis; hundam ko-, use as support

hunə- $1^{\circ}$ sniff, smell, kiss; $2^{\circ}$ huno-ko-, to swallow

huwe evening, late afternoon; nahur'e, in the evening, to-night, at night ; mana hure, see mana

huwa- tell, notice; huwa-bo-, notice, feel ; huwə-ko-, tell (a story)

$i$ fire

$i$-, $i j-$ see $j e-$

ibo idoko ibo, tears; cf. idoko

$i d_{\varepsilon}$ knowledge, knowing; $i d \varepsilon$ am, not knowing, unknowingly

ida'ha tooth

Verh. dl. 47 idoko eye

idoku slumber, sleep; idoku na

nə-, stick, i.e., drop into a slumber $i^{\prime} f a$ (small) canoe for men; kaji$i^{\prime} f a$, canoe (in general); see also $k a^{\prime} j i$

'ikala anger; ikala ko-, make anger, i.e., be, become angry

ikala- ikala-bo-, catch, hold, hold

on

ime house

ima-ima dream(s); ima-ima nana-

li, id.; ima-ima nanali bewoke, he fell to dreaming; see also nanali and be-o-

imoli stern (of canoe)

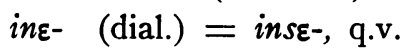

inse- inse-ko-, break, splinter (as wood)

inse (m)bu nasal mucus, snot isa thorn

isam anger; isam-fa'la, see fa'la isanka'la bad, malicious (cf. isam) $i$ 'so shore

isom fool, nitwit, nonentity

iwakoko wild (forest) hen

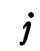

ja $1^{\circ}$ day (light); $h u j \varepsilon h u j \varepsilon, j a$ $j \varepsilon j a j \varepsilon$, see $h u ; j a$ hewboke, day broke (see he-bo-); daka ja, mana $j a$, to-day (see daka and mana); $2^{\circ}$ rain; $3^{\circ}$ already ja- sink, sag, drop, go down jaba (dry) riverbed, valley jado- take, fetch, bring; jado-ko-, id. ; a- + jado-ko-, go-fetch jahala stomach, belly 
jahi round, fat

jakala clear; Bu Jakala, Clear Wa-

ter, i.e., the Sentani Lake

jakala- jakala-bo-, become clear,

visible, be found

jaku sky, heaven

jam roof

jane- to hide; jane-ho-, hide away jawa-, jawo- accompany, take

along; jawo-bo-, id.; jawo-ho-, take across

$j e-, i(j)-1^{\circ}$ go up, rise; $2^{\circ}$ give;

je-ko-, id.; je-bo-, become; ma-

$+j e-(k o-)$, come (and) give; no

$j e-k o-$, breathe, take a breather

(cf. no)

$j e j$ interj. hey!; jej bi, hey there!

jew (coconut) leaf

$j \varepsilon$ emphatic particle; even, just jele postpos. with; and; do jele

mije jele, man and woman, hus-

band and wife (cf. also $l e=d e$ )

jo firewood

jali-jali crooked, curved

jo village, country; jo-kiki, see

$k i k i$; jobo, see obo

joj nose; joj-bulu, see bulu

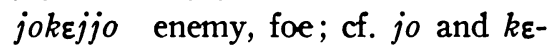

jokoba island

jokoluzej the main rib of the co-

conut leaf; jokoluwej falam, the

head (i.e., sheath) of the main rib

(which is used for making fire) jokonim smoke

joku dog; obo-joku, animal (litt.:

pig-dog, see $o b o$ )

jomo point (as of a weapon)

$j u \quad 1^{\circ}$ sugar cane; $2^{\circ}$ fat (subst.);

$3^{\circ}$ sweet

jum sleeping mat $k$

$k a$ fish

kabam big, great, fat, full-grown

kabe- make (a) mistake(s), do

wrong, ill-treat; kabe-ko-, id.;

(u) nabam kabe-ko-, commit a

$\sin$

kabija entrails, intestines

kabuluw(a)- wrestle

kadu cheek

kahebzj a species of fish (Mal. gabus)

kaho low (of level of stores in a container), empty

$k a^{\prime} j a$ guard, watch; $k a^{\prime} j a$ həbə-, stand guard, keep watch

$k a j e-, k a j(a)-k a j e-k o-$, split, cleave, burst, break (a stone or bone)

kaje a claim, a demand, the collecting (of a debt)

$k a^{\prime} j i$ (big) canoe for women (and children); $k a, j i-i^{\prime} f a$, see $i^{\prime} f a$

kajkulum crocodile

kala a species of shellfish

$k a^{\prime} l a$ a shout, cry, shriek

kala- recover, heal (of sickness)

kala-kala dry

$k a, l a-k a^{\prime} l a$ ma $k a l a-k a^{\prime} l a$, finger;

odo kala-ka'la, toe (see also ma and odo)

kalo $=$ kaho, q.v.

kambi neck

kambu root

kamə- kamə-bo-, tear (off), tear up

kana- look up (at), look upwards

kani earth, ground

kani-kani = kan-kam, q.v.

kan-kam torn to shreds, small 
pieces, scraps

kele space under something (as

under the house on poles); kele

$n$, in that space; under, below

kele-kele lean, thin

kele- show, point out; kele-bo-, id.

$k \varepsilon$ rattan

$k \varepsilon$ - throw; $k \varepsilon-h i-$, throw away;

o- $+k \varepsilon-h i$-, go-throw away

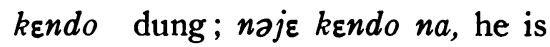
doing his needs

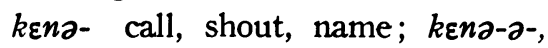

go on shouting

$k \varepsilon w-k \partial w$ wide, broad

kado-nala (family) goods, possessions

$k_{3 j} j \partial-$ climb, come up, grow (as of plants); $j e-+k \partial d \partial j-$, rise up, come up, emerge

kəjnahu, kəjnchu urine

kale- suffer, perish

kalan-kalam dry

$k$ a'lawmom white

$k a l i$ four

kalu son; kalu fa, id.

kama vagina

kəna heart, kernel; kana nə, (have) in mind, (be) up to

kandim small, little

kaze strange(ness), foolish(ness), mad(ness) ; kəw we huwə-, regard, consider something strange, inexplicable, mad ; cf. huwa-

$k i \quad 1^{\circ}$ saliva, spittle; $k i$ ho-bo-, to spit (cf. ho-); ki o-, make the mouth water; $2^{\circ}$ deed, act; $3^{\circ}$ infant; $k i-l o$, infant (boy); $k i$ mije, infant (girl); see $d o$ and mije

kiho sand

\section{kika dark}

kiki narrow(ness), narrow canal; jo kiki, the narrow strip of water between the village, which stands over the water, and the shore

$k i k i-k a k a=k i k a$, q.v.

kili grating, squeaking or creaking noise

kim see odo

ko coconut

ko- do, make, work; ko-ko-, make (something); ko-ə-, go on acting, doing; ko-ho-, id.; ko-mə-, do, act up to now ; $\partial-+k o-$, go (and) behave (oneself), go-do

kodo astonishing, surprising, strange; $u$ kodo, wa kodo, utterly strange (person); see also $u$ and wa

kojde kojde lo, adviser, counselor (lo for $d o$ )

kokum deaf

kolo- treat (to a meal etc.); kolo$k o-$, id.

kolu unripe

koluw(a)- hold (fast)

komonum see odo

kondzw (cleft) coconut shell, husk kowkow reverse side, backside; maw kowkow na, behind the door $k u \quad 1^{\circ}$ thunder; $2^{\circ}$ bracelet kulu-kulu startled, frightened; $k$ ulukulu je-bo-, be startled

kulum $1^{\circ}$ rumbling sound, thundering noise; $2^{\circ}$ things, belongings, traps; kulum wo-, pack up one's things, traps

kumba idoko kumba, blind

kundam passage, corridor; wa kundam, passage made of $w a\left(\right.$ q.v. $2^{\circ}$ ) 


$$
l e=d e \text {, after vowels, q.v. }
$$

$m$

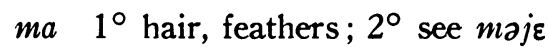
maj $1^{\circ}$ hither $\left(=3^{\text {rd }}\right.$ p. pl. adhort. of ma-, come) ; $2^{\circ}$ disaster, distress; $3^{\circ}$ see $m a j \varepsilon$

maka what?; maka mej, what for?,

to what end?; maka na, why?;

don't worry, no trouble!

male old (of objects); see also dele and nale

malew(-malew) slow(ly)

mala(-mala) soft, weak

malo clothing

mana now; to-day; mana hure,

this evening, to-night; mana ja, to-day

mandilim cold (subst.); mandilin

na ko-, suffer from cold, be cold maw door (opening), doorway, entrance

$m e-1^{\circ}$ go in receding and descending direction (particularly to the waterside, or into a canoe); $2^{\circ}$ see $m e j \varepsilon$

$m e j \varepsilon, m e, m \varepsilon j$ pron. $1^{\text {st }}$ p. pl. excl., see Gr. III. 3. 1

$m \varepsilon=j \varepsilon$ after $m$, q.v.

$m \varepsilon j 1^{\circ}$ due, right; $2^{\circ}$ see $m e j \varepsilon$

$m \varepsilon-k a$ see $a k a$

$m \varepsilon-k o$ see $a k o$

$m \varepsilon l e=j \varepsilon l e$ after $m$, q.v.

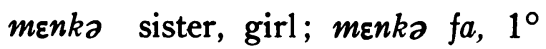
sister's child; $2^{\circ}$ girl-child, i.e., daughter; $m \varepsilon n k a a$, see $a 2^{\circ}$ mo $1^{\circ}$ hand, arm; mo $f \varepsilon$, hand- (palm); ma ha'la(m), elbow ; ma kala-ka'la, finger; ma nink $\varepsilon j$,

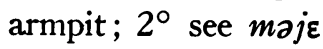

ma- come, come back, come home, go back, go home

ma-be ten

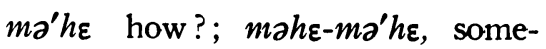

how, some, several

mahambaj five

mahi sadness, remorse

mahina-be seven

$\operatorname{mahin}(a)-a m b a j$ six

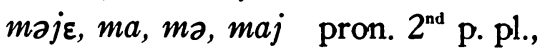
see Gr. III. 3. 1

makaj $1^{\circ}$ manner, way, method; $n \varepsilon j$ makaj = bele makaj (na), (in) that manner, thus; $u$-məkaj, body-, person-manner, i.e., character; $2^{\circ}$ apparently

malali tiny bubbles (in water); bulum malali, bubbles; see also bulum

malem flesh, meat

mala pith (as of sago)

mamalu odo mamalu, footwear

mamam still, yet

ma-naka see naka

mankaj nail

mi flea, louse

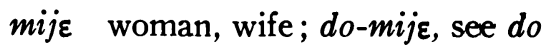
$1^{\circ} ; \operatorname{mij\varepsilon } a$, see $a 2^{\circ}$

mo only, just, once, (with negation) ever

modi-modi refuse, dirt

moj behind, back, after; moj $d a$, from behind, afterwards, thereafter

moj-moj soft, persuasive, kind moko hill, mountain; bu moko, the high water, open water 
moko- make, do; moko-ko-, id.; moko-bo-, make for oneself, act, behave; moko-ha-, do, put, pack into something; ma- +moko-, come (and) make, do

mokodu back (part of body)

molo husband

molo- work on, prepare, fix something; molo-ko, work on (a garden), plant, inter, bury; write; molo-ha-, plant; molo-hi, fix to, hang upon; molo-bo-, become unconscious, lose consciousness

moni hunger; moni maj, famine (see $m a j$ )

mu penis; $m u$ haka, testicles

\section{n}

na, na $1^{\circ}$ postpos. in, on, at; if,

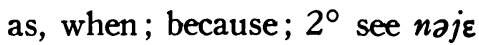
nabe that, those (just mentioned, of before, you know of) na-da thither (with postpos. $d \boldsymbol{d}$ ); na do mo, na do mo, hither and thither, on and on

$n a h i^{\prime} b i$ promptly, suddenly, immediately

nahinki(-hinki) sufficient(ly)

najkaj extraordinary; intense; $n a j k a j$-sajkaj, very extraordinary naka old woman, mother; manakə, my, our mother; nə-naka, his mother

nale old (of women); see also dele and male

nala $1^{\circ}$ nest; $2^{\circ}$ see kada-nala

name three

nanali dream; see also imo-imo nanana low (cf. $a$ ?) nanama(-foma)(na) see ama nawa inter $j$. indeed!, good!

naw'mo warm, hot

naw-we interj. indicating doubt,

who knows! ( $w \varepsilon=j \varepsilon$, q.v.)

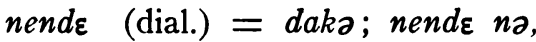

here, now

nezr a useless species of tuberous

plant, resembling hakaj, q.v.

$n \varepsilon(j)$ see $n a j \varepsilon$

$n \varepsilon-k a$ see $a k a$

$n \varepsilon-k o$ see $a k o$

na see na, na

nə- stick, stab; cut; steer, head (a canoe) towards; pick out, knock out (sago pith); hit, afflict (of a disaster or disease); rise, get up (of wind); na-ha-, stick, slaughter; nə-me-, embark, put off (by canoe) ; fo- + no-, go (and) stick etc.; ma- + no-, come-stick

nabam bad(ness), bad conduct (cf. bam?); u-nabam, sin (see also $u$ ) naba $($ dial. $)=$ bele ; naba $d a=$ bele $d a$, q.v.

$n \partial j \varepsilon, n a, n a, n \varepsilon(j)$ pron. $3^{\text {rd }}$ p. sg., du., pl.; see Gr. III. 3. 1

nəkə- sit down, settle, dwell, stay, remain; trans. cause to stay, sit, lie; nəkə-a, go on staying; nəkəko-, stay (somewhere), settle (somewhere); $\partial-+$ nəkə-, go (and) stay, settle; ma-+naka-hi, come (and) sit, settle in something (as a thought in a person)

nəkəhabo crawfish, shrimp, lobster

nala- knead

nali grass, weed

nama $1^{\circ}$ new; $2^{\circ}$ see ama 
na-naka see naka

nibi path, road

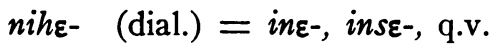

$n i j \varepsilon=n \partial j \varepsilon$, q.v.

nimə $1^{\circ}$ (woman's) breast; nimə

$b u$, see $b u ; 2^{\circ}$ ripe

nimə-nimə (dial.) $=$ hajsaj, q.v.

nimoko breast, chest

nine end, finish; finally, at last,

lastly, after all

ninkaj sweet potato, batata

no $1^{\circ}$ tree (trunk); $2^{\circ}$ tiredness,

fatigue

now odo now, see odo

nobe near(ness)

nobe- nobe-ko-, get near to; nobe-

ma-, come near

nodo wing

no'komom black

$n u k u$ cold (adj.) (of objects)

nulu u nulu, shadow, spirit, ghost, soul; reflected image (as in the water or a mirror); cf. $u$

num hiding, hiding-place

nunde- nunde-bo-, be, get lost, dis-

appear; $a-+$ nunde-bo-, go-disappear

nuw(a)- nuw(a)-bo-, sit, rest; a+ nuw(a)-bo-, go-rest; je- + nuwa-bo-, climb up (and) rest

\section{$o$}

$o$ wood (the material)

$o$ - descend, go down, disembark (from a canoe); $0-0-$, descenddown; o-bo-, collapse; $k i \quad o$-, see ki $1^{\circ}$

obe young men's house

$o^{\prime} b i$ ladder, stairs obo pig; obo kalu, pig's young; $o b o-j o k u$, see joku; jobo (= jo +obo), tame pig; cf. jo odo foot, leg; odo fa, footsole; odo hakalu, ankle; odo ha'la(m), knee; odo hama, heel; odo ka,la$k a^{\prime} l a$, toe; odo kim, calf; odo komonum, shins, odo now, footmark, track

odowalo (dial.) $=o^{\prime} b i$, q.v.

oho- to jump, start, be startled; oho-ə-, jump away; buma da oho-ko-, jump up from fright, give a violent start; cf. buma ojbo $1^{\circ}$ ring; $2^{\circ}$ gerund, $2^{\text {nd }}$ p. sg. and $3^{\text {rd }}$ p.du. adhort. of $o-b o-$; see 0 -

$o^{\prime} k i$ blood

oko moon

oko- pour; oko-o-, pour down; oko-ha-, pour into ole- roll (as tobacco for cigars) olo empty, deserted (of animate beings only); olo-halo, quite deserted; see also $u 2^{\circ}$

olokaka spin

oloku a species of banana; am oloku, id.

omi daughter

ondofolo clan chief, headman $o(n)$ dowaj ashes onko men's house ow (baked) sago cake

$\boldsymbol{S}$

sabakaj see habakaj

saje-, saja- aw-saje-, aj-saje-, an-

saje-, see haje-, haja-

saka see hejsaka and cf. haka 
sakoj see hikoj-sakoj

seke see heke

so $($ dial. $)=$ postpos. do after $w$ or $j$

sala see hala

sokolo see hokolo

\section{$\boldsymbol{u}$}

$u \quad 1^{\circ}$ body, person; $u$ foj, good, i.e., healthy, body ; $u$ foj dowa-, become healthy, recover; $u$-foj, servant, slave, worker; $u$ bana, see bana; $u$-be, fourty; $u$-(a)mbaj, twenty; u-makaj, see makaj $1^{\circ}$; $u$-nabam, bad-, sick-body, i.e., badness, sin; $u$-nulu, see nulu; $u$ kaban do naka-, live to great body, i.e., in great style; nabe $u$, nabe $w a$, the original state, original shape (of something), cf. nabe and $w a ; 2^{\circ}$ empty (of things); $u$ je-bo-, become empty; see also olo

$u-, u w-$ see wa-

ubakə younger brother, sister ube prow (of canoe)

uhe- obey, serve; uhe-mə-, obey up to now

ujaw friend, comrade

$u^{\prime} k a$ cane-grass

uka- cut down, fell (a tree)

$\boldsymbol{w}$

wa $1^{\circ}$ particle then only, just then, just that; $2^{\circ}$ a palmtree (Malay nibung); $3^{\circ}$ skin, hide, bark; nabe $u$, nabe wa, see $u 1^{\circ}$; $4^{\circ}$ see waje wabə- frighten, worry, tease; $\partial-$ + wabə-, go-frighten ; ama wabə-, to lie; see ama wabo depth, bottom (of water) wafe day after to-morrow wafew friend, companion wahe- divide, deal out; wahe-ko-, id.

wahena to-morrow

waj $1^{\circ}$ (direction of the) landside

(as opposed to the waterside; see әjdaw) $2^{\circ}=w a j$ di!, Oh!, woe!; waj di mahe, Oh! how (is) that, What have you done!

waku drum

wale- live; ma- + wale-bo-, come back to life wali life, alive; fo bam, wali bam, see fo

walofo spirit, ghost, God wanəm shape, manner, way; $a$ wanam, like a voice; na wanəm,

(in) that manner, thus, similarly ; aha wanəm bam, not the (right) shape of thing, not the thing to do wankoko (dial.) = iwakoko waw fishing net waw-waw deep we mouse, rat webo a species of tree (Malay pulai)

wena yesterday

$w \varepsilon=j \varepsilon$ after $w$, q.v.

we- we-bo-, dig

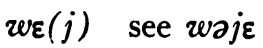

wa- (in some forms $u$-, uw-) $1^{\circ}$ knock, beat, hack; wz-bo-, id. (medial), crack, cleave (a coconut); wə-di-, knock, strike upwards; fly up (of birds); step up 
into, arrive at (the house which wa,la-wa'la quick(ly) stands on poles), pull up, stand walanka fenced-in space, corral still, stop; ma-+-wa-di-, arrive wi river home; $2^{\circ}$ turn the head, look wili lightning round, look up; $3^{\circ}$ (always with wo interj. O!, Hey! obj. affix) say to, tell, order to wo- throw, cast; launch, put out $w_{\partial j \varepsilon,} w a, w a, w \varepsilon(j)$ pron. $2^{\text {nd }}$ p. (a canoe); wo-o-, throw down, sg. ; see Gr. III. 3.1 cause to drop, to sink 
KONINKLIJK INSTITUUT

VOOR TAAL, LAND. EN VOLKENKUNDE

\section{VERHANDELINGEN}

1. H. Terpstra, De Factorij der Oostindische Compagnie te Patani. 1938.

2. E. J. van den Berg, De val van Sora. 1939.

3. C. Nooteboom, Oost-Soemba. 1940.

4. M. A. P. Roelofsz, De vestiging der Nederlanders ter kuste Malabar. 1943.

5. Hadji Hasan Moestapa, Over de gewoonten en gebruiken der Soendanezen. 1946.

6. J. J. Dormeier, Banggaisch Adatrecht. 1947.

7. W. F. Stutterheim, De kraton van Majapahit. 1948.

8. F. S. Eringa, Loetoeng Kasaroeng. Een mythologisch verhaal uit West-Java (Eerste gedeelte). 1949.

9. A. Teeuw, Hariwañśa. 1950. 2 delen.

10. G. Maan, Proeve van een Bulische Spraakkunst. 1951.

11. J. C. Anceaux, The Wolio Language. Outline of Grammatical Description and Texts. 1952.

12. J. Wils, Het passieve werkwoord in de Indonesische talen. 1952.

13. H. J. de Graaf, De regering van Panembahan Sénapati Ingalaga. 1954. 
14. John Bastin, Raffles' ideas on the Land Rent System in Java and the work of the Mackenzie Land Tenure Commission. 1954.

15. Graham Irwin, Nineteenth-Century Borneo. A study in Diplomatic Rivalry. 1955.

16. C. Hooykaas, The Old-Javanese Rāmāyaṇa Kakawin with special reference to the problem of interpolation in kakawins. 1955.

17. P. Donatus Dunselman O.F.M. Cap., Kana Sera. Zang der zwangerschap. 1955.

18. G. W. J. Drewes, Een 16de eeuwse Maleise vertaling van de Burda van Al-Būṣīī (Arabisch lofdicht op Mohammad). 1955.

19. W. Kern, Commentaar op de Salasilah van Koetai. 1956.

20. G. J. Held, Waropense teksten. 1956.

21. H. R. van Heekeren, The Stone Age of Indonesia. 1957.

22. H. R. van Heekeren, The Bronze-Iron Age of Indonesia. 1958.

23. H. J. de Graaf, De regering van Sultan Agung en die van zijn voorganger. 1958.

24. G. W. J. Drewes and P. Voorhoeve, Adat Atjèh. 1958.

25. A. Teeuw, Lombok. Een dialect-geografische studie. 1958.

26. Teuku Iskandar, De Hikajat Atjèh. 1958.

27. H. J. Marks, The first contest for Singapore 1819-1824. 1959.

28. J. Brugman, De betekenis van het Mohammedaanse recht in het hedendaagse Egypte. 1960.

29. E. M. Uhlenbeck, met medew. van J. Soegiarto, Aantekeningen bij Tjan Tjoe Siem's vertaling van de lakon Kurupati rabi. 1960.

30. E. M. Uhlenbeck, Het systeem der Javaanse pronomina. 1960.

31. Jan van Lohuizen, The Dutch East India Company and Mysore 1762-1790. 1961.

32. Han Bing Siong, An Outline of the recent History of Indonesian Criminal Law. 1961. 
33. H. J. de Graaf, De regering van Sunan Mangku-Rat I Tegal-Wangi, Vorst van Mataram, 1646-1677. I. De ontbinding van het rijk. 1961.

34. H. Myron Bromley, The Phonology of Lower Grand Valley Dani. 1961.

35. J. C. Anceaux, The linguistic situation in the Islands of Yapen, Kurudu, Nau and Miosnum, New Guinea. 1961.

36. G. W. J. Drewes, De Biografie van een Minangkabausen Peperhandelaar in de Lampongs. 1961.

37. J. P. K. van Eechoud, Etnografie van de Kaowerawédj (Centraal Nieuw-Guinea). 1962.

38. Tapan Raychaudhuri, Jan Company in Coromandel, 1605-1960. 1962.

39. H. J. de Graaf, De regering van Sunan Mangku-Rat I Tegal-Wangi, Vorst van Mataram, 1646-1677. II Opstanding en ondergang. 1962.

40. C. Skinner, Sja'ir Perang Mengkasar (The Rhymed Chronicle of the Macassar War) by Entji' Amin. 1963.

41. Silvia W. de Groot, Van isolatie naar integratie. De Surinaamse Marrons en hun afstammelingen. Officiële documenten betreffende de Djoeka's (1845-1863). 1963.

42. P. Drabbe, Drie Asmat-dialecten. 1963.

43. S. J. Esser, De Uma-taal (West Midden-Celebes). Spraakkunstige schets en teksten. 1964.

44. J. C. Anceaux, The Nimboran Language. Phonology and Morphology. 1965.

45. H. van der Veen, The Merok Feast of the Sa'dan Toradja. 1965.

46. C. L. Voorhoeve, The Flamingo Bay Dialect of the Asmat Language. 1965. 